\title{
REVIEW
}

\section{Are we working towards global research priorities for management and conservation of sea turtles?}

\author{
A. F. $\operatorname{Rees}^{1}$, J. Alfaro-Shigueto, P. C. R. Barata, K. A. Bjorndal, A. B. Bolten, \\ J. Bourjea, A. C. Broderick ${ }^{1}$, L. M. Campbell, L. Cardona, C. Carreras, P. Casale, \\ S. A. Ceriani, P. H. Dutton, T. Eguchi, A. Formia, M. M. P. B. Fuentes, W. J. Fuller, \\ M. Girondot, M. H. Godfrey, M. Hamann, K. M. Hart, G. C. Hays, S. Hochscheid, \\ Y. Kaska, M. P. Jensen, J. C. Mangel, J. A. Mortimer, E. Naro-Maciel, C. K. Y. Ng, \\ W. J. Nichols, A. D. Phillott, R. D. Reina, O. Revuelta, G. Schofield, J. A. Seminoff, \\ K. Shanker, J. Tomás, J. P. van de Merwe, K. S. Van Houtan, H. B. Vander Zanden, \\ B. P. Wallace, K. R. Wedemeyer-Strombel, T. M. Work, B. J. Godley ${ }^{1, *}$
}
${ }^{1}$ Marine Turtle Research Group, Centre for Ecology and Conservation, School of Biosciences, University of Exeter, Penryn Campus, Treliever Road, Penryn, Cornwall TR10 9FE, UK

Addresses for other authors are given in the Supplement at www.int-res.com/articles/suppl/n031p337_supp.pdf

\begin{abstract}
In 2010, an international group of 35 sea turtle researchers refined an initial list of more than 200 research questions into 20 metaquestions that were considered key for management and conservation of sea turtles. These were classified under 5 categories: reproductive biology, biogeography, population ecology, threats and conservation strategies. To obtain a picture of how research is being focused towards these key questions, we undertook a systematic review of the peer-reviewed literature (2014 and 2015) attributing papers to the original 20 questions. In total, we reviewed 605 articles in full and from these 355 (59\%) were judged to substantively address the 20 key questions, with others focusing on basic science and monitoring. Progress to answering the 20 questions was not uniform, and there were biases regarding focal turtle species, geographic scope and publication outlet. Whilst it offers some meaningful indications as to effort, quantifying peer-reviewed literature output is obviously not the only, and possibly not the best, metric for understanding progress towards informing key conservation and management goals. Along with the literature review, an international group based on the original project consortium was assigned to critically summarise recent progress towards answering each of the 20 questions. We found that significant research is being expended towards global priorities for management and conservation of sea turtles. Although highly variable, there has been significant progress in all the key questions identified in 2010. Undertaking this critical review has highlighted that it may be timely to undertake one or more new prioritizing exercises. For this to have maximal benefit we make a range of recommendations for its execution. These include a far greater engagement with social sciences, widening the pool of contributors and focussing the questions, perhaps disaggregating ecology and conservation.
\end{abstract}

KEY WORDS: Sea turtle · Marine conservation $\cdot$ Evidence-based conservation · Systematic review Research prioritisation 


\section{INTRODUCTION}

The key research question approach has been used effectively to engage ecologists with priority topics determined by policy makers or the researchers themselves (Sutherland et al. 2006, 2009). The approach draws on the knowledge of a broad range of targeted experts to set out their priority questions for the subject matter. The individual questions are then discussed and synthesised to generate a number of priority questions that, if addressed, would have the greatest impact (Cooke et al. 2010). This approach has been used on a range of subject areas, from global conservation and biodiversity issues (e.g. Sutherland et al. 2009) to taxon specific initiatives, such as for sea birds (Lewison et al. 2012) and cetaceans (Parsons et al. 2015).

The status of sea turtles and the need for conservation to aid population recovery have captured the interest of government agencies, non-governmental organisations (NGOs) and the general public, worldwide. This has facilitated increased research focusing on a wide variety of topics relating to sea turtle biology and conservation. However, management actions are often hindered by the lack of data on turtles themselves, human-turtle interactions, turtle population status and threats or the effectiveness of conservation interventions. In an effort to inform effective sea turtle conservation, Hamann et al. (2010) compiled a list of priority research questions based on the opinions of 35 sea turtle researchers from 13 nations. A list of more than 200 questions was condensed into 20 metaquestions that were classified under 5 categories: reproductive biology, biogeography, population ecology, threats and conservation strategies (see Fig. 1). Now, more than 5 years later, we set out to critically appraise the progress that has been made towards informing these key research priorities in this taxon.

\section{METHODS}

\section{Reviewing the literature}

To determine how published research has been focused towards informing sea turtle management and conservation, we evaluated the peer-reviewed literature. We undertook a systematic review using Web of Science (v.5.22.3; 21 June 2016). In order to ensure capture of all relevant texts we used the topic search 'sea turtle' or 'marine turtle' or 'loggerhead turtle' or 'green turtle' or 'leatherback tur- tle' or 'olive ridley' or 'Kemps ridley' or 'hawksbill turtle' or 'flatback turtle' in 'All databases' for the 2 most recent complete years (2014 and 2015), which resulted in a list of 707 articles. We then removed duplicates, spurious hits, generic texts (such as references to entire proceedings) and non-peerreviewed 'grey' literature based on title and abstract, or main text if relevance was unclear from the abstract.

\section{Literature analysis}

For each article, 2 authors (A.F.R. and B.J.G.) independently reviewed and ascribed its application to the original 20 questions highlighted in Hamann et al. (2010). These assignations were compared, and where differences occurred they were resolved through discussion. As a further check, input on the assignation of articles was sought from the other coauthors. Papers were, where possible, classified by sea turtle species and ocean basin.

\section{Expert opinion}

A total of 63 publishing sea turtle researchers were invited to contribute to this initiative. Those that responded positively ( $\mathrm{n}=42$ ) were requested to indicate the 3 most relevant questions in Hamann et al. (2010) that matched their expertise. Based on their indications, they were then assigned to groups of 2 or 3 to compile summaries on recent progress towards answering each of the 20 questions. These summaries were then shared among all co-authors for comment, cross-linkage, internal review and refinement.

\section{RESULTS}

In total, 605 articles were reviewed in full and from these 355 (59\%) were judged to substantively address the 20 key questions in sea turtle conservation and management (Fig. 1 and Appendix). A total of $40(11 \%)$ of these papers cited the Hamann et al. (2010) paper. Papers on palaeontology $(n=21 ; 3 \%)$ were excluded. Publications on fundamental science $(\mathrm{n}=74 ; 12 \%)$ and novel techniques $(\mathrm{n}=36 ; 6 \%)$ not yet linked with conservation or management questions were not included here, although we stress the importance of such work in leading innovation that can underpin significant advancement. Baseline 
What are the factors that underpin nest site selection and behaviour of nesting turtles?

What are the primary sex ratios being produced and how do these vary within or among populations and species?

What factors are important for sustained hatchling production?

What are the population boundaries and connections that exist
among rookeries and foraging grounds?

What parameters influence the biogeography of sea turtles in the oceanic realm?

Where are key foraging habitats?

Can we develop methods to accurately age individual turtles, determine a population's (or species') mean age-at-maturity, ...?

What are the most reliable methods for estimating demographic parameters?

How can we develop an understanding of sea turtle metapopulation dynamics and conservation biogeography?

What are the past and present roles of sea turtles in the ecosystem?

What constitutes a healthy turtle?

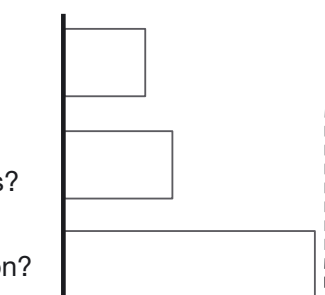

$N=355$

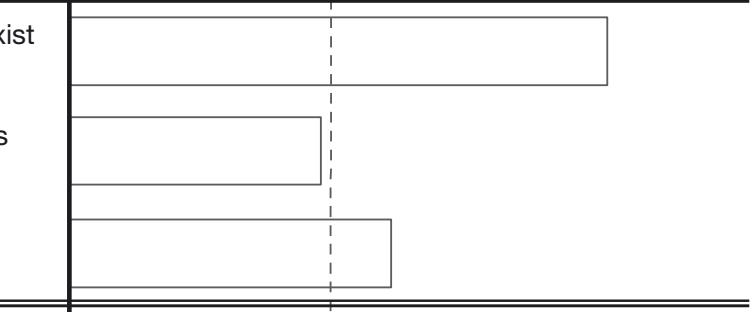

What will be the impacts from climate change on sea turtles
and how can these be mitigated?

What are the major sources of fisheries bycatch and how can these be mitigated in ways that are ecologically, economically ...?

How can we evaluate the effects of anthropogenic factors on sea turtle habitats?

What are the impacts of pollution on sea turtles and their habitats?

What are the etiology and epidemiology of fibropapillomatosis, and how can this disease be managed?

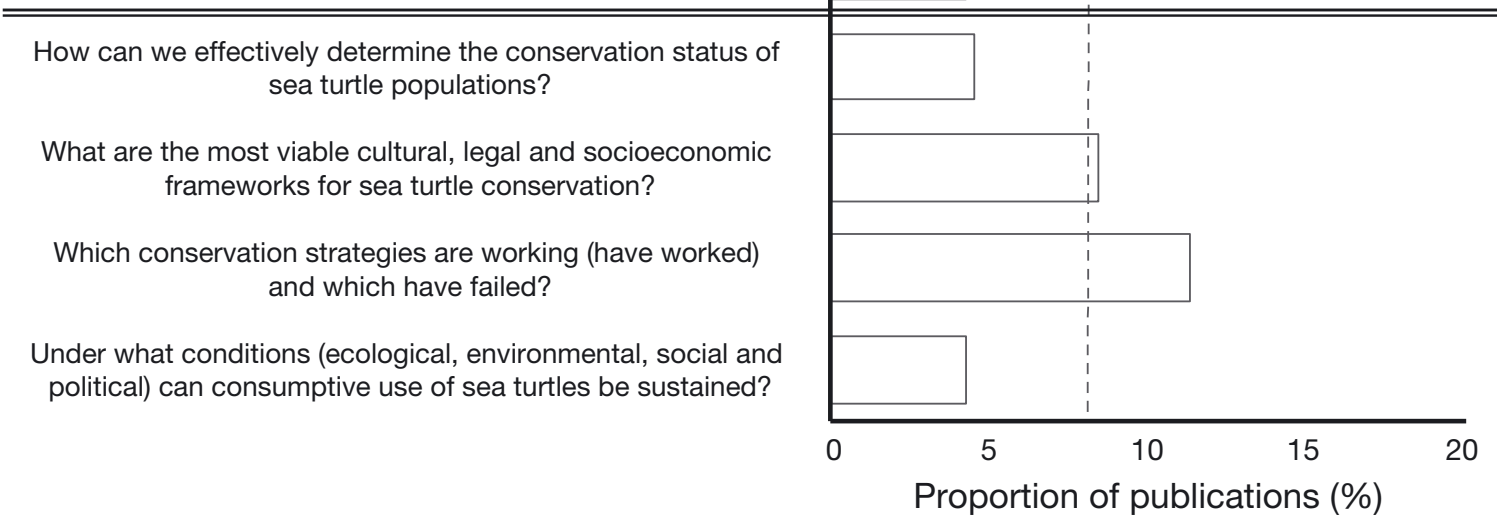

Fig. 1. Proportion of publications from 2014 and 2015 that address the 20 key questions of Hamann et al. (2010). Dashed line represents the mean value of the proportion of publications (8\%). Percentages sum to greater than 100 as some publications covered more than one question 


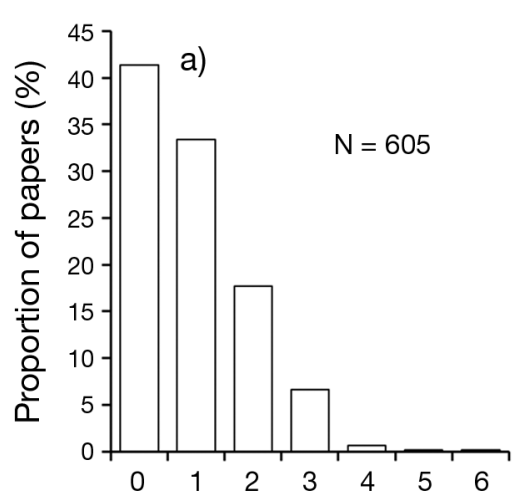

No. of questions addressed
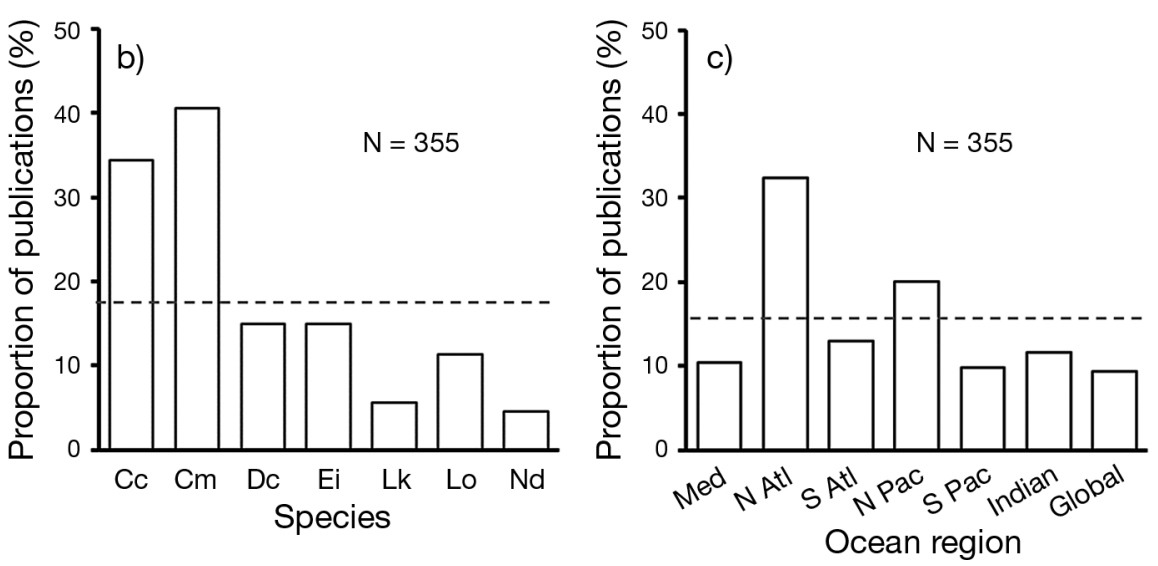

Fig. 2. (a) Proportion of papers addressing the key conservation questions highlighted by Hamann et al. (2010). Prevalence and biases in publications from 2014 and 2015 per (b) species and (c) ocean area. Dashed lines represent mean values. Percentages sum to greater than 100 as some publications covered more than one species. Cc $=$ Caretta caretta, Cm $=C h e l o n i a$ mydas, Dc $=$ Dermochelys coriacea, $\mathrm{Ei}=$ Eretmochelys imbricata, $\mathrm{Lk}=$ Lepidochelys kempii, Lo = Lepidochelys olivacea, $\mathrm{Nd}=$ Natator depressus

nesting monitoring reports that did not include extensive time series $(n=20 ; 3 \%)$, or reports of simple trophic interactions $(n=16 ; 3 \%)$, were further examples of articles that were not included in the final list, although we acknowledge that such data underpin studies of ecology, efficacy of conservation or assessments regarding the severity of threats. A total of 202 papers (33\%) were considered to cover single key questions but $153(25 \%)$ were more broadly scoped papers addressing up to 6 of the questions (Fig. 2a).

\section{Outputs by species, ocean basin and publication venue}

Species bias in published articles was prevalent (Fig. 2b). By far the most common species reported upon were green turtles ( $41 \%$ of articles) and loggerhead turtles (34\% of articles). As might be expected, sea turtle species with more restricted ranges (Kemp's ridley and flatback turtles) featured least, appearing in less than $6 \%$ of the articles (see also Jeffers \& Godley 2016). Geographically, work was biased towards the North Atlantic and, to a lesser extent, the North Pacific (Fig. 2c), possibly demonstrating the great interest and relatively enhanced funding in nations bordering these regions. Sea turtle literature contributing to the key questions was published in over 130 outlets, with the top 6 journals accounting for $32 \%(n=114)$ of all articles (Fig. 3). Three of these are Open Access venues, with the other 3 being leading marine ecology journals.
No. of publications

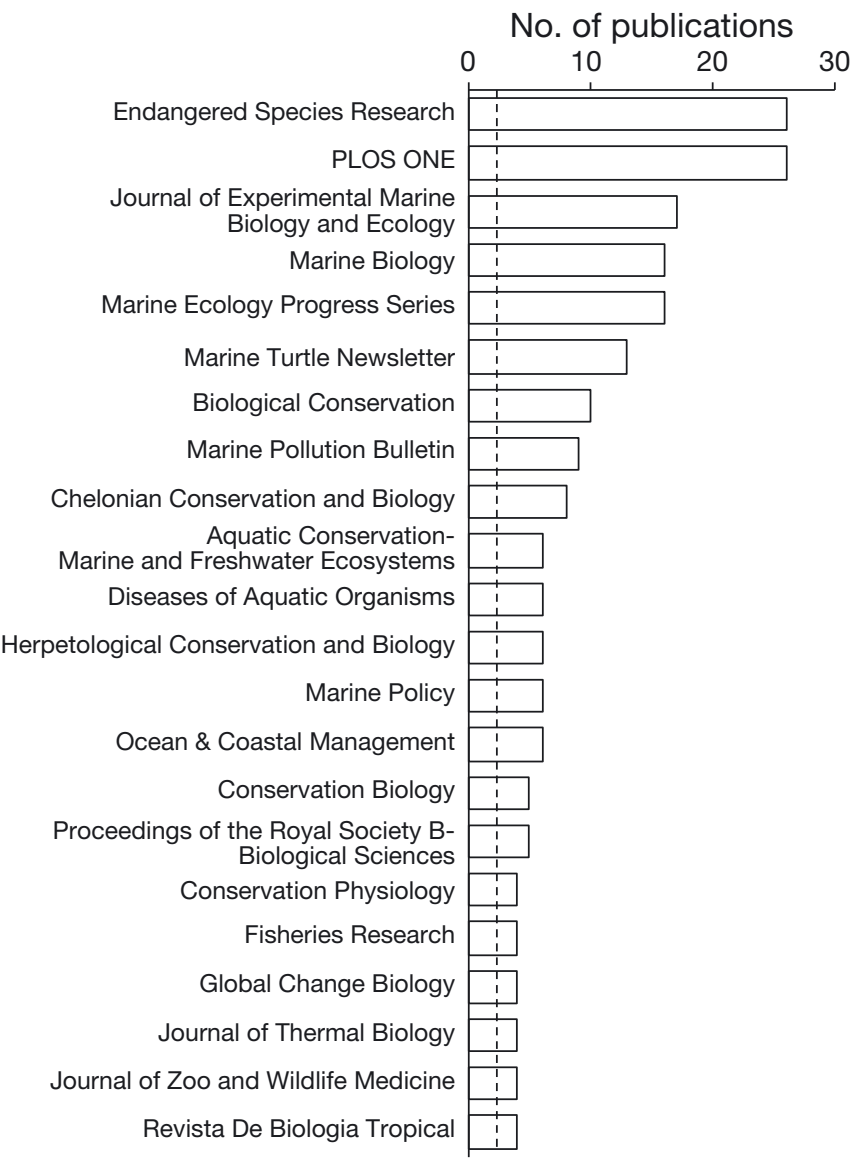

Fig. 3. Frequency of publishing outlet of all sources with 4 or more publications for the 355 articles that were adjudged as describing work that substantively informs sea turtle conservation or management that may be ascribed as contributing to answering the 20 key questions. Dashed line represents the mean value of publications per all publishing outlets, i.e. 2.6 publications 


\section{To what extent are the 20 questions being addressed?}

Progress to answering the 20 questions in the 2 years of peer-reviewed literature was not uniform (Fig. 1). The related questions which extensively utilise modern technologies such as satellite tracking and molecular genetics: 'What are the population boundaries and connections that exist among rookeries and foraging grounds?' and 'How can we develop an understanding of sea turtle metapopulation dynamics and conservation biogeography?' featured most highly (both at $17 \%$ of publications numerically). Eight questions were each addressed in less than $5 \%$ of the literature with those relating to reproductive biology (Q1-3), threats (Q12-16) and conservation strategies (Q17-20) generally the least addressed. The question 'How can we evaluate the effects of anthropogenic factors on sea turtle habitats?' was singly the least represented ( $<1 \%$ of articles).

Quantifying peer-reviewed literature output is not the only metric for understanding research progress towards informing key conservation and management goals. Nevertheless, it is a useful tool with which to determine research output as an indicator of the focus and extent of work valuable to the management and conservation of sea turtles. The following 20 sections present synthesized expert opinion on the actual progress towards answering each of the original key questions set out by Hamann et al. (2010). They reference up-to-date findings together with foundation research carried out prior to publication of the 20 questions.

Q1. What are the factors that underpin nest site selection and behaviour of nesting turtles?

How do turtles decide where and when to lay their eggs? We know the necessary conditions for oviposition and incubation (Mortimer 1990, Ackerman 1997), we recognize that some anthropogenic activities can disrupt nesting (Miller et al. 2003) and have identified that delays to nesting can increase embryonic death (Rafferty et al. 2011, 2013). However, we still lack a deeper understanding of how sea turtles select nest sites at intra- and inter-beach levels. Natal homing has been the predominant explanation for maintenance of populations of turtles at specific nesting beaches (Bowen et al. 2016; see Q4 and Q9), and recent region-level analyses suggest that the interplay of abiotic patterns with natal homing, may also play a role in beach selection, including destructive weather patterns (Fuentes et al. 2011a), access of hatchlings to major oceanic currents for dispersal (Putman et al. 2010a), and variation in the Earth's magnetic field used for geolocation (Brothers \& Lohmann 2015). There may also be local adaptation to specific incubation conditions at the beach level that constrains where a turtle may choose to nest (Weber et al. 2012).

Once a beach is selected by a reproductive female, it remains unclear where along the beach she may emerge to lay her eggs, and whether lateral, spatial proximity to previous nests is the product of a randomized process (Nordmoe et al. 2004, Tiwari et al. 2005). Others have reported that nearshore factors such as wave height and steepness of approach (Yamamoto et al. 2012, Lamont \& Houser 2014) or major beach-strand structures such as vegetation (Reising et al. 2015), buildings and other types of construction (Witherington et al. 2011), and natural or artificial debris (Fujisaki \& Lamont 2016) influence where along the beach females lay their eggs.

Once a female has emerged from the ocean onto a nesting beach, she chooses where to place her eggs relative to the high tide line, dune line, and/or vegetation line. There has been some debate about the repeatability of nest site selection by individual females (e.g. Kamel \& Mrosovsky 2005 vs. Pfaller et al. 2009 and Nordmoe et al. 2004). Recent studies have focused on quantifying nests laid in different beach zones such as open sand, intermediate and vegetation, and/or repeatability of location. Contrasting with lateral placement, most report that the nest locations are not randomly dispersed, and that individual females generally prefer to use the same zone for placing sequential nests in the same season (Neeman et al. 2015a). Interestingly, a multi-season study suggests that while females tended to lay clutches in similar zones in the same season, in other seasons the same females would change zones to lay their nests (Santos et al. 2016). The pattern of non-random nesting at a fine scale (on a given beach) while retaining the capacity to widely vary nest position at a larger scale (between beaches) would seem to be a prerequisite for populations of turtles to maximise hatching success while still being able to respond to environmentally caused changes in the suitability of beaches over time. Individuals with a lower nest site fidelity are needed for the establishment or drift of nesting along a coastline as conditions change. Overall, progress in understanding nest site selection and nesting behaviour has primarily been focused on observational research. While this is valuable for identifying the factors involved in these behaviours, 
a deeper understanding will likely require an experimental approach, by manipulating either the habitat, nesting opportunity or sensory inputs of nesting females. Greater knowledge of these processes, particularly including inter-specific variability, may be critical to informing management decisions related to beach manipulation or beach construction following coastline changes from climate change and sea level rise (see Q3 and Q12).

Q2. What are the primary sex ratios being produced and how do these vary within or among populations and species?

The prevalence of temperature-determined sex determination (TSD) in reptiles (Charnier 1966), including turtles, is still puzzling from a molecular, ecological and evolutionary point of view. Progress has, however, been made. It has been suggested that TSD is a form of condition-dependent sex allocation favoured over genotypic sex determination when incubation temperature influences fitness in a manner that differs between the sexes (Charnov \& Bull 1977). A new hypothesis linking the evolution of TSD with difference in age at maturity in males and females is very promising (Schwanz et al. 2016). Currently, however, we lack information on the age at maturity in sea turtles, although new data are becoming available (see Q7). Although the molecular and cellular mechanisms of temperature on sex determination still remain elusive, it seems clear that activity of the Sox 9 gene is implicated at early stages (Sifuentes-Romero et al. 2013), and that gene methylation is used to lock gene expression after sex determination is complete (Venegas et al. 2016). The Cold-Inducible RNABinding Protein (CIRBP) gene could play an essential role as being the sensor of temperature for TSD in Chelydra serpentina (Schroeder et al. 2016).

Few recent studies have produced primary sex ratio estimates using histology (a lethal method) and most have used a small sample size, during a limited time in the nesting season or only for 1 season, which precludes a correct understanding of primary sex ratio for sea turtles (see Wyneken \& Lolavar 2015 for discussion). A new promising method to estimate the sex of hatchlings based on steroids extracted from eggshell is a non-lethal sexing method (Xia et al. 2011, Kobayashi et al. 2015), but the approach remains to be validated. Many primary sex ratio studies use indirect proxies such as average temperatures during incubation (entire or middle-third) to cover all the nesting season or several seasons. These esti- mates have been rendered possible by the development of new statistical methods to reconstruct the sand temperature from various proxies (Fuentes et al. 2013, Laloë et al. 2014, 2016, Girondot \& Kaska 2015). However, the use of indirect proxies to establish primary sex ratio can generate significant error (e.g. Georges et al. 1994, Wyneken \& Lolavar 2015). Additionally, many studies ignore the difference of thermal reaction norm for sex ratio (Hulin et al. 2009) or embryo growth (Morales Mérida et al. 2015) between populations (Girondot \& Kaska 2014) and more research must be undertaken to produce validated proxies.

Primary, subadult and adult sex ratio have been established for loggerheads in the Mediterranean Sea, and it appears that a gradient in the sex ratio is observed, with a strong female bias for the primary sex ratio (Uçar et al. 2012, Sarı \& Kaska 2015), a moderate female bias for the sex ratio in subadults (Casale et al. 2006), and no bias (White et al. 2013, Casale et a. 2014, Cocci et al. 2014, Stewart \& Dutton 2014) or a male bias (Rees et al. 2013) observed in adults. These findings suggest that demographic or behavioural factors that do not generally reflect primary sex ratio can greatly affect subadult or adult sex ratios, but proximity to nesting areas may contribute to local sex ratio variation (see Q8). Finally, few studies take into account the multifactorial nature of the ecology of TSD. When it has been studied, data suggest that TSD may be more resilient in the face of climate change (see Q12) than originally thought (Fuentes et al. 2011b, 2013, Abella Perez et al. 2016).

\section{Q3. What factors are important for sustained hatchling production?}

Improving the knowledge of factors that influence hatchling production will aid the long-term maintenance of sea turtle populations, especially under changing climate or human-dominated landscapes. In 2010, the theme areas believed to be important were related to embryology and physiology, population-scale data on hatchling production, and developing and evaluating reliable techniques in order to assess hatchling fitness. Each of these areas remain relevant, but only some are well reflected as foci of recent research: (1) abiotic factors influencing embryonic development, emergence success, hatching success, and/or hatchling condition, including temperature (e.g. Horne et al. 2014, Rafferty \& Reina 2014, Lolavar \& Wyneken 2015) and oxygen availability (Cheng et al. 2015); (2) biotic factors that affect 
embryonic development, emergence success, hatch success, and/or hatchling condition, including paternity (Phillips et al. 2013, Alfaro-Núñez et al. 2015) and maternal health (Perrault et al. 2012), microbes (e.g. Sarmiento-Ramírez et al. 2014b, Bézy et al. 2015), insect (Baena et al. 2015) and avian (Burger \& Gochfeld 2014) predators; (3) population or rookery viability and hatchling production in a changing climate (e.g. Laloë et al. 2014, Santidrián Tomillo et al. 2014, 2015; see Q12) and (4) examinations of longterm programmes, policy or management instruments related to improving management of, or maintaining, high hatchling production (e.g. Brost et al. 2015, Fuentes et al. 2015b, Liles et al. 2015, Muñoz \& Arauz 2015, Revuelta et al. 2015b; see Q19). Additionally, more research is required to investigate potential health effects (i.e. abnormalities) caused by contaminants on sea turtle development (Alava et al. 2011; see Q15).

Most research on hatchling production has focused on loggerhead, green and leatherback turtles, and the majority of studies have been conducted on North Atlantic and Pacific turtle populations. In general, the key species gaps are for hawksbill, flatback and ridley turtles, and studies on populations of any species from the Mediterranean, Indian Ocean and South Atlantic regions. These are important species and location gaps; 6 sea turtle Regional Management Units (RMUs) determined to be at highest risk and 8 of the 12 RMUs with critical data needs are in the Indian Ocean, and 8 of the 12 hawksbill turtle RMUs have critical data needs (Wallace et al. 2011). Although there are numerous turtle research and conservation initiatives throughout these regions, much of the data and publications from these regions exist as grey literature (project or governmental reports, etc.) and are not available to a wider audience.

In addition to filling knowledge gaps on population-scale hatchling production for species in these locations, further research is also required to develop and evaluate techniques to assess hatchling fitness, analyse long-term data sets on hatchling production, understand the abiotic factors that link hatchling production to nest site selection (see Q1) and determine critical thresholds for hatchling production for all sea turtle populations or management units. Our predictions of rookery and population viability and the ability of sea turtles to shift nesting locations in relation to human-impacted changes to the environment will be informed not only by measuring hatchling production, but also by understanding the effects of abiotic and biotic factors during incubation on hatchling survivorship and dispersal.
Q4. What are the population boundaries and connections that exist among rookeries and foraging grounds?

Defining the geographical boundaries of cryptic organisms including sea turtles is a fundamental but complex process. Major advances in defining breeding populations have led to a comprehensive understanding of stock structure for most species globally. Perhaps the biggest recent genetic advances have been made in the Indian and Pacific Oceans, for green (e.g. Dutton et al. 2014a,b, Nishizawa et al. 2014b, Bourjea et al. 2015a, Jensen et al. 2016), hawksbill (e.g. Gaos et al. 2016, Vargas et al. 2016) loggerhead (e.g. Nishizawa et al. 2014a, Shamblin et al. 2014, Matsuzawa et al. 2016), and olive ridley turtles (Jensen et al. 2013). Globally, significant advances have been made integrating male- and female-mediated gene flow by incorporating both mitochondrial and nuclear DNA (Dutton et al. 2013) for delineating demographically independent populations. Progress towards increasingly multidisciplinary approaches, where data such as genetics and ocean particle modelling (e.g. Gaspar et al. 2012, Monzón-Argüello et al. 2012, Putman \& Naro-Maciel 2013, Putman et al. 2013), stable isotopes and satellite telemetry (e.g. Zbinden et al. 2011, Seminoff et al. 2012, Shimada et al. 2014, Vander Zanden et al. 2014, 2016), or tracking and modelling (Putman \& Mansfield 2015), have been combined to reveal new information, including about the cryptic 'lost years'.

Nonetheless, researchers continue to identify and fill significant gaps in sampling and to address methodological limitations. There is insufficient information regarding connectivity in flatback turtles, which are still listed as 'Data Deficient' (Red List Standards \& Petitions Subcommittee 1996). Some regions remain less studied than others in light of accessibility, permitting, funding, safety, or other obstacles. Despite recent pioneering work, to more fully understand the boundaries and constraints of sea turtle movements, connections among Management Units (MUs; rookeries) and less accessible juvenile/ adult foraging grounds, and 'lost years' habitats, must be further investigated (see Q5).

New technological advances are increasingly being applied to address these gaps through tracking, modelling, and genomic analyses. Satellite tags are being developed for use on cryptic stages such as small pelagic turtles (Putman \& Mansfield 2015), and high resolution particle models are challenging ideas of boundaries defined solely by passive pelagic drift (Wolanski in press). New DNA sequencing technolo- 
gies are resolving stock structure through whole mitogenome approaches (Shamblin et al. 2012a,b) and short tandem repeats (STRs, Tikochinski et al. 2012). Indeed, the small segment traditionally sequenced stands to be dwarfed by next-generation data. One of the advantages of these genome-wide data, compared to traditional markers, possibly relies on the chance to identify traces of selection shaping population genetic differentiation (Funk et al. 2012). Furthermore, not only will more of the genome be covered, but sea turtle connectivity may soon be approached more comprehensively through environmental DNA (eDNA) sequencing of entire communities from water or soil samples. Although the significant obstacle of international comparisons has been overcome through the widespread adoption of a standardised sequence nomenclature for now, this will continue to be an important consideration in the genomics era. As we reveal the boundaries and constraints of sea turtles, we will better understand the processes leading to these biogeographic patterns. However, we should always keep in mind that boundaries must been viewed as being flexible, particularly in a changing world (see Q12).

Q5. What parameters influence the biogeography of sea turtles in the oceanic realm?

Satellite tracking has continued to expand our knowledge of adult oceanic movements with noteworthy advances in data-sharing and collaborative partnerships that have allowed assessment of the spatial distribution of populations over entire ocean basins, such as for leatherback turtles in the Atlantic, where it has been revealed how individuals target productive areas for foraging (Fossette et al. 2010, 2014, Benson et al. 2011). For oceanic juvenile stages, the last few years have seen a profusion of work using 3 distinct approaches: (1) assessing likely drift patterns for post-hatchlings based on ocean currents, (2) direct tracking of individuals that are large enough (generally $>20 \mathrm{~cm}$ carapace length) to carry satellite tags, and (3) using chemical markers (trace elements and stable isotopes) in the tissues to indicate the likely oceanic foraging areas of individuals.

It is generally assumed that once their swimming frenzy finishes a few hours or days after they enter the water, hatchlings then drift passively, at least in their first months, so that their patterns of movement can be approximated by ocean circulation models or the movement of Lagrangian drifters (e.g. Hays \& Marsh 1997, Hays et al. 2010a, Hamann et al. 2011,
Putman et al. 2012a), although in some cases the limited swimming ability of hatchlings has also been parameterized within these models (Hamann et al. 2011, Putman et al. 2012a, Scott et al. 2012a). Emerging from these studies is a view that the movements of post-hatchlings may shape the oceanic breeding migrations subsequently seen in adults, with adults travelling to foraging sites that they experienced in their earlier oceanic juvenile stage, i.e. adult migration patterns may not be innate but are rather a learned response to an individual's earlier experience (Scott et al. 2014b). Simulated drift of young turtles has also shed light on potential interactions of young turtles with pollutants (Putman et al. 2015a), helped to inform on growth rates (Scott et al. 2012b) and started to reveal how inter-annual variability in ocean currents may impact survival of oceanic juvenile stages and hence subsequent recruitment rates to adult populations (Ascani et al. 2016).

As young turtles grow and their swimming ability improves, these assumptions of largely passive drift become less realistic. There have been a number of landmark studies to directly track juvenile individuals, from $14 \mathrm{~cm}$ carapace length (Putman \& Mansfield 2015) and bigger (Briscoe et al. 2016), as well as ongoing efforts to track larger $(>50 \mathrm{~cm})$ juveniles caught at sea (Dalleau et al. 2014). These studies suggest that even small oceanic turtles may sometimes show movements that are independent of the prevailing currents, presumably in cases where passive drift is not enough to ensure movements to favourable oceanic resources such as temperature and food. A challenge for our understanding of sea turtles and other marine megafauna remains the synoptic assessment of the ocean currents where turtles are located, to better resolve the roles of active directional swimming versus passive drift (Hays et al. 2016).

Chemical signatures in the tissues of individuals sampled once they have settled in neritic sites have started to reveal their previous oceanic habitats. Work on this topic suggests that from a single rookery each juvenile may occupy one of several distinct oceanic foraging areas, and that these areas are shared by multiple rookeries (López-Castro et al. 2013, 2014b, Fujioka et al. 2014a). A goal of future studies will be to see a convergence of the conclusions drawn from these different approaches (current models, direct tracking, chemical signatures), combined with niche modelling approaches (VaroCruz et al. 2016) to provide a more complete picture of oceanic foraging areas for juvenile turtles and how they connect to neritic developmental areas (see Q6). 


\section{Q6. Where are key foraging habitats?}

Multi-disciplinary approaches have advanced our knowledge on the distribution and use of sea turtle foraging habitats. These approaches include telemetry (satellite, radio, acoustic), intrinsic markers (genetics, stable isotopes, trace elements), bycatch, markrecapture (including photo-ID), strandings, aerial and underwater surveys, particle tracking, modelling and behaviour simulation (e.g. Foley et al. 2007, Putman et al. 2012b, Stewart et al. 2013, Dunbar et al. 2014, López-Castro et al. 2014b, Luschi \& Casale 2014, Seminoff et al. 2014, Walcott et al. 2014, Ceriani et al. 2015, Fuentes et al. 2015a, Narazaki et al. 2015, Pikesley et al. 2015, Putman et al. 2015a,b).

While strong focus remains on post-nesting females (logistically more accessible; e.g. Griffin et al. 2013), more studies are investigating males and juveniles (Meylan et al. 2011, Arendt et al. 2012a,b, Casale et al. 2013, Mansfield et al. 2014; see also review by Jeffers \& Godley 2016). Consequently, our understanding of migratory connectivity among breeding, foraging and developmental habitats has improved. This information facilitates the delineation of migratory corridors (Pendoley et al. 2014b, Baudouin et al. 2015, Shaver et al. 2016) and the identification of foraging habitats supporting high genetic diversity for protection (Hart et al. 2012, Hardy et al. 2014, Joseph et al. 2014). While some foraging habitats overlap with protected areas (Scott et al. 2012c, Hart et al. 2013, Revuelta et al. 2015a), others are more susceptible to fisheries pressure (Fossette et al. 2014, Seminoff et al. 2014) or industry (Whittock et al. 2014).

Some foraging habitats support large aggregations of turtles of different species and size/age classes from different populations (Bresette et al. 2010, Vander Zanden et al. 2013, Sampson et al. 2014, Gorham et al. 2014), whereas others support small numbers of individuals distributed across wide areas (Hawkes et al. 2006, Luschi \& Casale 2014). Turtles tend to exhibit high fidelity to oceanic and/or coastal foraging habitats (Goodman Hall et al. 2015, Shimada et al. 2016, Vander Zanden et al. 2016), which, in some places, could be the result of adults and late-stage juveniles retaining high fidelity to known resources after drifting there as hatchlings (Hays et al. 2010a, Putman et al. 2015a,b). However, turtle behaviour is also more complex than previously hypothesized, with many exceptions to traditional life-history models.

Plasticity in the distances travelled to foraging habitats, home range size, and foraging strategy exists (Hatase et al. 2013, Schofield et al. 2013), possibly driven by competition, resource quality or resource availability, predation risk or climatic variability (Stadler et al. 2015, Prior et al. 2016). Our knowledge about movement patterns and interactions within foraging habitats is constantly advancing through the use of high-resolution technologies, including acoustic tracking, Fastloc GPS, ROVs, and camera systems (e.g. Narazaki et al. 2013, Smolowitz et al. 2015, Thomson et al. 2015a,b, Crear et al. 2016). An emphasis, however, is required on understanding resource partitioning and the trophic structuring of turtles at the ecosystem level (Thomson et al. 2015a,b; see Q10).

Ultimately, sea turtles spend most of their lives in foraging habitats, which are fundamental for juveniles to recruit into adult populations (Velez-Zuazo et al. 2014, Colman et al. 2015) and for adults to have sufficient reserves to breed and produce offspring. Thus, future studies must focus on how to assess which are the key foraging areas, including how their distribution and productivity will alter with climate change and impact reproductive output (Pikesley et al. 2015, Willis-Norton et al. 2015; see Q12), in order to prioritise the protection of these key habitats.

Q7. Can we develop methods to accurately age individual turtles, determine a population's (or species') mean age-at-maturity, and define age-based demography?

Understanding the demography of sea turtle populations is fundamental for accurate population models and conservation (see Q8). Age structure of individuals and populations, as well as age-at-maturity are crucial for such models, yet are among the most elusive aspects of sea turtle biology. So far, aging sea turtles has largely relied on skeletochronology, a technique that analyses humerus bones of dead animals (Zug et al. 1997, Snover \& Hohn 2004). Indeed, skeletochronology can determine individual age (IA), offer some inferences about population age distribution, and when combined with capture-mark-recapture (CMR) techniques, provide insights about age-atmaturity (AM) (Van Houtan et al. 2014a). However, progress in these areas has been slow and these tools have been applied sparingly, due to the limitation that dead carcasses are required.

During the past decade, there have been several advances in understanding IA and AM of sea turtles based on (1) study of captive turtle growth and maturation (Bjorndal et al. 2014), (2) application of the 'living tag' technique on hatchlings (Tucek et al. 2014), and (3) increased use of skeletochronology and growth analysis (e.g. Avens et al. 2009, 2015, Hawkes et al. 
2014, Ramirez et al. 2015, Turner-Tomaszewicz et al. 2015). New non-destructive, epigenetic approaches have also emerged for studying IA; however, these have yielded mixed results. For example, reduced telomere length in sea turtle blood cells has been suggested to be a function of age. However, while telomere length analysis has been promising in some cases (Hatase et al. 2008), others have found no link with age (Girondot \& Garcia 1999, Plot et al. 2012). Measuring DNA methylation within tissues is another epigenetic approach; this shows promise for the study of tissue-specific changes that occur as a result of aging (Richardson 2003, Varriale \& Bernardi 2006). Reduced DNA methylation in crocodilians has been shown to be a function of age (Nilsen et al. 2016), but substantial research and development is necessary to establish the efficacy of this technique for sea turtles.

Genetic approaches to determining AM represent a new frontier. Until now, CMR studies have been constrained by the absence of a reliable way of tagging hatchlings and identifying them later in life. Two recent advances have occurred that now make largescale and long-term CMR studies of hatchlings through adulthood feasible, using DNA as genetic 'tags'. Firstly, the development of rapid non-injurious methods for collecting small genetic samples from hatchlings in the field (Dutton \& Stewart 2013), and secondly, advancement in laboratory technologies for high throughput processing and genotyping of DNA (Hancock-Hanser et al. 2013). The rapidly accelerating pace of progress in molecular biology will continue to offer new techniques over the next decade to rapidly and cheaply genotype these DNA samples (Giardina et al. 2011, Schneider \& Dekker 2012).

Knowledge of sea turtle demography will continue to be paramount to aiding in population modelling and conservation planning. Whereas traditional approaches will continue to yield important insights in this realm, the advent of genetic and epigenetic approaches shows even greater promise for studying sea turtle age dynamics. As these technologies become widespread and cost-effective, there will be opportunity to develop long-term monitoring experiments with wild populations to validate age estimates (e.g. Dutton et al. 2005) and ultimately better understand population vital rates and heterogeneity among individuals.

Q8. What are the most reliable methods for estimating demographic parameters?

Important demographic parameters include abundance, fecundity, age at sexual maturity (see Q7), survival rates, and sex ratios (see Q2). Chaloupka \& Musick (1997), Heppell et al. (2003) and National Research Council (2010) presented in-depth summaries of sea turtle demography and the role that demographic parameters play in sea turtle population assessments. A wide variety of methods with long time-series of data are necessary to estimate these parameters for sea turtle populations.

On nesting beaches, total counting (census) of nests is generally unnecessary and often infeasible; sampling can be a cost-effective option for abundance estimates based on nest counts; there are different ways to sample nests on a beach and to statistically estimate the total number of nests from a sample (Jackson et al. 2008, Sims et al. 2008, Girondot 2010, Whiting et al. 2013, 2014a). A time-series of hatchling production is essential for determining the change in the productivity of a population (e.g. Brost et al. 2015). In recent years, genetics, satellite telemetry and ultrasonography have been used to generate improved estimates of clutch frequency, the number of nesting females, and effective population size (Tucker 2010, Blanco et al. 2012, Frey et al. 2014).

Somatic growth is determined through long-term capture-recapture studies (e.g. Hawkes et al. 2014, Colman et al. 2015). A combination of skeletochronological and stable isotope analyses can be used to estimate growth rates and age at maturity (e.g. Avens et al. 2013, 2015; see Q7). Data collection at foraging grounds is essential because multiple stage classes, both sexes and turtles originating from different rookeries can be sampled at the same time. To estimate demographic parameters at a foraging ground, distance sampling and CMR methods can be used. Distance sampling is useful for estimating density and abundance as a snapshot (e.g. Lauriano et al. 2011, Seminoff et al. 2014), whereas CMR methods are useful for estimating various demographic parameters with long-time series of data (e.g. Sasso et al. 2007, Patrício et al. 2014, Stewart et al. 2014). Although a CMR study using both nesting beaches and foraging grounds is needed to obtain rookery-specific estimates on survival and movement rates within a population, this kind of approach has not been implemented because of the logistical difficulty in collecting sufficient data at nesting beaches and foraging grounds simultaneously.

The sex ratio is a poorly understood demographic characteristic of sea turtle populations (see Q2). Primary sex ratios at a nesting beach have been estimated from histological examination of hatchlings, laparoscopy (after allowing some growth of the 
hatchlings), incubation durations, or environmental temperatures (e.g. Maulany et al. 2012, Woolgar et al. 2013, Lolavar \& Wyneken 2015, Marcovaldi et al. 2016; see Q2 for a discussion on methodological issues and new developments concerning primary sex ratio estimation). In foraging areas, hormonebased sex determination methods (Wibbels 2003, Braun-McNeill et al. 2007, Allen et al. 2015) require minimal invasive procedures and are promising; more validation studies of hormone-based methods should be conducted (e.g. Allen et al. 2015).

A fundamental issue in studies of sea turtle demography is the characterisation of the functional demographic units (Chaloupka \& Musick 1997), which can be accomplished via multiple techniques, including genetics, tagging and telemetry (Wallace et al. 2010; see Q4 and Q5). There exists a need for assessing the intrinsic variability of demographic parameters (Bjorndal et al. 2014, Tucek et al. 2014) and for comparing and combining subpopulation data to capture variabilities of demographic parameters in the wider population (Patrício et al. 2014, Bjorndal et al. 2016).

Q9. How can we develop an understanding of sea turtle metapopulation dynamics and conservation biogeography?

The first step is to identify the metapopulations. Significant advancements have been made in recent years, with the identification of groups of populations occupying large areas at the ocean basin level, such as RMUs by IUCN (Wallace et al. 2010) or Distinct Population Segments by NOAA, USA (e.g. Seminoff et al. 2015). These units were identified mainlyalthough not exclusively — through a high degree of genetic differentiation among nesting sites caused by the homing behaviour of adults, particularly of females. Hence, these units are basically 'anchored' to groups of nesting sites and may still be subject to changes. The same genetic data indicate that these large units are also structured internally (e.g. Carreras et al. 2014b, Shamblin et al. 2014, Bourjea et al. 2015a, Gaos et al. 2016, Vargas et al. 2016) and can be regarded as the metapopulations targeted by the present question. These unit approaches were particularly valuable and needed for circumglobal species, as many are known to exhibit local adaptations (Seminoff \& Shanker 2008, Wallace et al. 2011, Fukuoka et al. 2015, Liles et al. 2015, Vargas et al. 2016). For example, in the Indian Ocean and southeast Asia there are 9 RMUs identified by Wallace et al. (2010) but these 9 RMUs contain at least 30 genetically dis- tinct genetic stocks (Dethmers et al. 2006, FitzSimmons \& Limpus 2014).

A second step is to assess the structure within a metapopulation, with each population anchored to a nesting area (group of nesting sites with genetic similarity) and occurring at one or multiple foraging grounds. When compared to genetic data, the degree of geographic overlap among different populations can help in understanding metapopulation structure and dynamics. While a population is intrinsically linked to a nesting site, identifying foraging grounds is particularly challenging. First approaches to assess connectivity between nesting and foraging sites were represented by flipper tag returns (Mortimer \& Carr 1987, Limpus et al. 1992), satellite tracking of adults from nesting sites (reviewed in Godley et al. 2008, Hart \& Hyrenbach 2009, Jeffers \& Godley 2016) and genetic analyses of individuals sampled at foraging grounds (See Q4). However, these approaches are limited by numbers of tracked individuals and numbers of sampled foraging areas, respectively. Significant advancements are derived from coupling satellite tracking and stable isotope analyses (Zbinden et al. 2011, Ceriani et al. 2012, Pajuelo et al. 2012, Jones \& Seminoff 2013, Vander Zanden et al. 2015; see Q4 and Q6) and from understanding the role of currents in the dispersal of hatchlings into their future foraging grounds (e.g. Casale \& Mariani 2014, Putman \& Mansfield 2015, Naro-Maciel et al. 2016). Technological advances to track smaller turtles are improving the understanding of habitat use by sea turtles during their first and most cryptic life stage (Mansfield et al. 2014, Scott et al. 2014a; see Q5). All these aspects can also inform the degree of dispersal and exchanges within a metapopulation, which plays a key role in a context of extinction-recolonisation and, ultimately, in the vulnerability of the metapopulation. Understanding how specific features of different nesting sites affect metapopulation dynamics in terms of extinction-recolonisation cycles can inform where to prioritise conservation efforts. In this respect, attempts to consider factors like incubation temperature (Pike 2013a) and dispersal facilitation (Putman et al. 2010b) are promising.

A third step is to assess population-specific demographic parameters (see Q7 and Q8). While separate approaches at nesting sites and foraging grounds (e.g. for growth rate, fecundity) are consolidated, novel approaches can relate the 2 different habitats, for instance reproductive output as dependent on the foraging area (Zbinden et al. 2011, Vander Zanden et al. 2014, Ceriani et al. 2015, Patel et al. 2015b). 
In conclusion, despite significant advances in tools to determine population-level connectivity as well as the level of heterogeneity and the geographical range of a sea turtle metapopulation, a true understanding of metapopulation dynamics and the application of spatially structured models (Akçakaya 2000) are probably still far in the future.

Q10. What are the past and present roles of sea turtles in the ecosystem?

When recovery goals are set at returning sea turtle populations to 'fulfil ecological roles' (Bjorndal \& Bolten 2003), this definition extends beyond simple metrics of abundance or dietary intake, and precisely because of the complex nature of studying sea turtles in this context, research in this category remains underrepresented. Ecological models aimed at characterising the complexity of the relationships between organisms in a given ecosystem can allow an exploration of the consequences of different management scenarios, past and future impacts of fisheries and environmental disturbance, disease, or the carrying capacity for different species.

Ecopath trophic models that include sea turtles represent advances in understanding their ecological roles (Wabnitz et al. 2010, Viet Anh et al. 2014, Piroddi et al. 2015), but remain limited by the extensive data required for model parameterisation, as the analysis is highly dependent on the availability and quality of such data. Nevertheless, these models can provide insight into the structure and functioning of marine ecosystems. Additionally, other intrinsic markers such as stable isotopes and fatty acids can be important to understanding food web structure and the basal resources contributing to different food webs that include sea turtles (Cardona et al. 2015).

Some of the most pressing research needs identified in 2010 included studies to address roles of sea turtles as ecosystem engineers, nutrient transporters, consumers, and prey (Hamann et al. 2010). With respect to ecosystem engineers and consumers, research on green turtles - the only herbivorous sea turtle species - has composed the majority of research in these areas. The past and present roles of green turtle grazing in seagrass pastures and the regulation of green turtle populations by top-down vs. bottom-up processes are critical to understanding the ecosystem effects of green turtle recovery (Bjorndal \& Jackson 2003, Burkholder et al. 2013, Heithaus et al. 2014). As densities of green turtles increase in seagrass pastures, reports of 'destructive foraging' that may prevent seagrass recovery after grazing have garnered much attention (Fourqurean et al. 2010, Lal et al. 2010, Christianen et al. 2014). Understanding green turtle foraging strategies, including rotational grazing and cues that trigger patch abandonment (Bresette et al. 2010, Lacey et al. 2014, Molina Hernández \& van Tussenbroek 2014), as well as seagrass responses to grazing, are critical to evaluation of carrying capacities of seagrass pastures for green turtles. Whether high densities of green turtles represent historical conditions (Bjorndal \& Jackson 2003) or a release from predation with the decline of shark populations (Heithaus et al. 2014) is an essential question to ask when determining recovery goals in restoring ecosystem structure and function. Additionally, sea turtle grazing may have implications for the resilience of coral reef habitats, as hawksbills and green turtles target the consumption of algal turfs and macroalgae (Goatley et al. 2012).

Sea turtles have important roles in the terrestrial environment as nutrient transporters and prey. Nutrients from productive marine ecosystems are transported to less productive beach ecosystems by nesting turtles. These nutrient subsidies are assimilated by beach vegetation, predators, and detritivores and may influence the productivity and community structure of coastal ecosystems (Bouchard \& Bjorndal 2000, Hannan et al. 2007, Madden et al. 2008, Vander Zanden et al. 2012, Peterson et al. 2013). As prey, nesting sea turtles provide a supplemental food resource for terrestrial species such as jaguars, crocodiles, and alligators (Nifong et al. 2011, Whiting \& Whiting 2011, Veríssimo et al. 2012, Guilder et al. 2015), and as a possible last-resort resource for Mediterranean monk seals during the nesting season (Margaritoulis \& Touliatou 2011, Tonay et al. 2016). Sharks remain an important predator of sea turtles, and tiger sharks appear to alter their surfacing behaviour to enhance predation opportunities in areas of high sea turtle activity (Hammerschlag et al. 2015). Future emphasis should be on quantitative studies of all sea turtle species in oceanic, neritic, and terrestrial habitats that address the complex functions of sea turtles in healthy, functioning ecosystems.

\section{Q11. What constitutes a healthy turtle?}

This overarching question is addressed as 5 subtopics, as it was previously divided.

(1) The need for normal baseline physiological (blood work) studies. This has been amply addressed with numerous studies presenting basic haematology and 
blood chemistry: juvenile and adult loggerhead turtles (Delgado et al. 2011, Ley-Quiñónez et al. 2011, Flower et al. 2015, Kelly et al. 2015), juvenile and adult green turtles (Prieto-Torres et al. 2013, Lewbart et al. 2014, McFadden et al. 2014, Zwarg et al. 2014, Flint et al. 2015a, Li et al. 2015, Page-Karjian et al. 2015c), adult leatherback turtles (Harris et al. 2011, Perrault et al. 2012, Stewart et al. 2012, Innis et al. 2014), and hawksbill turtles (Montilla et al. 2014, Whiting et al. 2014b). Data for other species are still lacking and obtaining regional values for different subpopulations would contribute to better understanding spatial variation. Overall, these studies have enriched the archive of reference values that are needed to assess the health status of both free-ranging and rehabilitating turtles. Rehabilitation plays an important role in stabilising debilitated turtles (Baker et al. 2015) and reintroducing them into the wild, yet, a consensus on declaring a rehabilitated turtle suitably healthy for release has still to be achieved.

(2) Impacts of disease on population viability. This hinges on ways to assess or predict the survivorship of sea turtles carrying disease and prevalence of the disease within the population. Flint et al. (2015b) identified clear links between infectious and non-infectious diseases and poor body condition of green turtles. Similarly, Work et al. (2015a) identified infectious/ inflammatory diseases as a significant contributor to turtle mortality (18\% of known causes of death) in green turtles. Page-Karjian et al. (2014) found that ocular tumours increased the likelihood of mortality eight fold in turtles with fibropapillomatosis (FP). Finally, a number of sea turtle health and mortality indexes (based on blood chemistry) recently proposed for predicting sea turtle survival (e.g. Stacy et al. 2013, Li et al. 2015) could have important applications.

(3) The role of environmental factors in disease. This remains poorly understood, but there are some recent advances in understanding the links between climate change and sea turtle health. Extreme temperatures can lead to sea grass diebacks, reducing body condition of green sea turtles (Thomson et al. 2015a). Climate change has also been linked to increases in the geographic distribution, intensity, frequency and toxicity of harmful algal blooms (Wells et al. 2015). Cold stress continues to be an issue in eastern USA, and an index to predict events has been developed (Pirhalla et al. 2015).

(4) Health impacts. Helminth parasites continue to dominate the infectious disease literature for sea turtles (Werneck \& Silva 2015), and a new coccidian parasite has been found in leatherback adrenals (Ferguson et al. 2016). Fungi are starting to become more prominent, with recent descriptions of new fungal infections in green (Donnelly et al. 2015) and loggerhead (Schumacher et al. 2014) turtles, and documentation that the ovopathogenic fungus Fusarium has a broad global distribution (Sarmiento-Ramírez et al. 2014a). There is also increasing evidence that exposure of sea turtles to marine toxins can be widespread (Capper et al. 2013) and adversely affect turtle health (Fauquier et al. 2013) (see Q15).

(5) Health status of pelagic turtles. This remains poorly understood, primarily due to the lack of information on this life stage (see Q5).

Overall, there is a clear need for new and innovative laboratory tools to understand physiology and disease pathogenesis. Several new such tools have recently been developed: computer-aided tomography to diagnose decompression sickness (GarcíaPárraga et al. 2014); COMET assay to look at DNA damage (Caliani et al. 2014); haemoglobin binding protein adds to the repertoire of acute phase proteins useful for monitoring turtle health (Dickey et al. 2014); and laser capture microdissection (Page-Karjian et al. 2012).

Q12. What will be the impacts from climate change on sea turtles and how can these be mitigated?

Given the potential impacts of climate change on sea turtles, there has been a substantial growth in the number of studies exploring this topic. Most of the earlier studies explored the relationship between temperature and the sex of sea turtles (Mrosovsky et al. 1984) and highlighted potential impacts from projected increases in temperature. Consequently, several studies have estimated primary sex ratio at nesting grounds (Fuller et al. 2013, Marcovaldi et al. 2016) and predicted sex ratios under several scenarios of climate change (Hawkes et al. 2007, Laloë et al. 2014), using a variety of proxies (Girondot \& Kaska 2014, 2015, Wyneken \& Lolavar 2015; see Q2).

Despite a more robust understanding of sex ratio baseline in advance of climate change, limited knowledge still exists in relation to the operational sex ratio of the sea turtle population, and this has been highlighted as an emerging theme, although some studies have made some advancements in this area (see Hays et al. 2010b, 2014a, Wright et al. 2012, Lasala et al. 2013, Laloë et al. 2014). A focus also exists on the implications of projected increases in temperature on hatching success and population sustainability (Santidrián Tomillo et al. 2014, 2015a,b; see Q3), with recent work suggesting that the embryos of some 
species may be more resilient to higher temperatures than previously thought and that their thermal tolerance may change as they grow (Howard et al. 2014, 2015).

The development of new biomarkers to detect thermal stress on clutches is a promising tool to detect the negative effects on the nesting environment and the resilience of embryos to extreme heating events (Tedeschi et al. 2015). The direct effect of temperature on hatchling attributes has also been explored, including clutch success, hatch weight and hatchling performance (Dudley \& Porter 2014, Fisher et al. 2014, Horne et al. 2014). Further, studies have focused on impacts of sea level rise on nesting grounds and future availability of nesting areas (Katselidis et al. 2014, Patino-Martinez et al. 2014, Calvillo Garcia et al. 2015) as well as the overlap between cyclonic activities and nesting activities (Fuentes et al. 2011a, Dewald \& Pike 2014, Kumar et al. 2014) highlighting the fact that monitoring the morphological changes of nesting habitat is a key factor in assessing the impact of climate change on sea turtles (Yamamoto et al. 2015).

Advancements have been made in evaluating the impacts of climate change on the oceanic realm; predicted variations in wave regimes and currents (Osorio et al. 2014) may have a great impact on foraging areas for several sea turtle species (Robinson et al. 2014, Thomson et al. 2015a, Willis-Norton et al. 2015), highlighting the need to also monitor the vulnerability of the ecosystems used by sea turtles. Typically the impacts of climatic processes on sea turtles have been explored individually, but processes are likely to occur simultaneously with other anthropogenic threats and cause cumulative and synergetic effects, emphasizing the need to simultaneously analyse multiple threats (Fuentes et al. 2011b). This is important, since the resilience of sea turtles to climate change is likely affected by several factors including non-climate-related threats such as disease, pollution and fisheries interactions (Fuentes et al. 2013, Abella Perez et al. 2016). The adaptive capacity of sea turtles to climate change, among other factors, may be dependent on their dispersal potential (Boyle et al. 2014). This dependence is especially relevant as climate change has been suggested to affect dispersal by impacting key offspring attributes, such as fitness (Cavallo et al. 2015, Sim et al. 2015). Some changes in the timing of the nesting season, possibly as an adaptation, have been detected and related to sea surface temperature (Neeman et al. 2015b). Adaptive capacity will also be dependent on the future availability of habitat with optimal incubating environ- ment (Pike 2013b). Thus, further knowledge of the factors contributing to population expansion and species range, such as nest site selection, fidelity and dispersal from nesting areas is important (Pike 2014, Mazaris et al. 2015, Neeman et al. 2015c, Pikesley et al. 2015, Maffucci et al. 2016). Although several strategies (e.g. shading of nests, sprinkling, assisted migration) have been suggested to mitigate potential impacts from climate change on sea turtles (Wood et al. 2014, Hill et al. 2015b, Jourdan \& Fuentes 2015, Lopez et al. 2015), there is general consensus that robust knowledge of their risks and effectiveness is needed before implementation.

Q13. What are the major sources of fisheries bycatch and how can these be mitigated in ways that are ecologically, economically and socially practicable?

Drifting longlines have attracted most of the research attention during the past 5 years, partially because along with purse seiners, industrial longliners often carry on-board observers collecting bycatch data. As a result of this new information, researchers have developed risk assessment models (Fossette et al. 2014, Roe et al. 2014, Pikesley et al. 2015) and tools to help predict bycatch risk in near-real time (Howell et al. 2015). There is also growing evidence that hook removal has the potential to reduce postrelease mortality (Swimmer et al. 2006, Álvarez de Quevedo et al. 2013, Swimmer et al. 2014, Gilman \& Huang 2016).

Recent research on trawl fisheries has demonstrated that in some regions, only bottom trawls operating on shallow water are likely to catch significant numbers of turtles (Warden 2011, Domènech et al. 2015). Although turtle excluder devices (TEDs) and tow times have been enforced in some fleets operating in shallow water, recent evidence indicates that captured turtles may suffer decompression sickness, and hence there is a high risk of significant post-release mortality (García-Párraga et al. 2014). There remains an urgent need to assess post-release mortality of turtles caught in bottom trawls.

There is increasing evidence that passive net fisheries, drift nets in particular, are a major threat for sea turtles in many ocean regions around the world (e.g. Gilman et al. 2010, Casale 2011, Wang et al. 2013a, Wilcox et al. 2013, Girard et al. 2014, Ayissi et al. 2015, Ortiz et al. 2016). Many of these are smallscale fisheries that are poorly monitored and studied. The use of LED lights or chemical light sticks has proven promising in reducing bycatch (Wang et al. 
2010, 2013a, Ortiz et al. 2016), as well as the use of buoyless nets (Peckham et al. 2016). However, the use of shark models, as visual deterrents near fishing gear may also reduce the value of the commercial catch to unacceptable levels (Wang et al. 2010, Bostwick et al. 2014). These mitigation measures require additional testing in other fisheries before their use can be recommended.

Recent studies indicate very low levels of bycatch associated with purse seiners (Hall \& Roman 2013, Bourjea et al. 2014). Drifting fish aggregating devices (DFADs), however, might result in some ghost fishing (Balderson \& Martin 2015, Maufroy et al. 2015). It is therefore essential to assess the magnitude of overall mortality of turtles through entangling in DFADs at sea or beached.

Efforts to develop risk assessment models, predict the demographic consequences of bycatch and set limit reference points (Curtis et al. 2015a,b, Murray 2015, Warden et al. 2015, Casale \& Heppell 2016) are complicated by: variation over time in fishing gear and fishing area resulting in fluctuations in turtle bycatch (e.g. Álvarez de Quevedo et al. 2013, 2014, Báez et al. 2014a,b); poor coverage of species' entire foraging grounds affected or the suite of fisheries operating in a region (with small-scale fisheries particularly under-represented; Alfaro-Shigueto et al. 2010); and large uncertainties about reproductive parameters (Warden et al. 2015) and post-release mortality (Murray 2015).

Further research should encompass all major fisheries of concern, assess both direct and post-release mortality, determine the species and natal populations of captured turtles (Dutton et al. 2014b), contextualize bycatch figures according to life stage and population size, and periodically update bycatch numbers (Casale \& Heppell 2016). Additional effort is required in regions other than the North Pacific, North Atlantic and Mediterranean, because large portions of the oceans and their resident turtle populations are under-studied and vulnerable to massive levels of fishing effort, especially from net gears. Artisanal fisheries deserve particular attention and on-board observers may play a critical role in the monitoring of industrial fleets.

Q14. How can we evaluate the effects of anthropogenic factors on sea turtle habitats?

Recent advancements in remotely sensed data and spatial analysis tools have greatly improved our ability to map sea turtle habitats, detect changes over time and model habitat suitability. For example, Hedley et al. (2016) mapped persistence of seagrass habitat in Moreton Bay from 1998 to 2010, Yamamoto et al. (2015) mapped morphological changes of nesting beaches in southeastern Florida from 1999 to 2005, and Dunkin et al. (2016) mapped loggerhead nesting habitat suitability along part of Florida's Atlantic coast. In addition, cumulative human impacts in marine environments (e.g. climate change, pollution, commercial shipping) have been mapped on a global scale (Halpern et al. 2015). These types of studies generally have a global overview and focus on a particular habitat type (e.g. seagrass, mangroves, coral reefs). However, it could be argued that understanding the anthropogenic effects on marine habitats at a coarse, global scale is, in fact, providing important information on the human impacts in local sea turtle habitats. Certainly, there is great potential within the current literature to overlap global anthropogenic-induced changes to marine habitats with known sea turtle habitat locations. However, there is still some question as to whether the scale of these global assessments is fine enough to provide meaningful information about the anthropogenic impacts within specific sea turtle habitats.

The effects of sea turtle habitat degradation on sea turtle populations have been relatively well researched in recent years (Mathenge et al. 2012, Schuyler et al. 2014a, Vander Zanden et al. 2016), as have acute, large-scale impacts such as the BP Deepwater Horizon discharge (Bjorndal et al. 2011, Putman et al. 2015a, Vander Zanden et al. 2016). Research has continued to assess the impact of nesting beach development on nesting turtles (Flores-Monter et al. 2015), and the effects of artificial lighting on hatchling dispersal and nesting (Kamrowski et al. 2012, 2014a, Berry et al. 2013). Assessments of specific anthropogenic impacts on sea turtles on nesting beaches continue (e.g. van de Merwe et al. 2012). In addition, it could be argued that impacts such as climate change (see Q12; although impacts may not always be negative, Hawkes et al. 2007) and pollution (see Q15) are affecting sea turtle populations via habitat degradation. For example, increases in nesting beach temperature affect hatchling survival and sex ratios (Santidrián Tomillo et al. 2015a), and accumulation of plastic in core foraging areas results in plastic ingestion in young green turtles (González Carman et al. 2014a). A threat of emerging concern is that of anthropogenic noise (Estabrook et al. 2016, Nelms et al. 2016a)

However, due to the often cumulative nature of human-induced impacts on sea turtle habitats, deci- 
sion and risk-based frameworks (e.g. Whittock et al. 2014, Fuentes et al. 2015b, Riskas et al. 2016) are required to better identify the most important impacts of anthropogenic activities on sea turtle populations. Likewise, more studies establishing attributes of good quality habitat (e.g. beach characteristics and environmental conditions that support mass nesting events, Barik et al. 2014; see Q1) are needed for a systematic evaluation of sea turtle habitats. This will promote more efficient and effective allocation of conservation and management resources.

Q15. What are the impacts of pollution on sea turtles and their habitats?

The primary pollutants influencing sea turtles and their ecosystems may be grouped into plastic and other debris (including microplastics), toxins, and nutrient runoff. Although not discussed here, artificial lighting and anthropogenic noise are discussed elsewhere (see Q14).

The understanding of the impacts of plastic debris, broadly to marine life (Vegter et al. 2014, Ryan 2016) and specifically to sea turtles, has gained significant attention since the previous review (Barreiros \& Raykov 2014, Schuyler et al. 2014a, 2016, de Carvalho et al. 2015, Nelms et al. 2016b). Acute threats posed by plastic debris include physical entanglements in derelict fishing gear (discarded monofilament lines, 'ghost' nets etc.) and other plastic debris (Poli et al. 2014, Wilcox et al. 2015). Mortality associated with gastrointestinal tract blockage from ingested plastic is another known acute impact. Ingestion of debris can also cause sub-lethal effects such as internal injuries, dietary dilution, malnutrition, and increased buoyancy (Nelms et al. 2016b). These effects may result in poor health, reduced growth rates and reproductive output but are not well quantified. Additional indirect impacts may include harm from persistent organic pollutants that adsorb to ingested plastic, and endocrine disruption resulting from chemicals leached from plastic (Santos et al. 2015), but these are also poorly understood and challenging to obtain (Casale et al. 2016).

Juveniles may be particularly susceptible to ingestion of plastics, as the offshore convergence zone ecosystems where they reside also concentrate ocean debris (González Carman et al. 2014a, Van Houtan et al. 2016). Further research to locate these areas (see Q5) and understand the trophic structure of these ecosystems (Choy et al. 2015) and the resulting bioaccumulation of contaminants is needed. There is increasing research on the detection of microplastics in the marine environment and marine fauna, both resulting from macroplastic degradation or from sewage. However, very little is published on the presence or impact of microplastics on sea turtles, and this deserves future attention.

Literature on the accumulation of heavy metals (e.g. García-Fernández et al. 2009, Bucchia et al. 2015) and organic contaminants (e.g. Orós et al. 2009, Lazar et al. 2011, Camacho et al. 2013b) in sea turtles continues to grow. However, only 3 studies have further assessed the risks associated with chemical accumulation in sea turtles (Lam et al. 2006, van de Merwe et al. 2009, Dyc et al. 2015). Toxicity of heavy metals varies with species, developmental stage, environmental conditions, and the anthropogenic source (Godley et al. 1999, references in Bucchia et al. 2015). Maternal transfer of pollutants to eggs has also recently been described (Guirlet et al. 2008, 2010, van de Merwe et al. 2010, Ikonomopoulou et al. 2011), indicating potential risk to developing embryos. However, very little is known about the toxic effects of chemical contaminants on sea turtles (Finlayson et al. 2016). Most recent studies in this area focus on correlations between contaminant concentrations (mostly PCBs, PAHs and DDT) and effects, such as clinical blood parameters (e.g. Swarthout et al. 2010, Komoroske et al. 2011, Camacho et al. 2013a,c), FP (e.g. Keller et al. 2014, da Silva et al. 2016; see Q16), diseases (e.g. Orós et al. 2013) and hatchling body condition (e.g. Perrault et al. 2011). Not surprisingly, considering the conservation status of sea turtles, direct in vivo exposure of contaminants to measure toxicity has decreased in recent years. More recently, in vitro, or cell-based, approaches have been used as an ethical alternative for assessing the effects of contaminants in sea turtles (e.g. Wang et al. 2013b, Webb et al. 2014, Wise et al. 2014, Young et al. 2015). Investigating toxicity thresholds for pollutants and the effects of complex chemical mixtures are important areas for future research.

Oil spills can lead to varied threats, including injuries, oil-derived toxic effects and habitat degradation (Putman et al. 2015a). However, immunotoxicity is not typically assessed during oil spills (Barron 2012). On the other hand, due to the migratory behaviour and sharing of feeding grounds, oil spills may impact turtles from different, distant populations (Putman et al. 2015a).

Exploratory analyses must also be carried out to reveal the presence of currently undetected pollutants from land-based activities. Land-based nutrients originating from human wastewater and agri- 
culture cause eutrophication, harmful algal blooms, hypoxia, and alter coastal ecosystems dramatically (Carpenter et al. 1998). Cyanobacteria blooms favoured by such wastes, e.g. Lyngbya majuscule blooms in East Australia, are noted to impact sea turtle habitats and turtle health, but to varying degrees over large spatial scales (Arthur et al. 2006, 2008). Impaired waterways are often hotspots for FP (Aguirre \& Lutz 2004), and eutrophication has recently been linked as a potential key factor (Van Houtan et al. 2010; see Q16).

Q16. What are the etiology and epidemiology of fibropapillomatosis (FP), and how can this disease be managed?

Since the previous update, there have been 2 published reviews (Kane et al. 2012, Jones et al. 2016) and one international symposium (Hargrove et al. 2016) on FP, all identifying needs for research that may lead to better understanding of the manifestation, occurrence, cause, and population impacts of FP. Though yet to be conclusively proven, FP is still considered to be caused by a herpesvirus. Description of the genetic sequence of the ChHV5 virus (Ackermann et al. 2012) was a big step forward. Further, a global phylogeography of FP-associated herpesviruses (Patrıcio et al. 2012) revealed no recent viral mutations, suggesting the recent epizootic may be driven by other factors. Nested and quantitative PCR documented high levels of ChHV5 in normal tissues of several species (Page-Karjian et al. 2012, Alfaro-Núñez \& Gilbert 2014, Alfaro-Núñez et al. 2014, 2016, Page-Karjian et al. 2015b).

Aside from the well-known occurrence of FP in green turtles from Hawaii, Florida, and Australia, more information is emerging in other regions. New descriptions of FP for olive ridleys in Costa Rica (Chaves et al. 2013), green turtles in Principe (Duarte et al. 2012) and Brazil (Rodenbusch et al. 2012, Rodenbusch et al. 2014, Zwarg et al. 2014, Monezi et al. 2016), and loggerheads in Brazil (Rossi et al. 2015) are available. In green turtles, the population-level prevalence varies among sites (e.g. Sterling et al. 2013, López-Mendilaharsu et al. 2016). Turtle fishers in the Caribbean may elevate FP prevalence by selecting against tumoured turtles (Stringell et al. 2015b).

Previously documented in Hawaii, tumour regression was also described in Brazil (Machado Guimarães et al. 2013) and Puerto Rico (Patrício et al. 2016). For Puerto Rico green turtles, FP does not appear to be influenced by demographics (Patrício et al. 2011, 2016) and may not always alter growth rates (Patrício et al. 2014). In Hawaii, disease transmission may depend in part on disproportional viral shedding from a few individuals (Work et al. 2015c). Electrotherapy (Brunner et al. 2014) and phototherapy (Sellera et al. 2014) may be promising tools for treatment of affected turtles. Additional studies retrospectively examined FP rehabilitation cases in green (PageKarjian et al. 2014) and loggerhead (Page-Karjian et al. 2015a) turtles from Florida.

FP has long been associated with impaired coastal ecosystems but the exact mechanisms are unknown (see Q15). Heavy metal burdens are associated with FP in green turtles from Brazil (da Silva et al. 2016). However, persistent organic pollutants do not appear to be associated with FP in green turtles from Hawaii (Keller et al. 2014) or Brazil (Sánchez-Sarmiento et al. 2016). In Hawaii, FP is prevalent in watersheds where invasive algae and land-based nutrients are chronic management concerns (Van Houtan et al. 2010). Elevated nitrogen is sequestered by macroalgae in arginine, which when consumed, may contribute to FP by promoting herpes (Van Houtan et al. 2014b), but this is subject to debate (T. M. Work et al. unpubl. data).

Q17. How can we effectively determine the conservation status of sea turtle populations?

This can be divided into 2 sub-questions: (1) What is the appropriate conservation unit and (2) What are the appropriate methodological approaches to assess the extinction risk and type of data required?

(1) The IUCN Red List assessments are the most cited. Significant advancement has been made from the original global scale at species level to a new scale: the RMU (Wallace et al. 2010). Thus far, the RMU approach has been applied to leatherback and loggerhead sea turtles (www.iucnredlist.org), while others are underway. Although an improvement, an RMU may include several biological units whose individual fate is not reflected by the overall risk assessment. As genetic markers improve, smaller biological units are recognised (Shamblin et al. 2015a,b, Gaos et al. 2016).

(2) Trends or indices of abundance are often used to determine population status, but require precise annual abundance estimates, which can be difficult to ascertain (see Q8). Thus, models have been developed to obtain reliable abundance estimates from partial nest counts (e.g. Girondot 2010, Delcroix et al. 2014, Whiting et al. 2014a). Trend analysis can be 
improved by additional demographic parameters obtained through physical tagging (flipper and PIT) of nesting females (e.g. survival, movements, detection, recruitment of nesting females; Pfaller et al. 2013, Stokes et al. 2014, García-Cruz et al. 2015). However, these analyses require consistent, thorough data collection, which may be implausible at remote nesting beaches. To include more than adult females in trend analysis, in-water indices (e.g. Bresette et al. 2010, Pons et al. 2010, Casale et al. 2012, Redfoot \& Ehrhart 2013, Lagueux et al. 2014, Patrício et al. 2014, 2016, Williams et al. 2015), especially for the juvenile life-stages, are necessary to complement nesting indices and detect population changes before they are observed at nesting beaches (see Q7 and Q8). Unfortunately, abundance estimates at foraging areas are challenging to obtain and unavailable for many populations (Fuentes et al. 2015a). Possible future technological development may include the use of drones or improvements to sampling techniques such as photo identification coupled with citizen science. These would reduce or eliminate the cost and risk of conducting aerial surveys at nearshore foraging grounds and nesting beaches. With these demographic data, the status of a marine turtle population can be determined via population modelling, which can be used to estimate the probability of persistence (e.g. Dethmers \& Baxter 2011).

Additionally, incorporating the human dimensions, via traditional ecological knowledge, can strengthen species assessments and provide unique insight into a population's conservation status, especially for datalimited populations and locations where baselines are lacking (Sáenz-Arroyo et al. 2005, Drew \& Henne 2006, Fraser et al. 2006, Gaos \& Yañez 2012). To include human dimensions, combining the social (e.g. interviews, workshops) and natural sciences can provide unique insight via traditional ecological knowledge. Studies have used this inter-disciplinary approach to assess local perceptions of species (Gaos et al. 2010, Butler et al. 2012, Braga \& Schiavetti 2013, Liles et al. 2014), sea turtle bycatch in artisanal fisheries (Moore et al. 2010, Braga \& Schiavetti 2013), and to inform species assessments of endangered whales (Frans \& Augé 2016).

Q18. What are the most viable cultural, legal and socioeconomic frameworks for sea turtle conservation?

Generally, the same 4 categories identified by Hamann et al. (2010) addressed topics related to cultural, legal, and socioeconomic frameworks of con- servation. From the literature reviewed, we found the emphasis remained on description and assessment, rather than quantifying relative costs and benefits and how they are distributed among impacted human populations. Slow progress has been made, although there have been some novel approaches. These include several methods for ecological assessments and further identification of conservation priorities - such as the use of fuzzy logic mathematical systems (Aguilar-González et al. 2014), habitat modelling (Fujioka et al. 2014a), modelling food webs (Viet Anh et al. 2014), modelling of threat risk and mitigation measures (Kvamsdal \& Stohs 2014, Watson \& Bigelow 2014), and including budget constraints together with local and expert opinions (Fuentes et al. 2015b) - in order to model cost effective management options (Gjertsen et al. 2014). A further novel approach was the use of religious education addressing turtle conservation (Macrae \& Whiting 2014).

Several studies have shown the importance of applying inter-disciplinary frameworks which consider social, cultural, ecological and governance factors to bring about management changes (Jackson et al. 2015, Stringell et al. 2015a, Teh et al. 2015). However, the limitations on the extent to which research can effectively support legislation, management and overall conservation seem to be a general concern (Lagueux et al. 2014, Kvamsdal \& Stohs 2014, Harris et al. 2015, Humber et al. 2015, Lewison et al. 2015, Lopez 2015, Lopez et al. 2015, Stringell et al. 2015a). For instance, sea turtle conservation within the context of other long-distance marine migratory species (Gredzens et al. 2014, Lascelles et al. 2014), assessments of critical habitat and environmental sensitivity (Lopez et al. 2015, Martin et al. 2015b), management of wider ocean ecosystems (Maxwell et al. $2014,2015)$ and understanding the connections between diverse stakeholders (e.g. Weiss et al. 2012, 2013) all call into play broad international and crosssector governance and legal issues which are as yet unresolved. Insufficient integration and application of social and natural science in institutions, agencies, universities, and organisations remains an impediment, along with the limits to collaboration created by thematic siloes.

Although on the increase, psychological and behavioural research is still limited (Kamrowski et al. 2014b, McDonald et al. 2014, Hill et al. 2015a). Neuropsychology, neuroeconomics and neuroconservation are areas to watch for emerging themes and breakthrough insights within this category, as applications of neuroimaging technology become more viable. Studies of the cognitive, emotional, psycho- 
logical, social, and spiritual value of access to 'blue space', wildlife, and biodiversity will begin to include sea turtles, their habitat, and conservation projects (Kuo 2015, Cracknell et al. 2016, White et al. 2016).

Despite some historical knowledge of sea turtle fisheries around the world (Halkyard 2014, Lagueux et al. 2014, Van Houtan \& Kittinger 2014), we still have a lot to learn about the long-term impact of harvests. On the other hand, with successful conservation efforts, some sea turtle populations have been downlisted. In many places the conversation about legal consumption (see Q20) is increasing and will have to be addressed within cultural, legal, and socioeconomic frameworks to avoid conflict. Thus, studies of conflict resolution will be useful in addressing these issues.

As technologies to monitor both human and animal behaviour expand in use, concerns about privacy, rights, and access to data will enter this discussion with increased frequency, and could be considered an emergent area for further study. Conservation efforts must adapt to this digital age through a better appreciation of the drivers of human behaviour, social structure and effective communication. Advancements on these emerging themes may help resolve some of the longstanding challenges, limitations, and conflicts by offering a wider, deeper, and more inclusive and robust framework for understanding the human-sea turtle relationship.

\section{Q19. Which conservation strategies are working} (have worked) and which have failed?

Complex population dynamics and life cycles, long lifespans and extended generation times, and multiple natural and anthropogenic stressors across wide distributions present significant challenges to comprehensive, effective conservation approaches for sea turtles. There is clearly room to improve the critical appraisal of our interventions and to incorporate lessons learned from holistic approaches to sea turtle conservation that explicitly integrate human communities at relevant geographic scales to maximise their effectiveness. See discussion of evidence-based conservation (Flaspohler et al. 2000, Pullin \& Knight 2001, 2009, Pullin et al. 2004, Sutherland et al. 2004, Fazey et al. 2005) and scale-dependent engagement of human actors in holistic sea turtle conservation (Campbell 2007, Dutton \& Squires 2011). A comprehensive, integrated analysis of current conservation practices that includes political and human dimensions at different geographic scales (sensu Frazier
1999, Marcovaldi \& Thomé 1999, Campbell 2007, Dutton \& Squires 2011) is beyond the scope of this section; below we focus discussion on the progress (or lack thereof) of some sea turtle conservation approaches in recent years.

Decades of protection of females at nesting beaches and the advent of CITES and locally enabling legislation have likely contributed to successful population recovery at nesting sites around the world (Dutton et al. 2005, Marcovaldi \& Chaloupka 2007, AbreuGrobois \& Plotkin 2008, Chaloupka et al. 2008, Allen et al. 2010, Mortimer et al. 2011, Ehrhart et al. 2014, Weber et al. 2014, Balazs et al. 2015b, Bourjea et al. 2015b). Preserving nesting females (and their breeding, migratory and foraging habitats) remains an essential element of any conservation programme because their delayed sexual maturity and lifetime fecundity makes each mature female disproportionately valuable to the population. In contrast, conservation efforts focused only on the youngest sea turtle life stages have not shown clear benefits-e.g. $19^{\text {th }} / 20^{\text {th }}$ century fisheries legislation protecting small turtles preferentially to adults (Mortimer 1984), and head-starting of hatchlings in captivity (Mortimer 1995, but see Bell et al. 2005). Nevertheless, it is essential to develop conservation strategies that also target the often overlooked in-water life stages (Crouse et al. 1987). Efforts must be expanded to address threats to, and monitor status of, all life stages of individual population segments to effect durable sea turtle population recoveries. In some cases, this can be challenging: for example, green turtle recovery in various geographies is leading to concerns regarding ecosystem collapse and human-wildlife conflict (Lal et al. 2010, Christianen et al. 2014) in some instances, while in others it has been posited that increases in abundance may be a result of predator release due to shark overfishing (Heithaus et al. 2014).

A major threat is fisheries bycatch (see Q13), and there have been significant advances evaluating and addressing this threat, particularly in small-scale fisheries in developing nations (Wallace et al. 2013, Lewison et al. 2015). Rapid, port-based interviews and radio communication with fishers from large numbers of ports provide baseline information about sea turtle bycatch in fisheries that are typically poorly monitored, if at all, by conventional techniques (e.g. onboard observers) (Alfaro-Shigueto et al. 2011, 2012). The ability to identify areas of bycatch risk improves predictions and informs management through analyses that overlay sea turtle distribution and abundance, fishing effort, and environmental correlates of both (Howell et al. 2008, Fossette et al. 2014, Roe et al. 
2014). Although effectiveness of bycatch mitigationtypically through changes in fishing gear - has been the focus of more critical research effort than any other interventions (Gilman et al. 2006, 2007, 2010, Read 2007, Alessandro \& Antonello 2010, Bostwick et al. 2014, Senko et al. 2014b, Ortiz et al. 2016, Peckham et al. 2016), there is a paucity of published papers evaluating the success of other conservation interventions in reducing effects of bycatch on sea turtles, especially in recent years. Exceptions include efficacy of marine protected areas (Revuelta et al. 2015a) and rehabilitation success (Baker et al. 2015).

Restoring sea turtle populations to their historic abundance may be infeasible in most cases, given the current state of available habitats and anthropogenic threats. Nonetheless, tangible, measurable recovery goals are needed to orient management efforts, especially at regional and global scales. Indeed, several sea turtle populations have increased significantly in abundance, thrusting a challenging, but positive, question before the conservation community: What protections should remain in place, if any, when a population reaches levels by status assessment frameworks (e.g. IUCN Red List, USA Endangered Species Act, Australia's Environmental Protection and Biodiversity Conservation Act) that merit 'downlisting' to less- or non-threatened categories? There is a valid concern that downlisting will encourage excessive resource use by communities whose activities are currently constrained by protective regulations (see Q20). However, conservation approaches should engage human actors appropriately at different geographic scales, paying special attention to how communities use, value, and manage sea turtles at local scales (Campbell 2007). Nevertheless, as this challenge continues to emerge, the sea turtle conservation community must embrace a holistic perspective that recognises the need to both celebrate and ensure conservations gains.

Q20. Under what conditions (ecological, environmental, social and political) can consumptive use of sea turtles be sustained?

The issue of sustainable use of sea turtles continues to be contentious (Campbell 2012). Since 2010, 3 categories of research have featured in the literature: (1) biological sustainability, (2) social, economic, or cultural sustainability, or (3) both of the above. Although there are studies of illegal take of sea turtles and eggs, we focus on legalized take regimes where sustainability is an explicit or implicit goal.
In the first category, studies focus on documenting and describing levels of legal take of sea turtles, either for a specific project or area over time (Humber et al. 2011, Valverde et al. 2012, Lagueux et al. 2014), or globally (Humber et al. 2014). These datasets provide necessary information for improved understanding of what kind of directed take exists, and help establish a baseline against which to evaluate future trends. Beyond this, focused research on what level of harvest is sustainable to the target population is relatively rare. Nearly all recent research on harvest has focused on stage class survivorship and population trends of turtle rookeries exposed to directed take of either eggs or later life stages, and these studies tend to suggest that any harvest will cause population decline (e.g. Campbell \& Lagueux 2005, Santidrián Tomillo et al. 2008, Macrae \& Whiting 2014, Senko et al. 2014a, Bourjea et al. 2015b), even if there has been no documented decline in all the study populations.

In the second category, 2 relevant papers were published in the same year as the Hamann et al. 20 questions, in a special issue of the journal Conservation and Society dedicated to social science research on sea turtle conservation (Campbell 2010, Garland \& Carthy 2010). Garland \& Carthy (2010) describe shifts in consumption of turtle meat among the Miskito people of Nicaragua, and how this was influenced by changing taste preferences and economic context, among other things. They found pressures for both increased and decreased consumption in the future. Grayson et al. (2010) evaluate the potential for community-based versus regionally-based comanagement of sea turtles by Hammond Islanders in the Torres Straits, with the aim of balancing the rights of Torres Strait Islanders with long-term sustainability of turtle harvesting. More recently, a long standing and well known case of use - the legal harvest and sale of olive ridley sea turtle eggs from Ostional, Costa Rica (Campbell 1998, Campbell et al. 2007) - was assessed through the lens of common property resource (CPR) theory. Madrigal-Ballestero et al. (2013) analyse how rule-following behaviour among egg harvesters varies according to demographics, economic dependence, perceived legitimacy of rules, and social norms. Schlüter \& Madrigal (2012) also use the Ostional case to further methodological thinking about social-ecological systems. All these studies recognise that questions of biological sustainability do not exist in isolation; they are tightly linked to, and arguably dependent on, social, economic, and cultural sustainability of institutions guiding management. 
The third category both recognises, and empirically interrogates, these linkages. A multi-disciplinary study on the legal fishery of green and hawksbill turtles in the Turks and Caicos Islands (Richardson et al. 2009) assessed ecological, social, economic, and cultural aspects of the fishery, and led to national legislative changes. These changes were directed at maintaining the fishery while reducing negative impacts to population growth and on the more vulnerable hawksbill turtle (Stringell et al. 2015a). An innovative participatory research method (CommunityVoice Method.org) was used both to collect data and to engage fishers and community members in discussing and vetting the recommended legislative changes before they were submitted to government (see TCI case study in Christie et al. 2014). Continued monitoring will reveal whether this fishery is sustainable, and highlights the need for long-term monitoring for assessing sustainability.

Although legal harvest regimes for sea turtles are uncommon in contrast to other conservation approaches, the need to assess the possibilities for sustainable use remains. For example, green turtles make up more than $80 \%$ of turtles harvested legally world-wide (Humber et al. 2014), and with the recovery of many green turtle rookeries globally (Weber et al. 2014, García-Cruz et al. 2015), we need further research into how to manage turtle fisheries to minimize negative impacts, as it is unlikely that they will become a thing of the past. Research must include socio-economic studies into the drivers of both legal and illegal fisheries in order to better manage and protect populations (Hancock et al. in press).

\section{GENERAL DISCUSSION}

This review finds that significant effort is being expended towards global research priorities for management and conservation of sea turtles. Sea turtles are now a very well researched taxon, and are subject to a wide variety of conservation actions which appear, in some cases, to be leading to recovering turtle populations.

Although variable, there has been clear advancement towards the key research questions identified by Hamann et al. (2010), whether we look at the systematic review of 2 recent years of publications or the integrated expert opinion of contributing authors. As yet under-resesearched are those relating to reproductive biology (Q1-3), threats (Q12-16) and conservation strategies (see Q17-20). Some of these biases may have been less marked if we had incorporated non-peer-reviewed literature and/or non-English literature sources. Additionally, no proactive effort was made to promote the 20 key questions, other than Open Access publication which may have lessened the impact of the exercise.

Compiling this critical review has highlighted that it may be timely to undertake one or more new prioritizing exercises. For this work to have maximal benefit we make the following recommendations that echo those of the original exercise.

\section{A need for a far greater engagement with social sciences}

Although the field of conservation has traditionally been dominated by natural scientists-primarily conservation biologists and ecologists-calls for increased engagement with social sciences from those within and external to the field are now 'routine' (Bennett et al. 2016) and have been directed to sea turtle conservation specifically (Frazier 2005, Campbell 2010). Yet, as this paper reveals, the tendency to prioritize biological questions remains. Although this prioritization reflects both 'who' participated in the original question setting and in this review of progress, and 'how' the review of progress was conceptualized, it also likely reflects 2 related realities: (1) sea turtle conservation remains dominated by natural scientists, (2) integration of natural and social sciences is difficult, both generally (Sandbrook et al. 2013, Bennett et al. 2016) and for sea turtle conservation, specifically (Campbell 2007).

However, if we accept that natural science alone is 'insufficient to find solutions to complex conservation problems that have social dimensions' (Sandbrook et al. 2013, p. 1488), then we need to tackle, rather than shy away from, these difficulties. Social science research 'for' sea turtle conservation-defined as research that strives to enhance conservation by studying, for example, how humans interact with and impact on biodiversity, and how individuals or communities can be motivated or incentivised to reduce negative impacts or contribute directly to conservation (cf. Sandbrook et al. 2013) — is evident in this review, but we need more of it. Furthermore, most of the existing research 'for' conservation is directed at specific field sites or conservation projects. Although it is essential to understand the history, culture, politics and economics of people and communities who interact with sea turtles in particular places, there is also a need for work at broader scales or on general policies that influence these place-specific outcomes, 
i.e. to understand how decisions are made, policies formulated and finally translated into practice. For example, how do new national or regional policies in support of other sectors or goals-e.g. tourism, poverty reduction, fisheries reform, port development, coastal resilience-interact with or impact existing formal and informal institutions for sea turtle conservation and management? Current quantitative frameworks such as network analyses and graphical models provide both an approach to understand these processes as well as tools for effective decision and practice.

Social science research 'on' conservation 'studies the conservation movement itself as a social phenomenon' (Sandbrook et al. 2013, p. 1488) and is less evident in this review (e.g. Campbell 2012, Liles et al. 2014). Research 'on' conservation is often met with hostility by conservationists, seen as counter-productive to their interests. However, Sandbrook et al. (2013, p. 1489) argue that conservation professionals need to 'understand themselves as a community with particular interests, habits, and characteristics', and understand 'the political and economic processes that not only affect the state of the natural world, but also frame and constitute the work of conservation organizations themselves' (p. 1489). This kind of research may prove particularly important if and when conservation biologists and practitioners have to reorient their activities and priorities in the face of recovering sea turtle populations, as referenced in several sections above.

After over 50 years of orienting activities around the perceived threat of extinction, how will existing institutions for sea turtle conservation be transformed and remain relevant in the face of recovered populations? The response of scientists, volunteers, local residents, and conservation professionals and governments (local, state, and federal) invested in a particular vision of sea turtle conservation will have important impacts for the sustainability of existing institutions and/or the emergence of new ones.

\section{Widening the pool of contributors}

As pointed out in Hamann et al. (2010) future exercises would benefit from a wider range of stakeholders consulted and involved in generating questions, and weighting their importance. This would include more management and policy professionals, governmental environmental resource managers and practioners from industrial sectors that interface with turtle conservation, e.g. fisheries, port development, tourism, petrochemicals, government agencies and legal experts. Such engagement would help identify research needs for specific conservation problems, such as testing gear modifications to reduce bycatch of sea turtles (e.g. Murray 2015) or policy innovation. Including stakeholders from a wider array of countries will help ensure that a diversity of issues and approaches to research and sea turtle conservation is included in this type of assessment. It should also help avoid a biased emphasis on sea turtle issues that are experienced by certain regions or research groups that tend to be over-represented in the published literature (Fig. 2).

\section{Focussing the questions}

In undertaking this appraisal, it became clear that the focus of the questions generated in the first exercise was not precise enough. Any subsequent prioritizing exercise would need to develop more specific and discrete questions, even if it means they are not so easily prioritized into a 'top 20 '. The considerable overlap among the questions became obvious as they were reviewed, and there are clearly emerging themes which could be more effectively highlighted in any new exercise. Given the biases outlined above it is likely that we should disentangle ecology from conservation (see Sutherland et al. 2006, 2009). A further step forward could be improving the connection between the priority research questions and priority conservation actions; moving from a qualitative to a quantitative assessment of how the field is heading. Finally, a concerted effort should be made to publicize resultant prority questions and enhance their impact.

Acknowledgements. Zara Botterell helped with project administration and we acknowledge the support and insight of 3 anonymous referees. K.R.W-S is supported by the National Science Foundation Graduate Research Fellowship under Grant No. DGE-1252521. Any opinion, findings, and conclusions or recommendations expressed in this material are those of the authors and do not necessarily reflect the views of the National Science Foundation. Mention of products and trade names do not imply endorsement by the US Government.

\section{LITERATURE CITED}

Abd Mutalib AH, Fadzly N (2015) Assessing hatchery management as a conservation tool for sea turtles: a case study in Setiu, Terengganu. Ocean Coast Manage 113:47-53

Abella Perez E, Marco A, Martins S, Hawkes LA (2016) Is this what a climate change-resilient population of marine turtles looks like? Biol Conserv 193:124-132 
Abreu-Grobois A, Plotkin P (2008) (IUCN SSC Marine Turtle Specialist Group). 2008. Lepidochelys olivacea. The IUCN Red List of Threatened Species 2008: e.T11534 A3292503. http://dx.doi.org/10.2305/IUCN.UK.2008.RLTS. T11534A3292503.en (accessed 1 November 2016)

Ackerman R (1997) The nest environment and the embryonic development of sea turtles. In: Lutz P, Musick J (eds) The biology of sea turtles. CRC Press, Boca Raton, FL, p 83-106

Ackermann M, Koriabine M, Hartmann-Fritsch F, de Jong PJ and others (2012) The genome of chelonid Herpesvirus 5 harbors atypical genes. PLOS ONE 7:e46623

Adimey NM, Hudak CA, Powell JR, Bassos-Hull K and others (2014) Fishery gear interactions from stranded bottlenose dolphins, Florida manatees and sea turtles in Florida, USA. Mar Pollut Bull 81:103-115

Aguilar-González ME, Luna-González L, Aguirre A, ZavalaNorzagaray A, Mundo-Ocampo M, González Ocampo HA (2014) Perceptions of fishers to sea turtle bycatch, illegal capture and consumption in the San IgnacioNavachiste-Macapule lagoon complex, Gulf of California, Mexico. Integr Zool 9:70-84

Aguirre AA, Lutz PL (2004) Marine turtles as sentinels of ecosystem health: Is fibropapillomatosis an indicator? EcoHealth 1:275-283

Akçakaya HR (2000) Population viability analyses with demographically and spatially structured models. Ecol Bull 48:23-38

Al-Mohanna SY, Al-Zaidan ASY, George P (2014) Green turtles (Chelonia mydas) of the north-western Arabian Gulf, Kuwait: the need for conservation. Aquat Conserv Freshw Ecosyst 24:166-178

Alava JJ, Keller JM, Wyneken J, Crowder L, Scott G, Kucklick JR (2011) Geographical variation of persistent organic pollutants in eggs of threatened loggerhead sea turtles (Caretta caretta) from south eastern United States. Environ Toxicol Chem 30:1677-1688

Alessandro L, Antonello S (2010) An overview of loggerhead sea turtle (Caretta caretta) bycatch and technical mitigation measures in the Mediterranean Sea. Rev Fish Biol Fish 20:141-161

Alfaro-Núñez A, Gilbert MT (2014) Validation of a sensitive PCR assay for the detection of Chelonid fibropapillomaassociated herpesvirus in latent turtle infections. J Virol Methods 206:38-41

Alfaro-Núñez A, Bertelsen MF, Bojesen AM, Rasmussen I and others (2014) Global distribution of Chelonid fibropapilloma-associated herpesvirus among clinically healthy sea turtles. BMC Evol Biol 14:206

Alfaro-Núñez A, Jensen MP, Abreu-Grobois FA (2015) Does polyandry really pay off? The effects of multiple mating and number of fathers on morphological traits and survival in clutches of nesting green turtles at Tortuguero. PeerJ 3:e880

Alfaro-Núñez A, Bojesen AM, Bertelsen MF, Wales N, Balazs GH, Gilbert MT (2016) Further evidence of Chelonid herpesvirus 5 (ChHV5) latency: high levels of ChHV5 DNA detected in clinically healthy marine turtles. PeerJ 4:e2274

*Alfaro-Shigueto J, Mangel JC, Pajuelo M, Dutton PH, Seminoff JA, Godley BJ (2010) Where small can have a large impact: structure and characterization of small-scale fisheries in Peru. Fish Res 106:8-17

Alfaro-Shigueto J, Mangel JC, Bernedo F, Dutton PH, Seminoff JA, Godley BJ (2011) Small-scale fisheries of Peru: a major sink for marine turtles in the Pacific. J Appl Ecol 48:1432-1440.

* Alfaro-Shigueto J, Mangel JC, Dutton PH, Seminoff JA, Godley BJ (2012) Trading information for conservation: a novel use of radio broadcasting to reduce sea turtle bycatch. Oryx 46:332-339

* Allen ZC, Shah NJ, Grant A, Derand GD, Bell D (2010) Hawksbill turtle monitoring in Cousin Island, Seychelles: an eight-fold increase in annual nesting numbers. Endang Species Res 11:195-200

Allen CD, Robbins MN, Eguchi T, Owens DW and others (2015) First assessment of the sex ratio for an East Pacific green sea turtle foraging aggregation: validation and application of a testosterone ELISA. PLOS ONE 10:e0138861

* Álvarez de Quevedo I, San Félix M, Cardona L (2013) Mortality rates in by-caught loggerhead turtle Caretta caretta in the Mediterranean Sea and implications for the Atlantic populations. Mar Ecol Prog Ser 489:225-234

* Álvarez de Quevedo I, San Félix M, Cardona L (2014) Temporal trends in the by-catch of loggerhead turtle Caretta caretta in the Mediterranean Sea: Reply to Báez et al. (2014). Mar Ecol Prog Ser 504:303-304

Amorim S, Santos MN, Coelho R, Fernandez-Carvalho J (2015) Effects of 17/0 circle hooks and bait on fish catches in a Southern Atlantic swordfish longline fishery. Aquat Conserv Freshw Ecosyst 25:518-533

Anastácio R, Santos C, Lopes C, Moreira H and others (2014) Reproductive biology and genetic diversity of the green turtle (Chelonia mydas) in Vamizi island, Mozambique. Springerplus 3:art540

Arena PC, Warwick C, Steedman C (2014) Welfare and environmental implications of farmed sea turtles. J Agric Environ Ethics 27:309-330

Arendt MD, Segars AL, Byrd JI, Boynton J, Schwenter JA, Whitaker JD, Parker L (2012a) Migration, distribution, and diving behaviour of adult male loggerhead sea turtles (Caretta caretta) following dispersal from a major breeding aggregation in the Western North Atlantic. Mar Biol 159:113-125

Arendt MD, Segars AL, Byrd JI, Boynton J and others (2012b) Distributional patterns of adult male loggerhead sea turtles (Caretta caretta) in the vicinity of Cape Canaveral, Florida, USA during and after a major annual breeding aggregation. Mar Biol 159:101-112

* Arthur KE, Limpus CJ, Roelfsema CM, Udy JW, Shaw GR (2006) A bloom of Lyngbya majuscula in Shoalwater Bay, Queensland, Australia: an important feeding ground for the green turtle (Chelonia mydas). Harmful Algae 5: 251-265

* Arthur KE, Limpus CJ, Whittier JM (2008) Baseline blood biochemistry of Australian green turtles (Chelonia mydas) and effects of exposure to the toxic cyanobacterium Lyngbya majuscula. Aust J Zool 56:23-32

Ascani F, Van Houtan KS, Di Lorenzo M, Polovina JJ, Jones JJ (2016) Juvenile recruitment in loggerhead sea turtles linked to decadal changes in ocean circulation. Glob Change Biol 22:3529-3538. doi:10.1111/gcb.13331

* Attum O, Kramer A, Mahmoud T, Fouda M (2014) Post-nesting migrations patterns of green turtles (Chelonia mydas) from the Egyptian Red Sea. Zool Middle East 60:299-305

Avens L, Taylor JC, Goshe LR, Jones TT, Hastings M (2009) Use of skeletochronological analysis to estimate the age of leatherback sea turtles Dermochelys coriacea in the western North Atlantic. Endang Species Res 8:165-177

Avens L, Goshe LR, Pajuelo M, Bjorndal KA and others 
(2013) Complementary skeletochronology and stable isotope analyses offer new insight into juvenile loggerhead sea turtle oceanic stage duration and growth dynamics. Mar Ecol Prog Ser 491:235-251

Avens L, Goshe LR, Coggins L, Snover ML, Pajuelo M, Bjorndal KA, Bolten AB (2015) Age and size at maturation- and adult-stage duration for loggerhead sea turtles in the western North Atlantic. Mar Biol 162:1749-1767

* Ayala L, Sanchez-Scaglioni R (2014) Catch, effort and bycatch of longline fishery in central Peru. Rev Peru Biol 21:243-250

Ayissi I, Aksissou M, Tiwari M, Fretey J (2015) Descriptive study of artisanal fisheries and their impact on sea turtles within the future marine national park of Manyange na Elombo Campo (Cameroon, Gulf of Guinea). Bull Soc Herpetol Fr 156:15-30

* Baena ML, Escobar F, Halffter G, García-Chávez JH (2015) Distribution and feeding behavior of Omorgus suberosus (Coleoptera: Trogidae) in Lepidochelys olivacea turtle nests. PLOS ONE 10:e0139538

Báez JC, García-Barcelona S, Real R, Macias D (2014a) Estimating by-catch of loggerhead turtles in the Mediterranean: Comment on Álvarez de Quevedo et al. (2013) Mar Ecol Prog Ser 504:301-302

Báez JC, Macías D, García-Barcelona S, Real R (2014b) Interannual differences for sea turtles bycatch in Spanish longliners from Western Mediterranean Sea. SciWorld J 2014:861396

Baker L, Edwards W, Pike DA (2015) Sea turtle rehabilitation success increases with body size and differs among species. Endang Species Res 29:13-21

Balazs G, Parker D, Gorman J, Luecke J, Pawloski J (2015a) Settling down in Hawaii: adaptation of captive-bred green turtles (Chelonia mydas) released from the Maui Ocean Center. Mar Turtle Newsl 145:22-26

Balazs GH, Van Houtan KS, Hargrove SA, Brunson SM, Murakawa SK (2015b) A review of the demographic features of Hawaiian green turtles (Chelonia mydas). Chelonian Conserv Biol 14:119-129

Balderson SD, Martin LEC (2015) Environmental impacts and causation of 'beached' drifting fish aggregating devices around Seychelles Islands: a preliminary report on data collected by Island Conservation Society. Indian Ocean Tuna Commission 2015 WPEB 11 WD39. www. iotc.org/sites/default/files/documents/2015/09/IOTC2015-WPEB11-39_-_FAD_beaching_Seychelles.pdf

* Barik SK, Mohanty PK, Kar PK, Behera B, Patra SK (2014) Environmental cues for mass nesting of sea turtles. Ocean Coast Manage 95:233-240

Barreiros JP, Raykov VS (2014) Lethal lesions and amputation caused by plastic debris and fishing gear on the loggerhead turtle Caretta caretta (Linnaeus, 1758). Three case reports from Terceira Island, Azores (NE Atlantic). Mar Pollut Bull 86:518-522

* Barron MG (2012) Ecological impacts of the Deepwater Horizon oil spill: implications for immunotoxicity. Toxicol Pathol 40:315-320

Baudouin M, de Thoisy B, Chambault P, Berzins R and others (2015) Identification of key marine areas for conservation based on satellite tracking of post-nesting migrating green turtles (Chelonia mydas). Biol Conserv 184: 36-41

Bell CDL, Parsons J, Austin TJ, Broderick AC, Ebanks-Petrie G, Godley BJ (2005) Some of them came home: the Cayman Turtle Farm headstarting project for the green turtle
Chelonia mydas. Oryx 39:137-148

Bennett NJ, Roth R, Klain SC, Chan KMA and others (2016) Mainstreaming the social sciences in conservation. Conserv Biol. doi:10.1111/cobi.12788

Benson SR, Eguchi T, Foley DG, Forney KA and others (2011) Large-scale movements and high-use areas of western Pacific leatherback turtles, Demochelys coriacea. Ecosphere 2:art84

* Berry M, Booth DT, Limpus CJ (2013) Artificial lighting and disrupted sea-finding behaviour in hatchling loggerhead turtles (Caretta caretta) on the Woongarra coast, southeast Queensland, Australia. Aust J Zool 61:137-145

Bevan E, Wibbels T, Najera BMZ, Martinez MAC and others (2014) In situ nest and hatchling survival at Rancho Nuevo, the primary nesting beach of the Kemp's ridley sea turtle, Lepidochelys kempii. Herpetol Conserv Biol 9:563-577

*Bézy VS, Valverde RA, Plante CJ (2015) Olive ridley sea turtle hatching success as a function of the microbial abundance in nest sand at Ostional, Costa Rica. PLOS ONE 10:e0118579

Bhatpuria D, Solanki HU, Varghese S, Chauhan P (2015) Applications of satellite derived meso-scale features and in-situ bycatch to understand sea turtle habitats along the Indian Coast. Curr Sci 108:326-329

Bjorndal KA, Bolten AB (2003) From ghosts to key species: restoring sea turtle populations to fulfill their ecological roles. Mar Turtle Newsl 100:16-21

Bjorndal KA, Jackson JBC (2003) Roles of sea turtles in marine ecosystems: reconstructing the past. In: Lutz PL, Musick JA, Wyneken J (eds) The biology of sea turtles. CRC Press, Boca Raton, FL, p 259-273

Bjorndal KA, Bowen BW, Chaloupka M, Crowder LB and others (2011) Better science needed for restoration in the Gulf of Mexico. Science 331:537-538

* Bjorndal KA, Parsons J, Mustin W, Bolten AB (2014) Variation in age and size at sexual maturity in Kemp's ridley sea turtles. Endang Species Res 25:57-67

* Bjorndal KA, Chaloupka M, Saba VS, Diez CE and others (2016) Somatic growth dynamics of West Atlantic hawksbill sea turtles: a spatio-temporal perspective. Ecosphere $7: \mathrm{e} 01279$

*Banco GS, Morreale SJ, Vélez E, Piedra R, Montes WM, Paladino FV, Spotila JR (2012) Reproductive output and ultrasonography of an endangered population of east pacific green turtles. J Wildl Manag 76:841-846

Bostwick A, Higgins BM, Landry AM, McCraken ML (2014) Novel use of a shark model to elicit innate behavioral responses in sea turtles: application to bycatch reduction in commercial fisheries. Chelonian Conserv Biol 13: $237-246$

*Bouchard SS, Bjorndal KA (2000) Sea turtles as biological transporters of nutrients and energy from marine to terrestrial ecosystems. Ecology 81:2305-2313

Bourjea J, Clermont S, Delgado A, Murua H, Ruiz J, Ciccione S, Chavance P (2014) Marine turtle interaction with purse-seine fishery in the Atlantic and Indian oceans: lessons for management. Biol Conserv 178:74-87

* Bourjea J, Mortimer JA, Garnier J, Okemwa G and others (2015a) Population structure enhances perspectives on regional management of the western Indian Ocean green turtle. Conserv Genet 16:1069-1083

Bourjea J, Dalleau M, Derville S, Beudard F and others (2015b) Seasonality, abundance, and fifteen-year trend in green turtle nesting activity at Itsamia, Moheli, 
Comoros. Endang Species Res 27:265-276

Bovery CM, Wyneken J (2015) Seasonal variation in sea turtle density and abundance in the southeast Florida Current and surrounding waters. PLOS ONE 10:e0145980

Bowen BW, Gaither MR, DiBattista JD, Iacchei M and others (2016) Comparative phylogeography of the ocean planet. Proc Natl Acad Sci USA 113:7962-7969

Boyle M, Schwanz LE, Hone J, Georges A (2014) How do climate-linked sex ratios and dispersal limit range boundaries? BMC Ecol 14:19

Braga HO, Schiavetti A (2013) Attitudes and local ecological knowledge of expert fishermen in relation to conservation and bycatch of sea turtles (Reptilia: Testudines), Southern Bahia, Brazil. J Ethnobiol Ethnomed 9:15

Braun-McNeill J, Epperly SP, Owens DW, Avens LA, Williams E, Harms CA (2007) Seasonal reliability of testosterone radioimmunoassay (RIA) for predicting sex ratios of juvenile loggerhead (Caretta caretta) turtles. Herpetologica 63:275-284

Bresette MJ, Witherington BE, Herren RM, Bagley DA and others (2010) Size-class partitioning and herding in a foraging group of green turtles Chelonia mydas. Endang Species Res 9:105-116

Briscoe DK, Parker DM, Balazs GH, Kurita M and others (2016) Active dispersal in loggerhead sea turtles (Caretta caretta) during the 'lost years'. Proc R Soc B 283: 20160690

Brost B, Witherington B, Meylan A, Leone E, Ehrhart L, Bagley D (2015) Sea turtle hatchling production from Florida (USA) beaches, 2002-2012, with recommendations for analyzing hatching success. Endang Species Res 27:53-68

Brothers JR, Lohmann KJ (2015) Evidence for geomagnetic imprinting and magnetic navigation in the natal homing of sea turtles. Curr Biol 25:392-396

Brunner CH, Dutra G, Silva CB, Silveira LM, Martins M de F (2014) Electrochemotherapy for the treatment of fibropapillomas in Chelonia mydas. J Zoo Wildl Med 45:213-218

Bucchia M, Camacho M, Santos M, Boada L and others (2015) Plasma levels of pollutants are much higher in loggerhead turtle populations from the Adriatic Sea than in those from open waters (Eastern Atlantic Ocean). Sci Total Environ 523:161-169

Burger J, Gochfeld M (2014) Avian predation on olive ridley (Lepidochelys olivacea) sea turtle eggs and hatchlings: avian opportunities, turtle avoidance, and human protection. Copeia 2014:109-122

Burkholder DA, Heithaus MR, Fourqurean JW, Wirsing A, Dill LM (2013) Patterns of top-down control in a seagrass ecosystem: Could a roving apex predator induce a behaviour-mediated trophic cascade? J Anim Ecol 82: 1192-1202

Butler JR, Tawake A, Skewes T, Tawake L, McGrath V (2012) Integrating traditional ecological knowledge and fisheries management in the Torres Strait, Australia: the catalytic role of turtles and dugong as cultural keystone species. Ecol Soc 17:1-9

Caillouet CW Jr (2014) Interruption of the Kemp's ridley population's pre-2010 exponential growth in the Gulf of Mexico and its aftermath: one hypothesis. Mar Turtle Newsl 143:1-7

Caillouet CW Jr, Shaver DJ, Landry Andre MJ (2015) Kemp's ridley sea turtle (Lepidochelys kempii) headstart and reintroduction to Padre Island National Seashore, Texas. Herpetol Conserv Biol 10:309-377
Caliani I, Campani T, Giannetti M, Marsili L, Casini S, Fossi MC (2014) First application of comet assay in blood cells of Mediterranean loggerhead sea turtle (Caretta caretta). Mar Environ Res 96:68-72

Calvillo Garcia Y, Ramirez-Herrera MT, Delgado-Trejo C, Legorreta-Paulin G, Corona N (2015) Modeling sea-level change, inundation scenarios, and their effect on the Colola Beach Reserve - a nesting-habitat of the black sea turtle, Michoacán, Mexico. Geofis Int 54:179-190

Camacho M, Luzardo O, Boada L, Jurado L, Medina M, Zumbado M, Orós J (2013a) Potential adverse health effects of persistent organic pollutants on sea turtles: evidences from a cross-sectional study on Cape Verde loggerhead sea turtles. Sci Total Environ 458-460:283-289

Camacho M, Boada L, Orós J, López P, Zumbado M, Almeida-González M, Luzardo O (2013b) Comparative study of organohalogen contamination between two populations of eastern Atlantic loggerhead sea turtles (Caretta caretta). Bull Environ Contam Toxicol 91: 678-683

Camacho M, Orós J, Boada LD, Zaccaroni A and others (2013c) Potential adverse effects of inorganic pollutants on clinical parameters of loggerhead sea turtles (Caretta caretta): results from a nesting colony from Cape Verde, West Africa. Mar Environ Res 92:15-22

* Camedda A, Marra S, Matiddi M, Massaro G and others (2014) Interaction between loggerhead sea turtles (Caretta caretta) and marine litter in Sardinia (Western Mediterranean Sea). Mar Environ Res 100:25-32

Campbell LM (1998) Use them or lose them? Conservation and the consumptive use of marine turtle eggs at Ostional, Costa Rica. Environ Conserv 25:305-319

Campbell LM (2007) Local conservation practice and global discourse: a political ecology of sea turtle conservation. Ann Assoc Am Geogr 97:313-334

Campbell LM (2010) Studying sea turtle conservation and learning about the world: perspectives from social sciences. Conserv Soc 8:1-4

Campbell LM (2012) Seeing red: inside the science and politics of IUCN Red Lists. Conserv Soc 10:367-380

Campbell CL, Lagueux CJ (2005) Survival probability estimates for large juvenile and adult green turtles (Chelonia mydas) exposed to an artisanal marine turtle fishery in the western Caribbean. Herpetologica 61:91-103

* Campbell LM, Haalboom BJ, Trow J (2007) Sustainability of community-based conservation: sea turtle egg harvesting in Ostional (Costa Rica) ten years later. Environ Conserv 34:122-131

Capper A, Flewelling LJ, Arthur K, Garcia AC (2013) Dietary exposure to harmful algal bloom (HAB) toxins in the endangered manatee (Trichechus manatus latirostris) and green sea turtle (Chelonia mydas) in Florida, USA. Harmful Algae 28:1-9

Cardona L, Clusa M, Eder E, Demetropoulos A and others (2014) Distribution patterns and foraging ground productivity determine clutch size in Mediterranean loggerhead turtles. Mar Ecol Prog Ser 497:229-241

Cardona L, Martínez-Iñigo L, Mateo R, González-Solís J (2015) The role of sardine as prey for pelagic predators in the western Mediterranean Sea assessed using stable isotopes and fatty acids. Mar Ecol Prog Ser 531:1-14

Carpenter SR, Caraco NF, Correll DL, Howarth RW, Sharpley AN, Smith VH (1998) Nonpoint pollution of surface waters with phosphorus and nitrogen. Ecol Appl 8: $559-568$ 
Carreras C, Monzón-Argüello C, Felipe Lopez-Jurado L, Calabuig $\mathrm{P}$ and others (2014a) Origin and dispersal routes of foreign green and Kemp's ridley turtles in Spanish Atlantic and Mediterranean waters. Amphibreptil 35:73-86

Carreras C, Rees AF, Broderick AC, Godley BJ, Margaritoulis D (2014b) Mitochondrial DNA markers of loggerhead marine turtles (Caretta caretta) (Testudines: Cheloniidae) nesting at Kyparissia Bay, Greece, confirm the western Greece unit and regional structuring. Sci Mar 78:115-124

de Carvalho RH, Lacerda PD, Mendes S da S, Barbosa BC, Paschoalini M, Prezoto F, de Sousa BM (2015) Marine debris ingestion by sea turtles (Testudines) on the Brazilian coast: an underestimated threat? Mar Pollut Bull 101:746-749

* Casale P (2011) Sea turtle by-catch in the Mediterranean? Fish Fish 12:299-316

Casale P, Heppell SS (2016) How much sea turtle bycatch is too much? A stationary age distribution model for simulating population abundance and potential biological removal in the Mediterranean. Endang Species Res 29:239-254

Casale P, Mariani P (2014) The first 'lost year' of Mediterranean sea turtles: dispersal patterns indicate subregional management units for conservation. Mar Ecol Prog Ser 498:263-274

* Casale P, Lazar B, Pont S, Tomás J and others (2006) Sex ratios of juvenile loggerhead sea turtles Caretta caretta in the Mediterranean Sea. Mar Ecol Prog Ser 324: 281-285

* Casale P, Aprea A, Deflorio M, De Metrio G (2012) Increased by-catch rates in the Gulf of Taranto, Italy, in 20 years: A clue about sea turtle population trends? Chelonian Conserv Biol 11:239-243

Casale P, Freggi D, Cinà A, Rocco M (2013) Spatio-temporal distribution and migration of adult male loggerhead sea turtles (Caretta caretta) in the Mediterranean Sea: further evidence of the importance of neritic habitats off North Africa. Mar Biol 160:703-718

* Casale P, Freggi D, Maffucci F, Hochscheid S (2014) Adult sex ratios of loggerhead sea turtles (Caretta caretta) in two Mediterranean foraging grounds. Sci Mar 78: 303-309

Casale P, Freggi D, Furii G, Vallini C and others (2015) Annual survival probabilities of juvenile loggerhead sea turtles indicate high anthropogenic impact on Mediterranean populations. Aquat Conserv Freshw Ecosyst 25:690-700

Casale P, Freggi D, Paduano V, Oliverio M (2016) Biases and best approaches for assessing debris ingestion in sea turtles, with a case study in the Mediterranean. Mar Pollut Bull 110:238-249

Cavallo C, Dempster T, Kearney MR, Kelly E, Booth D, Hadden KM, Jessop TS (2015) Predicting climate warming effects on green turtle hatchling viability and dispersal performance. Funct Ecol 29:768-778

Ceriani SA, Roth JD, Evans DR, Weishampel JF, Ehrhart LM (2012) Inferring foraging areas of nesting loggerhead turtles using satellite telemetry and stable isotopes. PLOS ONE 7:e45335

Ceriani SA, Roth JD, Tucker AD, Evans DR and others (2015) Carry-over effects and foraging ground dynamics of a major loggerhead breeding aggregation. Mar Biol 162:1955-1968
Chaloupka MY, Musick JA (1997) Age, growth, and population dynamics. In: Lutz PL, Musick JA (eds) The biology of sea turtles. CRC Press, Boca Raton, FL, p 233-276

Chaloupka M, Bjorndal KA, Balazs GH, Bolten AB and others (2008) Encouraging outlook for recovery of a once severely exploited marine megaherbivore. Glob Ecol Biogeogr 17:297-304

Charnier M (1966) Action de la température sur la sex-ratio chez l'embryon d'Agama agama (Agamidae, Lacertilien). C R Seances Soc Biol Fil 160:620-622

Charnov EL, Bull JJ (1977) When is sex environmentally determined? Nature 266:828-830

Chaves LB, Berrocal A, Meneses AI, Sánchez CJ, Orrego Vásquez CM (2013) Study on the etiology of fibropapillomatosis of olive ridley sea turtles (Lepidochelys olivacea) nesting in the National Wildlife Refuge at Ostional, Guanacaste, Costa Rica. Revista Marina Costera 5:119-134

* Cheng IJ, Lin CH, Tseng CT (2015) Factors influencing variations of oxygen content in nests of green sea turtles during egg incubation with a comparison of two nesting environments. J Exp Mar Biol Ecol 471:104-111

* Choy CA, Popp BN, Hannides CCS, Drazen JC (2015) Trophic structure and food resources of epipelagic and mesopelagic fishes in the North Pacific Subtropical Gyre ecosystem inferred from nitrogen isotopic compositions. Limnol Oceanogr 60:1156-1171

* Christianen MJA, Herman PMJ, Bouma TJ, Lamers LPM and others (2014) Habitat collapse due to overgrazing threatens turtle conservation in marine protected areas. Proc R Soc B 281:20132890

Christie P, Campbell LM, Armada N (2014) Stewardship in tropical small-scale fisheries: community and national perspectives. In: Garcia S, Rice J, Charles T (eds) Governance of marine fisheries and biodiversity conservation: interaction and co-evolution. Wiley-Blackwell, London, p 332-345

Clusa M, Carreras C, Pascual M, Gaughran SJ and others (2014) Fine-scale distribution of juvenile Atlantic and Mediterranean loggerhead turtles (Caretta caretta) in the Mediterranean Sea. Mar Biol 161:509-519

Cocci P, Bracchetti L, Angelini V, Bucchia M and others (2014) Development and pre-validation of a testosterone enzyme immunoassay (EIA) for predicting the sex ratio of immature loggerhead sea turtles (Caretta caretta) recovered along the western coast of the central Adriatic Sea. Mar Biol 161:165-171

* Coelho R, Santos MN, Fernandez-Carvalho J, Amorim S (2015) Effects of hook and bait in a tropical northeast Atlantic pelagic longline fishery. I. Incidental sea turtle bycatch. Fish Res 164:302-311

Colman LP, Patrício ARC, McGowan A, Santos AJB, Marcovaldi MÂ, Bellini C, Godley BJ (2015) Long-term growth and survival dynamics of green turtles (Chelonia mydas) at an isolated tropical archipelago in Brazil. Mar Biol 162:111-122

* Cooke SJ, Danylchuk AJ, Kaiser MJ, Rudd MA (2010) Is there a need for a '100 questions exercise' to enhance fisheries and aquatic conservation, policy, management and research? Lessons from a global 100 questions exercise on conservation of biodiversity. J Fish Biol 76: 2261-2286

Cracknell D, White MP, Pahl P, Nichols WJ, Depledge MH (2016) Marine biota and psychological well-being: a preliminary examination of dose-response effects in an aquarium setting. Environ Behav 48:1242-1269 
Crear DP, Lawson DD, Seminoff JA, Eguchi T, LeRoux RA, Lowe CG (2016) Seasonal shifts in the movement and distribution of green sea turtles Chelonia mydas in response to anthropogenically altered water temperatures. Mar Ecol Prog Ser 548:219-232

Crouse DT, Crowder LB, Caswell H (1987) A stage-based population model for loggerhead sea turtles and implications for conservation. Ecology 68:1412-1423

* Curtis KA, Moore JE, Boyd C, Dillingham PW, Lewison RL, Taylor BL, James KC (2015a) Managing catch of marine megafauna: guidelines for setting limit reference points. Mar Policy 61:249-263

* Curtis KA, Moore JE, Benson SR (2015b) Estimating limit reference points for western Pacific leatherback turtles (Dermochelys coriacea) in the U.S. west coast EEZ. PLOS ONE 10:e0136452

* D'Cruze N, Alcock R, Donnelly M (2015) The Cayman Turtle Farm: why we can't have our green turtle and eat it too. J Agric Environ Ethics 28:57-66

da Silva CC, Klein RD, Barcarolli IF, Bianchini A (2016) Metal contamination as a possible etiology of fibropapillomatosis in juvenile female green sea turtles Chelonia mydas from the southern Atlantic Ocean. Aquat Toxicol 170:42-51

da Silva Mendes S, de Carvalho RH, de Faria AF, de Sousa BM (2015) Marine debris ingestion by Chelonia mydas (Testudines: Cheloniidae) on the Brazilian coast. Mar Pollut Bull 92:8-10

Dalleau M, Benhamou S, Sudre J, Ciccione S, Bourjea J (2014) The spatial ecology of juvenile loggerhead turtles (Caretta caretta) in the Indian Ocean sheds light on the 'lost years' mystery. Mar Biol 161:1835-1849

* Daza-Criado L, Hernandez-Fernandez J (2014) Molecular identification and first report of mitochondrial COI gene haplotypes in the hawksbill turtle Eretmochelys imbricata (Testudines: Cheloniidae) in the Colombian Caribbean nesting colonies. Genet Mol Res 13:7123-7132

dei Marcovaldi MAG, Santos AJB, Santos AS, Soares LS, Lopez GG, Godfrey MH, Lopez-Mendilaharsu M, Fuentes MMPB (2014) Spatio-temporal variation in the incubation duration and sex ratio of hawksbill hatchlings: implication for future management. J Therm Biol 44:70-77

* Delcroix E, Bédel S, Santelli G, Girondot M (2014) Monitoring design for quantification of marine turtle nesting with limited effort: a test case in the Guadeloupe archipelago. Oryx 48:95-105

* Delgado C, Valente A, Quaresma I, Costa M, Dellinger T (2011) Blood biochemistry reference values for wild juvenile loggerhead sea turtles (Caretta caretta) from Madeira archipelago. J Wildl Dis 47:523-529

* Dellert LJ, O'Neil D, Cassill DL (2014) Effects of beach renourishment and clutch relocation on the success of the loggerhead sea turtle (Caretta caretta) eggs and hatchlings. J Herpetol 48:186-187

Derville S, Jean C, Dalleau M, Le Gall JY, Ciccione S, Bourjea J (2015) Long-term monitoring of green turtle nesting on Tromelin Island demonstrates stable reproduction and population parameters. Chelonian Conserv Biol 14: $11-20$

*Dethmers KEM, Baxter PWJ (2011) Extinction risk analysis of exploited green turtle stocks in the Indo-Pacific. Anim Conserv 14:140-150

Dethmers KE, Broderick D, Moritz C, Fitzsimmons NN and others (2006) The genetic structure of Australasian green turtles (Chelonia mydas): exploring the geographical scale of genetic exchange. Mol Ecol 15:3931-3946

* Detjen M, Sterling E, Gomez A (2015) Stable isotopes in barnacles as a tool to understand green sea turtle (Chelonia mydas) regional movement patterns. Biogeosciences 12:7081-7086

* Deudero S, Alomar C (2015) Mediterranean marine biodiversity under threat: reviewing influence of marine litter on species. Mar Pollut Bull 98:58-68

* Deus Santos MRd, SilvaMartins A, Baptistotte C, Work TM (2015) Health condition of juvenile Chelonia mydas related to fibropapillomatosis in southeast Brazil. Dis Aquat Org 115:193-201

*Dewald JR, Pike DA (2014) Geographical variation in hurricane impacts among sea turtle populations. J Biogeogr 41:307-316

* Dickey M, Cray C, Norton T, Murray M and others (2014) Assessment of hemoglobin binding protein in loggerhead sea turtles (Caretta caretta) undergoing rehabilitation. J Zoo Wildl Med 45:700-703

* Dodge KL, Galuardi B, Miller TJ, Lutcavage ME (2014) Leatherback turtle movements, dive behavior, and habitat characteristics in ecoregions of the northwest Atlantic Ocean. PLOS ONE 9:e91726

*Domènech F, Álvarez de Quevedo I, Merchán M, Revuelta O and others (2015) Incidental catch of marine turtles by Spanish bottom trawlers in the western Mediterranean. Aquat Conserv 25:678-689

* Donnelly K, Waltzek TB, Wellehan JF Jr, Sutton DA, Wiederhold NP, Stacy BA (2015) Phaeohyphomycosis resulting in obstructive tracheitis in three green sea turtles Chelonia mydas stranded along the Florida coast. Dis Aquat Org 113:257-262

* Drew JA, Henne AP (2006) Conservation biology and traditional ecological knowledge: integrating academic disciplines for better conservation practice. Ecol Soc 11:34

* Duarte A, Faísca P, Loureiro NS, Rosado R and others (2012) First histological and virological report of fibropapilloma associated with herpesvirus in Chelonia mydas at Príncipe Island, West Africa. Arch Virol 157: 1155-1159

*Dudley PN, Porter WP (2014) Using empirical and mechanistic models to assess global warming threats to leatherback sea turtles. Mar Ecol Prog Ser 501:265-278

* Dunbar SG, Ito HE, Bahjri K, Dehom S, Salinas L (2014) Recognition of juvenile hawksbills Eretmochelys imbricata through face scale digitization and automated searching. Endang Species Res 26:137-146

Dunkin L, Reif M, Altman S, Swannack T (2016) A spatially explicit, multi-criteria decision support model for loggerhead sea turtle nesting habitat suitability: a remote sensing-based approach. Remote Sens 8:573

* Duran N, Dunbar SG, Escobar RA III, Standish TG (2015) High frequency of multiple paternity in a solitary population of olive ridley sea turtles in Honduras. J Exp Mar Biol Ecol 463:63-71

Dutton PH, Squires D (2011) A holistic strategy for Pacific sea turtle conservation. In: Dutton $\mathrm{PH}$, Squires D, Ahmed $\mathrm{M}$ (eds) Conservation of Pacific sea turtles. University of Hawaii Press, Honolulu, HI, p 37-59

Dutton PH, Stewart KR (2013) A method for sampling hatchling sea turtles for the development of a genetic tag. Mar Turtle Newsl 138:3-7

* Dutton DL, Dutton PH, Chaloupka M, Boulon R (2005) Increase of a Caribbean leatherback turtle Dermochelys 
coriacea nesting population linked to long-term nest protection. Biol Conserv 126:186-194

D Dutton PH, Roden SE, Stewart KR LaCasella E and others (2013) Population stock structure of leatherback turtles (Dermochelys coriacea) in the Atlantic revealed using mtDNA and microsatellite markers. Conserv Genet 14: 625-636

Dutton $\mathrm{PH}$, Jensen MP, Frutchey K, Frey A and others (2014a) Genetic stock structure of green turtle (Chelonia mydas) nesting populations across the Pacific islands. Pac Sci 68:451-464

Dutton PH, Jensen MP, Frey A, LaCasella EL and others (2014b) Population structure and phylogeography reveal pathways of colonization by a migratory marine reptile (Chelonia mydas) in the central and eastern Pacific. Ecol Evol 4:4317-4331

* Dyc C, Covaci A, Debier C, Leroy C, Delcroix E, Thomé JP, Das K (2015) Pollutant exposure in green and hawksbill marine turtles from the Caribbean region. Reg Stud Mar Sci 2:158-170

Ehrhart L, Redfoot W, Bagley D, Mansfield K (2014) Longterm trends in loggerhead (Caretta caretta) nesting and reproductive success at an important western Atlantic rookery. Chelonian Conserv Biol 13:173-181

Estabrook BJ, Ponirakis DW, Clark CW, Rice AN (2016) Widespread spatial and temporal extent of anthropogenic noise across the northeastern Gulf of Mexico shelf ecosystem. Endang Species Res 30:267-282

Esteban N, van Dam RP, Harrison E, Herrera A, Berkel J (2015) Green and hawksbill turtles in the Lesser Antilles demonstrate behavioural plasticity in inter-nesting behaviour and post-nesting migration. Mar Biol 162: 1153-1163

Fauquier DA, Flewelling LJ, Maucher J, Manire CA and others (2013) Brevetoxin in blood, biological fluids, and tissues of sea turtles naturally exposed to Karenia brevis blooms in central west Florida. J Zoo Wildl Med 44: 364-375

Fazey I, Fischer J, Lindenmayer D (2005) What do conservation biologists publish? Biol Conserv 124:63-73

Ferguson SD, Wellehan JF Jr, Frasca S Jr, Innis CJ, and others (2016) Coccidial infection of the adrenal glands of leatherback sea turtles (Dermochelys coriacea). J Wildl Dis 52:874-882

Fernandez I, Retamal MA, Mansilla M, Yanez F and others (2015) Analysis of epibiont data in relation with the debilitated turtle syndrome of sea turtles in Chelonia mydas and Lepidochelys olivacea from Concepcion coast, Chile. Lat Am J Aquat Res 43:1024-1029

Finlayson KA, Leusch FDL, van de Merwe JP (2016) The current state and future directions of marine turtle toxicology research. Environ Int 94:113-123

Fisher LR, Godfrey MH, Owens DW (2014) Incubation temperature effects on hatchling performance in the loggerhead sea turtle (Caretta caretta). PLOS ONE 9:e114880

FitzSimmons NN, Limpus CJ (2014) Marine turtle genetic stocks of the Indo-Pacific: identifying boundaries and knowledge gaps. Indian Ocean Turtle Newsl 20:2-18

Flaspohler DJ, Bub BR, Kaplin BA (2000) Application of conservation biology research to management. Conserv Biol 14:1898-1902

Flint M, Matthews BJ, Limpus CJ, Mills PC (2015a) Establishment of reference intervals for plasma protein electrophoresis in indo-pacific green sea turtles, Chelonia mydas. Conserv Physiol 3:cov037
Flint M, Eden PA, Limpus CJ, Owen H, Gaus C, Mills PC (2015b) Clinical and pathological findings in green turtles (Chelonia mydas) from Gladstone, Queensland: investigations of a stranding epidemic. EcoHealth 12:298-309

*Flores-Monter Y, Aceves-Quesada F, García-Romero A, Peters-Recagno EM (2015) Análisis multicriterio del impacto potencial del turismo en la anidación de las tortugas marinas en Chalacatepec, Jalisco. Nova Scientia $7: 644-673$

* Flower JE, Norton TM, Andrews KM, Nelson SE, Parker CE, Romero LM, Mitchell MA (2015) Baseline plasma corticosterone, haematological and biochemical results in nesting and rehabilitating loggerhead sea turtles (Caretta caretta). Conserv Physiol 3:cov003

Foley AM, Singel KE, Dutton PH, Summers TM, Redlow AE, Lessman J (2007) Characteristics of a green turtle (Chelonia mydas) assemblage in northwestern Florida determined during a hypothermic stunning event. Gulf Mex Sci 25:131-143

*Foley AM, Schroeder BA, Hardy R, MacPherson SL, Nicholas M (2014) Long-term behavior at foraging sites of adult female loggerhead sea turtles (Caretta caretta) from three Florida rookeries. Mar Biol 161:1251-1262

* Fonseca LA, Fagundes V, Girardi FM, Maia NL and others (2015) Plasma cholinesterase activity as environmental impact biomarker for green turtles (Chelonia mydas) on the coast of Fernando de Noronha, Pernambuco, Brazil. Pesqui Vet Bras 35:385-389

Fossette S, Hobson VJ, Girard C, Calmettes B, Gaspar P, Georges JY, Hays GC (2010) Spatio-temporal foraging patterns of a giant zooplanktivore, the leatherback turtle. J Mar Syst 81:225-234

Fossette S, Witt MJ, Miller P, Nalovic MA and others (2014) Pan-Atlantic analysis of the overlap of a highly migratory species, the leatherback turtle, with pelagic longline fisheries. Proc R Soc B 281:20133065

* Fourqurean JW, Manuel S, Coates KA, Kenworthy WJ, Smith SR (2010) Effects of excluding sea turtle herbivores from a seagrass bed: overgrazing may have led to loss of seagrass meadows in Bermuda. Mar Ecol Prog Ser 419: 223-232

Frans VF, Augé AA (2016) Use of local ecological knowledge to investigate endangered baleen whale recovery in the Falkland Islands. Biol Conserv 202:127-137

* Fraser DJ, Coon T, Prince MR, Dion R, Bernatchez L (2006) Integrating traditional and evolutionary knowledge in biodiversity conservation: a population level case study. Ecol Soc 11:4

Frazier J (1999) Community-based conservation. In: Eckert KL, Bjorndal KA, Abreu-Grobois FA, Donnelly M (eds) Research and management techniques for the conservation of sea turtles. IUCN/SSC Marine Turtle Specialist Group Publication No. 4, IUCN, Washington, DC, p 15-18

Frazier J (2005) Marine turtles: the role of flagship species in interactions between people and the sea. MAST 3(2) \& 4(1):5-38. http://www.marecentre.nl/mast/documents/ Mast-2004p.5-38.pdf

Frey A, Dutton PH, Shaver DJ, Walker JS, Rubio C (2014) Kemp's ridley Lepidochelys kempii nesting abundance in Texas, USA: a novel approach using genetics to improve population census. Endang Species Res 23:63-71

Fuentes MMPB, Bateman BL, Hamann M (2011a) Relationship between tropical cyclones and the distribution of sea turtle nesting grounds. J Biogeogr 38:1886-1896

F Fuentes MMPB, Limpus C, Hamann M (2011b) Vulnerabil- 
ity of sea turtle nesting grounds to climate change. Glob Change Biol 17:140-153

Fuentes MM, Pike DA, Dimatteo A, Wallace BP (2013) Resilience of marine turtle regional management units to climate change. Glob Change Biol 19:1399-1406

Fuentes MMPB, Bell I, Hagihara R, Hamann M and others (2015a) Improving in-water estimates of marine turtle abundance by adjusting aerial survey counts for perception and availability biases. J Exp Mar Biol Ecol 471: 77-83

Fuentes MMPB, Blackwood J, Jones B, Kim M and others (2015b) A decision framework for prioritizing multiple management actions for threatened marine megafauna. Ecol Appl 25:200-214

Fujioka E, Halpin PN (2014) Spatio-temporal assessments of biodiversity in the high seas. Endang Species Res 24: 181-190

Fujioka EJ, Kot CY, Wallace BP, Best BD and others (2014a) Data integration for conservation: leveraging multiple data types to advance ecological assessments and habitat modeling for marine megavertebrates using OBISSEAMAP. Ecol Inform 20:13-26

Fujioka E, Soldevilla MS, Read AJ, Halpin PN (2014b) Integration of passive acoustic monitoring data into OBISSEAMAP, a global biogeographic database, to advance spatially-explicit ecological assessments. Ecol Inform 21:59-73

Fujisaki I, Lamont MM (2016) The effects of large beach debris on nesting sea turtles. J Exp Mar Biol Ecol 482:33-37

Fukuoka T, Narazaki T, Sato K (2015) Summer-restricted migration of green turtles Chelonia mydas to a temperate habitat of the northwest Pacific Ocean. Endang Species Res 28:1-10

Fuller W, Godley B, Hodgson D, Reece SE, Witt M, Broderick A (2013) Importance of spatio-temporal data for predicting the effects of climate change on marine turtle sex ratios. Mar Ecol Prog Ser 488:267-274

Funk WC, McKay JK, Hohenlohe PA, Allendorf FW (2012) Harnessing genomics for delineating conservation units. Trends Ecol Evol 27:489-496

Gaos AR, Yañez IL (2012) Saving the eastern Pacific hawksbill from extinction: last chance or chance lost? In: JA Seminoff, BP Wallace (eds) Sea turtles of the eastern Pacific: advances in research and conservation. University of Arizona Press, Tucson, AZ, p 244-262

* Gaos AR, Abreu-Grobois FA, Alfaro-Shigueto J, Amorocho D and others (2010) Signs of hope in the eastern Pacific: international collaboration reveals encouraging status for a severely depleted population of hawksbill turtles Eretmochelys imbricata. Oryx 44:595-601

Gaos AR, Lewison RL, Liles MJ, Gadea V and others (2016) Hawksbill turtle terra incognita: conservation genetics of eastern Pacific rookeries. Ecol Evol 6:1251-1264

García-Cruz MA, Lampo M, Peñaloza CL, Kendall WL, Solé G, Rodríguez-Clark KM (2015) Population trends and survival of nesting green sea turtles Chelonia mydas on Aves Island, Venezuela. Endang Species Res 29:103-116

García-Fernández AJ, Gómez-Ramírez P, Martínez-López E, Hernández-García A and others (2009) Heavy metals in tissues from loggerhead turtles (Caretta caretta) from the southwestern Mediterranean (Spain). Ecotoxicol Environ Saf 72:557-563

García-Párraga D, Crespo-Picazo JL, Bernaldo de Quirós Y, Cervera V and others (2014) Decompression sickness ('the bends') in sea turtles. Dis Aquat Org 111:191-205
Garland KA, Carthy RR (2010) Changing taste preferences, market demands and traditions in Pearl Lagoon, Nicaragua: a community reliant on green turtles for income and nutrition. Conserv Soc 8:55-72

Gaspar P, Benson SR, Dutton PH, Réveillère A and others (2012) Oceanic dispersal of juvenile leatherback turtles: going beyond passive drift modeling. Mar Ecol Prog Ser 457:265-284

*Georges A, Limpus CJ, Stoutjesdijk R (1994) Hatchling sex in the marine turtle Caretta caretta is determined by proportion of development at a temperature, not daily duration of exposure. J Exp Zool 270:432-444

* Giardina E, Spinella A, Novelli G (2011) Past, present and future of forensic DNA typing. Nanomedicine 6:257-270

Gilman E, Huang HW (2016) Review of effects of pelagic longline hook and bait type on sea turtle catch rate, anatomical hooking position and at-vessel mortality rate. Rev Fish Biol Fish. doi:10.1007/s11160-016-9447-9

Gilman E, Zollett E, Beverly S, Nakano H and others (2006) Reducing sea turtle by-catch in pelagic longline fisheries. Fish Fish 7:2-23

* Gilman E, Kobayashi D, Swenarton T, Brothers N, Dalzell P, Kinan-Kelly I (2007) Reducing sea turtle interactions in the Hawaii-based longline swordfish fishery. Biol Conserv 139:19-28

* Gilman E, Gearhart J, Price B, Eckert S and others (2010) Mitigating sea turtle by-catch in coastal passive net fisheries. Fish Fish 11:57-88

Gilman E, Owens M, Kraft T (2014) Ecological risk assessment of the Marshall Islands longline tuna fishery. Mar Policy 44:239-255

Girard A, Dembe Louvinguila H, Breheret N, Monsinjon J and others (2014) Les engins et techniques de pêche utilisés dans la baie de Loango, République du Congo, et leurs incidences sur les prises accessoires. Cybium 38: $117-131$

* Girondot M (2010) Estimating density of animals during migratory waves: a new model applied to marine turtles at nesting sites. Endang Species Res 12:95-105

Girondot M, Garcia J (1999) Senescence and longevity in turtles: what telomeres tell us. In: Miaud DC, Guyetant R (eds) Proceedings of the $9^{\text {th }}$ Ordinary General Meeting of the Societas Europaea Herpetologica. Societa Europea Herpetologica, Le Bourget du Lac, p 133-137

*Girondot M, Kaska Y (2014) A model to predict the thermal reaction norm for the embryo growth rate from field data. J Therm Biol 45:96-102

Girondot M, Kaska Y (2015) Nest temperatures in a loggerhead-nesting beach in Turkey is more determined by sea surface temperature than air temperature. J Therm Biol 47:13-18

Girondot M, Rizzo A (2015) Bayesian framework to integrate traditional ecological knowledge into ecological modelling: a case study. J Ethnobiol 35:337-353

Gjertsen H, Squires D, Dutton PH, Eguchi T (2014) Costeffectiveness of alternative conservation strategies with application to the Pacific leatherback turtle. Conserv Biol 28:140-149

Goatley CHR, Hoey AS, Bellwood DR (2012) The role of turtles as coral reef macroherbivores. PLOS ONE 7:e39979

Godley BJ, Thomson DR, Furness RW (1999) Do heavy metal compounds pose a threat to marine turtles in the Mediterranean Sea? Mar Pollut Bull 38:497-502

Godley BJ, Blumenthal JM, Broderick AC, Coyne MS, God- 
frey MH, Hawkes LA, Witt MJ (2008) Satellite tracking of sea turtles: Where have we been and where do we go next? Endang Species Res 4:3-22

* Gómez-Picos P, Sifuentes-Romero I, Merchant-Larios H, Hernandez-Cornejo R, Diaz-Hernandez V, Garcia-Gasca A (2014) Expression of aromatase in the embryonic brain of the olive ridley sea turtle (Lepidochelys olivacea), and the effect of bisphenol-A in sexually differentiated embryos. Int J Dev Biol 58:733-741

*González Carman V, Acha EM, Maxwell SM, Albareda D, Campagna C, Mianzan H (2014a) Young green turtles, Chelonia mydas, exposed to plastic in a frontal area of the SW Atlantic. Mar Pollut Bull 78:56-62

* González Carman V, Botto F, Gaitan E, Albareda D, Campagna C, Mianzan H (2014b) A jellyfish diet for the herbivorous green turtle Chelonia mydas in the temperate SW Atlantic. Mar Biol 161:339-349

* González-Garza BI, Stow A, Felipe Sanchez-Teyer L, Zapata-Perez O (2015) Genetic variation, multiple paternity, and measures of reproductive success in the critically endangered hawksbill turtle (Eretmochelys imbricata). Ecol Evol 5:5758-5769

* Goodman Hall A, Avens L, McNeill JB, Wallace B, Goshe LR (2015) Inferring long-term foraging trends of individual juvenile loggerhead sea turtles using stable isotopes. Mar Ecol Prog Ser 537:265-276

* Gorham JC, Clark DR, Bresette MJ, Bagley DA and others (2014) Characterization of a subtropical hawksbill sea turtle (Eretmochelys imbricata) assemblage utilizing shallow water natural and artificial habitats in the Florida Keys. PLOS ONE 9:e114171

* Grayson JM, Hamann M, Marsh H, Ambar S (2010) Options for managing the sustainable use of green turtles: perceptions of Hammond Islanders in Torres Strait. Conserv Soc 8:73-83

* Gredzens C, Marsh H, Fuentes MM, Limpus CJ, Shimada T, Hamann M (2014) Satellite tracking of sympatric marine megafauna can inform the biological basis for species comanagement. PLOS ONE 9:e98944

* Grego JM, Hitchcock DB (2014) Limited-information modeling of loggerhead turtle population size. J Agric Biol Environ Stat 19:18-38

Griffin DB, Murphy SR, Frick MG, Broderick AC and others (2013) Foraging habitats and migration corridors utilized by a recovering subpopulation of adult female loggerhead sea turtles: implications for conservation. Mar Biol 160:3071-3086

Guilder J, Barca B, Arroyo-Arce S, Gramajo R, Salom-Pérez R (2015) Jaguars (Panthera onca) increase kill utilization rates and share prey in response to seasonal fluctuations in nesting green turtle (Chelonia mydas mydas) abundance in Tortuguero National Park, Costa Rica. Mamm Biol 80:65-72

Guirlet E, Das K, Girondot M (2008) Maternal transfer of trace elements in leatherback turtles (Dermochelys coriacea) of French Guiana. Aquat Toxicol 88:267-276

Guirlet E, Das K, Thomé JP, Girondot M (2010) Maternal transfer of chlorinated contaminants in the leatherback turtles, Dermochelys coriacea, nesting in French Guiana. Chemosphere 79:720-726

Halkyard B (2014) Exploiting green and hawksbill turtles in Western Australia: the commercial marine turtle fishery. In: Christensen J, Tull M (eds) Historical perspectives of fisheries exploitation in the Indo-Pacific. MARE Publication Series, Springer, Dordrecht, p 211-230
Hall MA, Roman M (2013) Bycatch and non-tuna catch in the tropical tuna purse seine fisheries of the world. FAO Fisheries and Aquaculture Tech Pap No. 568. FAO, Rome. www.fao.org/3/a-i2743e.pdf

*Halpern BS, Frazier M, Potapenko J, Casey KS and others (2015) Spatial and temporal changes in cumulative human impacts on the world's ocean. Nat Commun 6:7615

*Hamabata T, Kamezaki N, Hikida T (2014) Genetic structure of green turtle (Chelonia mydas) peripheral populations nesting in the northwestern Pacific rookeries: evidence for northern refugia and postglacial colonization. Mar Biol 161:495-507

*Hamabata T, Hikida T, Okamoto K, Watanabe S, Kamezaki $\mathrm{N}$ (2015) Ontogenetic habitat shifts of green turtles (Chelonia mydas) suggested by the size modality in foraging aggregations along the coasts of the western Japanese main islands. J Exp Mar Biol Ecol 463:181-188

*Hamann M, Godfrey MH, Seminoff JA, Arthur KE and others (2010) Global research priorities for sea turtles: informing management and conservation in the 21st century. Endang Species Res 11:245-269

* Hamann M, Grech A, Wolanskic E, Lambrechts J (2011) Modelling the fate of marine turtle hatchlings. Ecol Modell 222:1515-1521

* Hamilton RJ, Bird T, Gereniu C, Pita J and others (2015) Solomon Islands largest hawksbill turtle rookery shows signs of recovery after 150 years of excessive exploitation. PLOS ONE 10:e0121435

*Hammerschlag N, Broderick AC, Coker JW, Coyne MS and others (2015) Evaluating the landscape of fear between apex predatory sharks and mobile sea turtles across a large dynamic seascape. Ecology 96:2117-2126

*Hancock JM, Furtado S, Merino S, Godley BJ, Nuno A (in press) Exploring drivers and deterrents of illegal consumption and trade of marine turtle products in Cape Verde, and implications for conservation planning. Oryx, doi: 10.1017/S0030605316000107

* Hancock-Hanser BL, Frey A, Leslie MS, Dutton PH, Archer FI, Morin PA (2013) Targeted multiplex next-generation sequencing: advances in techniques of mitochondrial and nuclear DNA sequencing for population genomics. Mol Ecol Resour 13:254-268

*Hannan LB, Roth JD, Ehrhart LM, Weishampel JF (2007) Dune vegetation fertilization by nesting sea turtles. Ecology 88:1053-1058

*Hardy RF, Tucker AD, Foley AM, Schroeder BA, Giove RJ, Meylan AB (2014) Spatiotemporal occurrence of loggerhead turtles (Caretta caretta) on the West Florida Shelf and apparent overlap with a commercial fishery. Can J Fish Aquat Sci 71:1924-1933

Hargrove SK, Work TM, Brunson S, Foley AM, Balazs GH (2016) Proceedings of the 2015 international summit on fibropapillomatosis: global status, trends, and population impacts. US Dept Commerce, NOAA Tech Memo NOAA-TM-NMFS-PIFSC-54

*Harris HS, Benson SR, Gilardi KV, Poppenga RH, Work TM, Dutton PH, Mazet JAK (2011) Comparative health assessment of western Pacific leatherback turtles (Dermochelys coriacea) foraging off the coast of California, 2005-2007. J Wildl Dis 47:321-337

* Harris LR, Nel R, Oosthuizenb H, Meÿer M and others (2015) Paper-efficientmulti-species conservation and management are not always field-effective: the status and future of Western Indian Ocean leatherbacks. Biol Conserv 191: 383-390 
Hart KM, Hyrenbach KD (2009) Satellite telemetry of marine megavertebrates: the coming of age of an experimental science. Endang Species Res 10:9-20

*Hart KM, Lamont MM, Fujisaki I, Tucker AD, Carthy RR (2012) Common coastal foraging areas for loggerheads in the Gulf of Mexico: opportunities for marine conservation. Biol Conserv 145:185-194

* Hart KM, Zawada DG, Fujisaki I, Lidz BH (2013) Habitat use of breeding green turtles Chelonia mydas tagged in Dry Tortugas National Park: making use of local and regional MPAs. Biol Conserv 161:142-154

* Hart KM, Lamont MM, Sartain AR, Fujisaki I (2014) Migration, foraging, and residency patterns for northern gulf loggerheads: implications of local threats and international movements. PLOS ONE 9:e103453

Hart CE, Blanco GS, Coyne MS, Delgado-Trejo C and others (2015) Multinational tagging efforts illustrate regional scale of distribution and threats for East Pacific green turtles (Chelonia mydas agassizii). PLOS ONE 10:e0116225

Hatase H, Sudo R, Watanabe KK, Kasugai T, Saito T, Okamoto H, Tsukamoto K (2008) Shorter telomere length with age in the loggerhead turtle: a new hope for live sea turtle age estimation. Genes Genet Syst 83:423-426

Hatase H, Kazuyoshi O, Katsumi T (2013) A mechanism that maintains alternative life histories in a loggerhead sea turtle population. Ecology 94:2583-2594

* Hawkes LA, Broderick AC, Coyne MS, Godfrey MH and others (2006) Phenotypically linked dichotomy in sea turtle foraging requires multiple conservation approaches. Curr Biol 16:990-995

Hawkes LA, Broderick AC, Godfrey MH, Godley BJ (2007) Investigating the potential impacts of climate change on a marine turtle population. Glob Change Biol 13:923-932

Hawkes LA, McGowan A, Broderick AC, Gore S and others (2014) High rates of growth recorded for hawksbill sea turtles in Anegada, British Virgin Islands. Ecol Evol 4: $1255-1266$

Hays GC, Marsh R (1997) Estimating the age of juvenile loggerhead sea turtles in the North Atlantic. Can J Zool 75 : 40-46

Hays GC, Fossette S, Katselidis KA, Mariani P, Schofield G (2010a) Ontogenetic development of migration: Lagrangian drift trajectories suggest a new paradigm for sea turtles. J R Soc Interface 7:1319-1327

Hays GC, Fossette S, Katselidis KA, Schofield G, Gravenor MB (2010b) Breeding periodicity for male sea turtles, operational sex ratios, and implications in the face of climate change. Conserv Biol 24:1636-1643

Hays GC, Mazaris AD, Schofield G (2014a) Different male vs. female breeding periodicity helps mitigate offspring sex ratio skews in sea turtles. Front Mar Sci 1:43

Hays GC, Mortimer JA, Ierodiaconou D, Esteban N (2014b) Use of long-distance migration patterns of an endangered species to inform conservation planning for the world's largest marine protected aea. Conserv Biol 28: 1636-1644

Hays GC, Ferreira LC, Sequeira AMM, Meekan MG and others (2016) Key questions in marine megafauna movement ecology. Trends Ecol Evol 31:463-475

*Hedley J, Roelfsema C, Chollett I, Harborne A and others (2016) Remote sensing of coral reefs for monitoring and management: a review. Remote Sens 8:118

Heithaus MR, Alcoverro T, Arthur R, Burkholder DA and others (2014) Seagrasses in the age of sea turtle conservation and shark overfishing. Front Mar Sci 1:28
Heppell SS, Snover ML, Crowder LB (2003) Sea turtle population ecology. In: Lutz PL, Musick JA (eds) The biology of sea turtles. CRC Press, Boca Raton, FL, p 275-306

Hill BA, Stewart KM, Rawlins-Vaughan G, Illanes O and others (2014) Clinical challenge. J Zoo Wildl Med 45: 200-204

*Hill W, Byrne J, Pickering C (2015a) The 'hollow-middle': why positive community perceptions do not translate into pro-conservation behaviour in El Vizcaíno Biosphere Reserve, Mexico. Int J Biodivers Sci Ecosyst Serv Manage 11:168-183

*Hill JE, Paladino FV, Spotila JR, Tomillo PS (2015b) Shading and watering as a tool to mitigate the impacts of climate change in sea turtle nests. PLOS ONE 10:e0129528

* Hirama S, Ehrhart LM, Rea LD, Kiltie RA (2014) Relating fibropapilloma tumor severity to blood parameters in green turtles Chelonia mydas. Dis Aquat Org 111:61-68

* Hoarau L, Ainley L, Jean C, Ciccione S (2014) Ingestion and defecation of marine debris by loggerhead sea turtles, Caretta caretta, from by-catches in the South-West Indian Ocean. Mar Pollut Bull 84:90-96

* Horne CR, Fuller WJ, Godley BJ, Rhodes KA, Snape R, Stokes KL, Broderick AC (2014) The effect of thermal variance on the phenotype of marine turtle offspring. Physiol Biochem Zool 87:796-804

*Howard R, Bell I, Pike DA (2014) Thermal tolerances of sea turtle embryos: current understanding and future directions. Endang Species Res 26:75-86

*Howard R, Bell I, Pike DA (2015) Tropical flatback turtle (Natator depressus) embryos are resilient to the heat of climate change. J Exp Biol 218:3330-3335

*Howell E, Kobayashi D, Parker D, Balazs G (2008) TurtleWatch: a tool to aid in the bycatch reduction of loggerhead turtles Caretta caretta in the Hawaii-based pelagic longline fishery. Endang Species Res 5:267-278

*Howell EA, Hoover A, Benson SR, Bailey H, Plovina JJ, Seminoff JA, Dutton PH (2015) Enhancing the TurtleWatch product for leatherback sea turtles, a dynamic habitat model for ecosystem-based management. Fish Oceanogr 24:57-68

Huang HW (2015a) Conservation hotspots for the turtles on the high seas of the Atlantic Ocean. PLOS ONE 10: e0133614

Huang HW (2015b) Incidental catch of seabirds and sea turtles by Taiwanese longline fleets in the Pacific Ocean. Fish Res 170:179-189

* Hulin V, Delmas V, Girondot M, Godfrey MH, Guillon JM (2009) Temperature-dependent sex determination and global change: Are some species at greater risk? Oecologia 160:493-506

*Humber F, Godley BJ, Ramahery V, Broderick AC (2011) Using community members to assess artisanal fisheries: the marine turtle fishery in Madagascar. Anim Conserv 14:175-185

*Humber F, Godley BJ, Broderick AC (2014) So excellent a fishe: a global overview of legal marine turtle fisheries. Divers Distrib 20:579-590

*Humber F, Andriamahefazafy M, Godley BJ, Broderick AC (2015) Endangered, essential and exploited: how extant laws are not enough to protect marine megafauna in Madagascar. Mar Policy 60:70-83

Ikonomopoulou MP, Olszowy H, Limpus C, Francis R, Whittier J (2011) Trace element concentrations in nesting flatback turtles (Natator depressus) from Curtis Island, Queensland, Australia. Mar Environ Res 71:10-16 
Innis CJ, Merigo C, Cavin JM, Hunt K, Dodge KL, Lutcavage $M$ (2014) Serial assessment of the physiological status of leatherback turtles (Dermochelys coriacea) during direct capture events in the northwestern Atlantic Ocean: comparison of post-capture and pre-release data. Conserv Physiol 2:cou048

Isler CT, Altug M, Cantekin Z, Ozsoy SY, Yurtal Z, Deveci MZY (2014) Evaluation of the eye diseases seen in loggerhead sea turtle (Caretta caretta). Rev Med Vet (Toulouse) 165:258-262

Jackson AL, Broderick AC, Fuller WJ, Glen F, Ruxton GD, Godley BJ (2008) Sampling design and its effect on population monitoring: How much monitoring do turtles really need? Biol Conserv 141:2932-2941

Jackson MV, Kennett R, Bayliss P, Warren R and others (2015) Developing collaborative marine turtle monitoring in the Kimberley region of northern Australia. Ecol Manage Restor 16:163-176

Jeffers VF, Godley BJ (2016) Satellite tracking in sea turtles: How do we find our way to the conservation dividends? Biol Conserv 199:172-184

* Jensen MP, Limpus CJ, Whiting SD, Guinea M and others (2013) Defining olive ridley turtle Lepidochelys olivacea management units in Australia and assessing the potential impact of mortality in ghost nets. Endang Species Res 21:241-253

Jensen MP, Bell I, Limpus CJ, Hamann M and others (2016) Spatial and temporal genetic variation among size classes of green turtles (Chelonia mydas) provides information on oceanic dispersal and population dynamics. Mar Ecol Prog Ser 543:241-256

* Jin L, Escher BI, Limpus CJ, Gaus C (2015) Coupling passive sampling with in vitro bioassays and chemical analysis to understand combined effects of bioaccumulative chemicals in blood of marine turtles. Chemosphere 138: 292-299

Jones TT, Seminoff JA (2013) Feeding biology: advances from field-based observations, physiological studies, and nolecular techniques. In: Wyneken J, Lohmann KJ, Musick JA (eds) The biology of sea turtles, Vol III. CRC Press, Boca Raton, FL, p 211-248

Jones K, Ariel E, Burgess G, Read M (2016) A review of fibropapillomatosis in green turtles (Chelonia mydas). Vet J 212:48-57

Jordão JC, Vigliar Bondioli AC, Guebert FM, de Thoisy B, de Almeida Toledo LF (2015) Green turtle (Chelonia mydas) genetic diversity at Paranagua Estuarine Complex feeding grounds in Brazil. Genet Mol Biol 38:346-352

Joseph J, Kuen CY, Palaniappan PM, Chark LH (2014) Genetic investigation of green turtles (Chelonia mydas) harvested from a foraging ground at Mantanani, Sabah, Malaysia. Herpetol Conserv Biol 9:516-523

Jourdan J, Fuentes MMPB (2015) Effectiveness of strategies at reducing sand temperature to mitigate potential impacts from changes in environmental temperature on sea turtle reproductive output. Mitig Adapt Strategies Glob Change 20:121-133

Jribi I, Bradai MN (2014) Sex ratio estimations of loggerhead sea turtle hatchlings at Kuriat islands, Tunisia: can minor nesting sites contribute to compensate globally femalebiased sex ratio? Sci World J 2014:419410

Kamel SJ, Mrosovsky N (2005) Repeatability of nesting preferences in the hawksbill sea turtle, Eretmochelys imbricata, and their fitness consequences. Anim Behav 70 : 819-828
Kamrowski RL, Limpus C, Moloney J, Hamann M (2012) Coastal light pollution and marine turtles: assessing the magnitude of the problem. Endang Species Res 19:85-98

Kamrowski RL, Limpus C, Jones R, Anderson S, Hamann M (2014a) Temporal changes in artificial light exposure of marine turtle nesting areas. Glob Change Biol 20: 2437-2449

Kamrowski RL, Sutton SG, Renae CT, Hamann M (2014b) Potential applicability of persuasive communication to light-glow reduction efforts: a case study of marine turtle conservation. Environ Manage 54:583-595

Kamrowski RL, Limpus C, Pendoley K, Hamann M (2014c) Influence of industrial light pollution on the sea-finding behaviour of flatback turtle hatchlings. Wildl Res 41: 421-434

Kane Y, Kerbai S, Kadja M, Wyers M (2012) La fibropapillomatose des tortues marines: état des lieux et perspectives. Revue Africaine de Santé et de Productions Animales 10:3-10

Katselidis KA, Schofield G, Stamou G, Dimopoulos P, Pantis JD (2014) Employing sea-level rise scenarios to strategically select sea turtle nesting habitat important for longterm management at a temperate breeding area. J Exp Mar Biol Ecol 450:47-54

Kawazu I, Kino M, Maeda K (2015a) Relationship between the water temperature experienced by captive loggerhead turtles (Caretta caretta) and eggshell formation. Herpetol Rev 46:364-368

Kawazu I, Kino M, Maeda K, Teruya H (2015b) Age and body size of captive hawksbill turtles at the onset of follicular development. Zoo Biol 34:178-182

Keller JM, Balazs GH, Nilsen F, Rice M, Work TM, Jensen BA (2014) Investigating the potential role of persistent organic pollutants in Hawaiian green sea turtle fibropapillomatosis. Environ Sci Technol 48:7807-7816

Kelly TR, McNeill JB, Avens L, Hall AG and others (2015) Clinical pathology reference intervals for an in-water population of juvenile loggerhead sea turtles (Caretta caretta) in core sound, North Carolina, USA. PLOS ONE 10:e0115739.

Kilic C, Candan O (2014) Hatchling sex ratio, body weight and nest parameters for Chelonia mydas nesting on Sugozu beaches (Turkey). Anim Biodivers Conserv 37:177-182

*Kobayashi DR, Farman R, Polovina JJ, Parker DM, Rice M (2014) 'Going with the flow' or not: evidence of positive rheotaxis in oceanic juvenile loggerhead turtles (Caretta caretta) in the South Pacific Ocean using satellite tags and ocean circulation data. PLOS ONE 9:e103701

Kobayashi S, Saito Y, Osawa A, Katsumata E and others (2015) Embryonic sex steroid hormones accumulate in the eggshell of loggerhead sea turtle (Caretta caretta). Gen Comp Endocrinol 224:11-17

Komoroske LM, Lewison RL, Seminoff JA, Deheyn DD, Dutton PH (2011) Pollutants and the health of green sea turtles resident to an urbanized estuary in San Diego, CA. Chemosphere 84:544-552

Kumar HS, Panditrao S, Baliarsingh SK, Mohanty P, Mahendra RS, Lotliker AA, Kumar TS (2014) Consequence of cyclonic storm Phailin on coastal morphology of Rushikulya estuary: an arribada site of vulnerable olive ridley sea turtles along the east coast of India. Curr Sci 107: 28-30

Kuo M (2015) How might contact with nature promote human health? Promising mechanisms and a possible central pathway. Front Psychol 6:1093 
Kvamsdal SF, Stohs SM (2014) Estimating endangered species risk with the Kalman Filter. Am J Agric Econ 96: 458-468

*abrada-Martagón V, Zenteno-Savin T, Mangel M (2014) Linking physiological approaches to marine vertebrate conservation: using sex steroid hormone determinations in demographic assessments. Conserv Physiol 2: $\cot 035$

Lacey EA, Collado-Vides L, Fourqurean JW (2014) Morphological and physiological responses of seagrasses (Alismatales) to grazers (Testudines: Cheloniidae) and the role of these responses as grazing patch abandonment cues. Rev Biol Trop 62:1535-1548

* Lagueux CJ, Campbell CL, Strindberg S (2014) Artisanal green turtle, Chelonia mydas, fishery of Caribbean Nicaragua. I. Catch rates and trends, 1991-2011. PLOS ONE 9:e94667

Lal A, Arthur R, Marbà N, Lill AWT, Alcoverro T (2010) Implications of conserving an ecosystem modifier: increasing green turtle (Chelonia mydas) densities substantially alters seagrass meadows. Biol Conserv 143: 2730-2738

Kaloë JO, Cozens J, Renom B, Taxonera A, Hays GC (2014) Effects of rising temperature on the viability of an important sea turtle rookery. Nat Clim Change 4:513-518

Laloë JO, Esteban N, Berkel J, Hays GC (2016) Sand temperatures for nesting sea turtles in the Caribbean: implications for hatchling sex ratios in the face of climate change. J Exp Mar Biol Ecol 474:92-99

Lam JCW, Tanabe S, Chan SKF, Lam MHW, Martin M, Lam PKS (2006) Levels of trace elements in green turtle eggs collected from Hong Kong: evidence of risks due to selenium and nickel. Environ Pollut 144:790-801

Lamarre-DeJesus AS, Griffin CR (2015) Habanero pepper powder as a potential deterrent to nest predation of turtle nests: a response to Burke et al. (Chelonian Conservation and Biology, 14(2):201-203, 2015). Chelonian Conserv Biol 14:203-204

Lamont MM, Fujisaki I (2014) Effects of ocean temperature on nesting phenology and fecundity of the loggerhead sea turtle (Caretta caretta). J Herpetol 48:98-102

Lamont MM, Houser C (2014) Spatial distribution of loggerhead turtle (Caretta caretta) emergences along a highly dynamic beach in the northern Gulf of Mexico. J Exp Mar Biol Ecol 453:98-107

Lamont MM, Fujisaki I, Carthy RR (2014) Estimates of vital rates for a declining loggerhead turtle (Caretta caretta) subpopulation: implications for management. Mar Biol 161:2659-2668

Lamont MM, Putman NF, Fujisaki I, Hart K (2015) Spatial requirements of different life-stages of the loggerhead turtle (Caretta caretta) from a distinct population segment in the northern Gulf of Mexico. Herpetol Conserv Biol 10:26-43

Lasala JA, Harrison JS, Williams KL, Rostal DC (2013) Strong male-biased operational sex ratio in a breeding population of loggerhead turtles (Caretta caretta) inferred by paternal genotype reconstruction analysis. Ecol Evol 3: 4736-4747

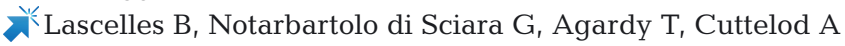
and others (2014) Migratory marine species: their status, threats and conservation management needs. Aquat Conserv 24:111-127

Lauriano G, Panigada S, Casale P, Pierantonio N, Donovan GP (2011) Aerial survey abundance estimates of the log- gerhead sea turtle Caretta caretta in the Pelagos Santuary, northwestern Mediterranean Sea. Mar Ecol Prog Ser 437:291-302

Lazar B, Maslov L, Romani S, Gra an R, Krauthacker B, Holcer D, Tvrtkovi N (2011) Accumulation of organochlorine contaminants in loggerhead sea turtles, Caretta caretta, from the eastern Adriatic Sea. Chemosphere 82:121-129

LeBlanc AM, Rostal DC, Drake KK, Williams KL, Frick MG, Robinette J, Barnard-Keinath DE (2014) The influence of maternal size on the eggs and hatchlings of loggerhead sea turtles. Southeast Nat 13:587-599

Levy Y, Perry N, Tchernov D, Rilov G (2014) Use of an intensive care tank for treatment of sea turtles. Herpetol Rev 45:632-635

* Levy Y, Frid O, Weinberger A, Sade R and others (2015) A small fishery with a high impact on sea turtle populations in the eastern Mediterranean. Zool Middle East 61: 300-317

* Lewbart GA, Hirschfeld M, Denkinger J, Vasco K and others (2014) Blood gases, biochemistry, and hematology of Galapagos green turtles (Chelonia mydas). PLOS ONE 9: e96487

K Lewison R, Oro D, Godley BJ, Underhill L and others (2012) Research priorities for seabirds: improving conservation and management in the 21st century. Endang Species Res 17:93-121

KLewison RL, Crowder LB, Wallace BP, Moore J and others (2014) Global patterns of marine mammal, seabird, and sea turtle bycatch reveal taxa-specific and cumulative megafauna hotspots. Proc Natl Acad Sci USA 111: 5271-5276

Kewison R, Hobday AJ, Maxwell S, Hazen E and others (2015) Dynamic ocean management: identifying the critical ingredients of dynamic approaches to ocean resource management. Bioscience 65:486-498

* Ley-Quiñónez C, Zavala-Norzagaray AA, Espinosa-Carreon TL, Peckham H, Marquez-Herrera C, Campos-Villegas L, Aguirre AA (2011) Baseline heavy metals and metalloid values in blood of loggerhead turtles (Caretta caretta) from Baja California Sur, Mexico. Mar Pollut Bull 62: 1979-1983

Li TH, Chang CC, Cheng IJ, Lin SC (2015) Development of a summarized health index (SHI) for use in predicting survival in sea turtles. PLOS ONE 10:e0120796

Liles MJ, Peterson MJ, Lincoln YS, Seminoff JA, Gaos AR, Peterson TR (2014) Connecting international priorities with human wellbeing in low-income regions: lessons from hawksbill turtle conservation in El Salvador. Local Environ 11:1383-1404

Liles MJ, Peterson MJ, Seminoff JA, Altamirano E and others (2015) One size does not fit all: importance of adjusting conservation practices for endangered hawksbill turtles to address local nesting habitat needs in the eastern Pacific Ocean. Biol Conserv 184:405-413

KLimpus CJ, Miller JD, Parmenter CJ, Reimer D, McLachland N, Webb R (1992) Migration of green (Chelonia mydas) and loggerhead (Caretta caretta) turtles to and from eastern Australian rookeries. Wildl Res 19:347-358

KLolavar A, Wyneken J (2015) Effect of rainfall on loggerhead turtle nest temperatures, sand temperatures and hatchling sex. Endang Species Res 28:235-247

Lopez J (2015) Biodiversity on the brink: the role of 'assisted migration' in managing endangered species threatened with rising seas. Harvard Environ Law Rev 39:157-190 
Lopez GG, Sali EDC, Lara PH, Tognin F, Marcovaldi MA, Serafini TZ (2015) Coastal development at sea turtles nesting ground: efforts to establish a tool for supporting conservation and coastal management in northeastern Brazil. Ocean Coast Manage 116:270-276

López-Castro MC, Bjorndal KA, Kamenov GD, Zenil-Ferguson R, Bolten AB (2013) Sea turtle population structure and connections between oceanic and neritic foraging areas in the Atlantic revealed through trace elements. Mar Ecol Prog Ser 490:233-246

López-Castro MC, Bjorndal KA, Bolten AB (2014a) Evaluation of scute thickness to infer life history records in the carapace of green and loggerhead turtles. Endang Species Res 24:191-196

López-Castro MC, Bjorndal KA, Kamenov GD, Bolten AB (2014b) Identifying oceanic foraging grounds of sea turtles in the Atlantic using lead isotopes. Mar Biol 161: 2269-2278

*ópez-Mendilaharsu M, Vélez-Rubio GM, Lezama C, Aisenberg A and others (2016) Demographic and tumour prevalence data for juvenile green turtles at the CoastalMarine Protected Area of Cerro Verde, Uruguay. Mar Biol Res 12:541-550

Luschi P, Casale P (2014) Movement patterns of marine turtles in the Mediterranean Sea: a review. Ital J Zool 81: 478-495

* Machado Guimarães S, Gitirana HM, Wanderley AV, Monteiro-Neto C, Lobo-Hajdu G (2013) Evidence of regression of fibropapillomas in juvenile green turtles Chelonia mydas caught in Niterói, southeast Brazil. Dis Aquat Org 102:243-247

Macrae I, Whiting SD (2014) Positive conservation outcome from religious teachings: changes to subsistence turtle harvest practices at Cocos (Keeling) Islands, Indian Ocean. Raffles Bull Zool Suppl 30:162-167

Madden D, Ballestero J, Calvo C, Carlson R, Christians E, Madden E (2008) Sea turtle nesting as a process influencing a sandy beach ecosystem. Biotropica 40:758-765

Madrigal-Ballestero R, Schlüter A, Lopez MC (2013) What makes them follow the rules? Empirical evidence from turtle egg harvesters in Costa Rica. Mar Policy 37:270-277

Maffucci F, Corrado R, Palatella L, Borra M and others (2016) Seasonal heterogeneity of ocean warming: a mortality sink for ectotherm colonizers. Sci Rep 6:23983

Mansfield KL, Wyneken J, Porter WP, Luo J (2014) First satellite tracks of neonate sea turtles redefine the 'lost years' oceanic niche. Proc R Soc B 281:20133039

Marcovaldi MA, Chaloupka M (2007) Conservation status of the loggerhead sea turtle in Brazil: an encouraging outlook. Endang Species Res 3:133-143

Marcovaldi MAG, Thomé JCA (1999) Reducing threats to turtles. In: Eckert KL, Bjorndal KA, Abreu-Grobois FA, Donnelly M (eds) Research and management techniques for the conservation of sea turtles. IUCN/SSC Marine Turtle Specialist Group Publication No. 4. IUCN, Washington, DC, p 165-168

Marcovaldi MA, López-Mendilaharsu M, Santos AS, Gustave GL and others (2016) Identification of loggerhead male producing beaches in the south Atlantic: implications for conservation. J Exp Mar Biol Ecol 477:14-22

Margaritoulis D, Touliatou S (2011) Mediterranean monk seals present an ongoing threat for loggerhead sea turtles in Zakynthos. Mar Turtle Newsl 131:18-23

Martin SL, Stohs SM, Moore JE (2015a) Bayesian inference and assessment for rare-event bycatch in marine fish- eries: a drift gillnet fishery case study. Ecol Appl 25: 416-429

Martin CS, Tolley MJ, Farmer E, Mcowena CJ and others (2015b) A global map to aid the identification and screening of critical habitat for marine industries. Mar Policy 53: 45-53

Mathenge SM, Mwasi BN, Mwasi SM (2012) Effects of anthropogenic activities on sea turtle nesting beaches along the Mombasa-Kilifi shoreline, Kenya. Mar Turtle Newsl 135:14-18

Matsuzawa Y, Kamezaki N, Ishihara T, Omuta K and others (2016) Fine scale genetic population structure of loggerhead turtles in the Northwest Pacific. Endang Species Res 30:83-93

Maufroy A, Chassot E, Joo R, Kaplan DM (2015) Large-scale examination of spatio-temporal patterns of drifting fish aggregating devices (dFADs) from tropical tuna fisheries of the Indian and Atlantic Oceans. PLOS ONE 10:e0128023

Maulany RI, Booth DT, Baxter GS (2012) Emergence success and sex ratio of natural and relocated nests of olive ridley turtles from Alas Purwo National Park, East Java, Indonesia. Copeia 2012:738-747

Maxwell SM, Ban NC, Morgan LE (2014) Pragmatic approaches for effective management of pelagic marine protected areas. Endang Species Res 26:59-74

* Maxwell SM, Hazen EL, Lewison RL, Dunn DC and others (2015) Dynamic ocean management: defining and conceptualizing real-time management of the ocean. Mar Policy 58:42-50

* Mazaris AD, Almpanidou V, Wallace BP, Pantis JD, Schofield G (2014) A global gap analysis of sea turtle protection coverage. Biol Conserv 173:17-23

* Mazaris AD, Vokou D, Almpanidou V, Türkozan O, Sgardelis SP (2015) Low conservatism of the climatic niche of sea turtles and implications for predicting future distributions. Ecosphere 6:art169

McCrink-Goode M (2014) Pollution: a global threat. Environ Int 68:162-170

*McDonald RI, Fielding KS, Louis WR (2014) Conflicting social norms and community conservation compliance. J Nat Conserv 22:212-216

* Mcelroy ML, Dodd MG, Castleberry SB (2015) Effects of common loggerhead sea turtle nest management methods on hatching and emergence success at Sapelo Island, Georgia, USA. Chelonian Conserv Biol 14:49-55

*McFadden KW, Gomez A, Sterling EJ, Naro-Maciel E (2014) Potential impacts of historical disturbance on green turtle health in the unique \& protected marine ecosystem of Palmyra Atoll (Central Pacific). Mar Pollut Bull 89:160-167

*Mestre F, Braganca MP, Nunes A, dos Santos ME (2014) Satellite tracking of sea turtles released after prolonged captivity periods. Mar Biol Res 10:996-1006

*Metcalfe K, Agamboue PD, Augowet E, Boussamba F and others (2015) Going the extra mile: ground-based monitoring of olive ridley turtles reveals Gabon hosts the largest rookery in the Atlantic. Biol Conserv 190:14-22

Meylan PA, Meylan AB, Gray JA (2011) The ecology and migrations of sea turtles 8. Tests of the developmental habitat hypothesis. Bull Am Mus Nat Hist 357:1-70

Meylan A, Arenas A, Zurita JC, Harrison E, Gray J, Meylan $P$ (2014) Turtles tagged in developmental habitat in Bermuda nest in Mexico and Costa Rica. Mar Turtle Newsl 141:15-17

Miller J, Limpus C, Godfrey MH (2003) Nest site selection, oviposition, eggs, development, hatching, and emer- 
gence of loggerhead sea turtles. In: Bolten A, Witherington B (eds) Loggerhead sea turtles. Smithsonian Institution Press, Washington, DC, p 125-143

* Molina Hernández AL, van Tussenbroek BI (2014) Patch dynamics and species shifts in seagrass communities under moderate and high grazing pressure by green sea turtles. Mar Ecol Prog Ser 517:143-157

Monezi TA, Mehnert DU, de Moura EM, Muller NM and others (2016) Chelonid herpesvirus 5 in secretions and tumor tissues from green turtles (Chelonia mydas) from Southeastern Brazil: a ten-year study. Vet Microbiol 186: 150-156

Montilla AJ, Prieto-Torres D, Hernandez JL, Alvarado MC (2014) Hematological survey of sea turtles Eretmochelys imbricata and Caretta caretta presents in the Alta Guajira, Gulf of Venezuela. Rev Cient Vet 24:363-371

* Monzón-Argüello C, Dell'amico F, Morinière P, Marco A and others (2012) Lost at sea: genetic, oceanographic and meteorological evidence for storm-forced dispersal. J R Soc Interface 9:1725-1732

Moore JE, Cox TM, Lewison RL, Read AJ and others (2010) An interview-based approach to assess marine mammal and sea turtle captures in artisanal fisheries. Biol Conserv 143:795-805

Morales Mérida A, Ruiz A, Navarro E, Sifuentes-Romero I, Abreu-Grobois FA, Girondot M (2015) Contrasting incubation data for Lepidochelys olivacea highlight the need for more experimentation and detailed reporting. Mar Turtle Newsl 145:15-19

Mortimer JA (1984) Marine turtles in the Republic of Seychelles: status and Management. IUCN Conservation Library, Gland

Mortimer JA (1990) The influence of beach sand characteristics on the nesting behavior and clutch survival of green turtles (Chelonia mydas). Copeia 1990:802-817

Mortimer JA (1995) Headstarting as a management tool. In: Bjorndal KA (ed) Biology and conservation of sea turtles. Smithsonian Instituton Press, Washington, DC, p 613-615

Mortimer JA, Carr A (1987) Reproduction and migrations of the Ascension Island green turtle (Chelonia mydas). Copeia 1987:103-113

Mortimer JA, von Brandis RG, Liljevik A, Chapman R, Collie $\mathrm{J}$ (2011) Fall and rise of nesting green turtles (Chelonia mydas) at Aldabra Atoll, Seychelles: positive response to four decades of protection (1968-2008). Chelonian Conserv Biol 10:165-176

Mrosovsky N, Dutton PH, Whitmore CP (1984) Sex ratios of two species of sea turtle nesting in Suriname. Can J Zool 62:2227-2239

Muñoz SV, Arauz R (2015) Conservation and reproductive activity of olive ridley sea turtle (Lepidochelys olivacea) in solitary nesting beach Punta Banco, South Pacific of Costa Rica: management recommendations from sixteen years of monitoring. Rev Biol Trop 63:383-394

* Muñoz FA, Franco-Noguez SY, Gonzalez-Ballesteros E, Negrete-Philippe AC, Flores-Romo L (2014) Characterisation of the green turtle's leukocyte subpopulations by flow cytometry and evaluation of their phagocytic activity. Vet Res Commun 38:123-128

Murray KT (2015) The importance of location and operational fishing factors in estimating and reducing loggerhead turtle (Caretta caretta) interactions in US bottom trawl gear. Fish Res 172:440-451

Narazaki T, Sato K, Abernathy KJ, Marshall GJ, Miyazaki N (2013) Loggerhead turtles (Caretta caretta) use vision to forage on gelatinous prey in mid-water. PLOS ONE 8: e66043

Narazaki T, Sato K, Miyazaki N (2015) Summer migration to temperate foraging habitats and active winter diving of juvenile loggerhead turtles Caretta caretta in the western North Pacific. Mar Biol 162:1251-1263

*Nardini G, Florio D, Di Girolamo N, Gustinelli A and others (2014) Disseminated mycobacteriosis in a stranded loggerhead sea turtle (Caretta caretta). J Zoo Wildl Med 45: 357-360

Naro-Maciel E, Gaughran SJ, Putman NF, Amato G and others (2014a) Predicting connectivity of green turtles at Palmyra Atoll, central Pacific: a focus on mtDNA and dispersal modelling. J R Soc Interface 11:20130888

*Naro-Maciel E, Reid BN, Alter SE, Amato G and others (2014b) From refugia to rookeries: phylogeography of Atlantic green turtles. J Exp Mar Biol Ecol 461:306-316

Naro-Maciel E, Hart KM, Cruciata R, Putman NF (2016) DNA and dispersal models highlight connectivity in a migratory marine megavertebrate. Ecography, doi:10.1111/ ecog. 02056

National Research Council (Committee on the Review of Sea Turtle Population Assessment Methods) (2010) Assessment of sea-turtle status and trends: integrating demography and abundance. National Academy Press, Washington, DC

Neeman N, Harrison E, Wehrmann IS, Bolanos F (2015a) Nest site selection by individual leatherback turtles (Dermochelys coriacea, Testudines: Dermochelyidae). Rev Biol Trop 63:491-500

* Neeman N, Robinson NJ, Paladino FV, Spotila JR, O'Connor MP (2015b) Phenology shifts in leatherback turtles (Dermochelys coriacea) due to changes in sea surface temperature. J Exp Mar Biol Ecol 462:113-120

*Neeman N, Spotila JR, O'Connor MP (2015c) A simple, physiologically-based model of sea turtle remigration intervals and nesting population dynamics: effects of temperature. J Theor Biol 380:516-523

Nelms SE, Piniak WED, Weir CR, Godley BJ (2016a) Seismic surveys and marine turtles: an underestimated global threat. Biol Conserv 193:49-65

Nelms SE, Duncan EM, Broderick AC, Galloway TS and others (2016b) Plastic and marine turtles: a review and call for research. ICES J Mar Sci 73:165-181

*Ng CK, Dutton PH, Chan SK, Cheung K, Qiu J, Sun Y (2014) Characterization and conservation concerns of green turtles (Chelonia mydas) nesting in Hong Kong, China. Pac Sci 68:231-243

Nifong JC, Frick MG, Eastman SF (2011) Putative predation and scavenging of two sea turtle species by the American alligator, Alligator mississippiensis, in coastal southeastern United States. Herpetol Rev 42:511-513

Nijman V (2015) Decades-long open trade in protected marine turtles along Java's south coast. Mar Turtle Newsl 144:10-13

Nilsen FM, Parrott BB, Bowden JA, Kassim BL, Somerville SE, Bryan TA, Long SE (2016) Global DNA methylation loss associated with mercury contamination and aging in the American alligator (Alligator mississippiensis). Sci Total Environ 545-546:389-397

Nishizawa H, Narazaki T, Fukuoka T, Sato K, Hamabata T, Kinoshita M, Arai N (2014a) Genetic composition of loggerhead turtle feeding aggregations: migration patterns in the North Pacific. Endang Species Res 24: 85-93 
Nishizawa H, Narazaki T, Fukuoka T, Sato K, Hamabata T, Kinoshita M, Arai N (2014b) Juvenile green turtles on the northern edge of their range: mtDNA evidence of longdistance westward dispersals in the northern Pacific Ocean. Endang Species Res 24:171-179

Nordmoe ED, Sieg AE, Sotherland PR, Spotila JR, Paladino FV, Reina RD (2004) Nest site fidelity of leatherback turtles at Playa Grande, Costa Rica. Anim Behav 68: 387-394

Norton TM, Cox S, Nelson SE Jr, Kaylor M, Thomas R, Hupp A, Sladky KK (2015) Pharmacokinetics of tramadol and O-desmethyltramadol in loggerhead sea turtles (Caretta caretta). J Zoo Wildl Med 46:262-265

* Orós J, González-Diaz OM, Monagas P (2009) High levels of polychlorinated biphenyls in tissues of Atlantic turtles stranded in the Canary Islands, Spain. Chemosphere 74: 473-478.

Orós J, Monagas P, Calabuig P, Luzardo O, Camacho M (2013) Pansteatitis associated with high levels of polychlorinated biphenyls in a wild loggerhead sea turtle Caretta caretta. Dis Aquat Org 102:237-242

* Ortiz N, Mangel JF, Wang J, Alfaro-Shigueto J and others (2016) Reducing green turtle bycatch in small-scale fisheries using illuminated gillnets: the cost of saving a sea turtle. Mar Ecol Prog Ser 545:251-259

Osorio A AF, Pelaez-Zapata DS, Guerrero-Gallego J, AlvarezSilva O, Osorio-Cano JD, Toro FM, Giraldo A (2014) Hidrodinámica aplicada a la gestión y la conservación de ecosistemas marinos y costeros: Isla Gorgona, Océano Pacífico Colombiano. Rev Biol Trop 62:133-147

Page-Karjian A, Torres F, Zhang J, Rivera S and others (2012) Presence of chelonid fibropapilloma-associated herpesvirus in tumored and non-tumored green turtles, as detected by polymerase chain reaction, in endemic and non-endemic aggregations, Puerto Rico. Springerplus 1:35

Page-Karjian A, Norton TM, Krimer P, Groner M, Nelson SE, Gottdenker NL (2014) Factors influencing survivorship of rehabilitating green sea turtles (Chelonia mydas) with fibropapillomatosis. J Zoo Wildl Med 45:507-519

Page-Karjian A, Norton TM, Harms C, Mader D and others (2015a) Case descriptions of fibropapillomatosis in rehabilitating loggerhead sea turtles Caretta caretta in the southeastern USA. Dis Aquat Org 115:185-191

* Page-Karjian A, Norton TM, Ritchie B, Brown C and others (2015b) Quantifying chelonid herpesvirus 5 in symptomatic and asymptomatic rehabilitating green sea turtles. Endang Species Res 28:135-146

Page-Karjian A, Rivera S, Torres F, Diez C, Moore D, Van Dam R, Brown C (2015c) Baseline blood values for healthy free-ranging green sea turtles (Chelonia mydas) in Puerto Rico. Comp Clin Pathol 24:567-573

Pajuelo M, Bjorndal KA, Reich KJ, Vander Zanden HB, Hawkes LA, Bolten AB (2012) Assignment of nesting loggerhead turtles to their foraging areas in the Northwest Atlantic using stable isotopes. Ecosphere 3:art89

Parga ML, Pons M, Andraka S, Rendon L and others (2015) Hooking locations in sea turtles incidentally captured by artisanal longline fisheries in the Eastern Pacific Ocean. Fish Res 164:231-237

* Parsons ECM, Baulch S, Bechshoft T, Bellazzi G and others (2015) Key research questions of global importance for cetacean conservation. Endang Species Res 27:113-118

Patel SH, Morreale SJ, Panagopoulou A, Bailey H and others (2015a) Changepoint analysis: a new approach for revealing animal movements and behaviors from satellite telemetry data. Ecosphere 6:art291

*Patel SH, Panagopoulou A, Morreale SJ, Kilham SS and others (2015b) Differences in size and reproductive output of loggerhead turtles Caretta caretta nesting in the eastern Mediterranean Sea are linked to foraging site. Mar Ecol Prog Ser 535:231-241

* Patino-Martinez J, Marco A, Quinones L, Hawkes LA (2014) The potential future influence of sea level rise on leatherback turtle nests. J Exp Mar Biol Ecol 461:116-123

* Patrício AR, Velez-Zuazo X, Diez CE, Van Dam R, Sabat AM (2011) Survival probability of immature green turtles in two foraging grounds at Culebra, Puerto Rico. Mar Ecol Prog Ser 440:217-227

*Patrício R, Diez CE, van Dam RP (2014) Spatial and temporal variability of immature green turtle abundance and somatic growth in Puerto Rico. Endang Species Res 23: $51-62$

*Patrício AR, Diez CE, van Dam RP, Godley BJ (2016) Novel insights into the dynamics of green turtle fibropapillomatosis. Mar Ecol Prog Ser 547:247-255

Peckham SH, Lucero-Romero J, Maldonado-Diaz D, Rodrigo-Sanchez A, Senko J, Wojakowski M, Gaos A (2016) Buoyless nets reduce sea turtle bycatch in coastal net fisheries. Conserv Lett 9:114-121

* Pelc RA, Max LM, Norden W, Roberts S, Silverstein R, Wilding SR (2015) Further action on bycatch could boost United States fisheries performance. Mar Policy 56:56-60

* Pendoley K, Kamrowski RL (2015) Influence of horizon elevation on the sea-finding behaviour of hatchling flatback turtles exposed to artificial light glow. Mar Ecol Prog Ser 529:279-288

*Pendoley KL, Bell CD, McCracken R, Ball KR and others (2014a) Reproductive biology of the flatback turtle Natator depressus in Western Australia. Endang Species Res 23:115-123

*Pendoley KL, Schofield G, Whittock PA, Ierodiaconou D, Hays GC (2014b) Multi-species benefits of a coastal marine turtle migratory corridor connecting Australian MPAs. Mar Biol 161:1455-1466

* Perrault J, Wyneken J, Thompson LJ, Johnson C, Miller DL (2011) Why are hatching and emergence success low? Mercury and selenium concentrations in nesting leatherback sea turtles (Dermochelys coriacea) and their young in Florida. Mar Pollut Bull 62:1671-1682

*Perrault JR, Miller DL, Eads E, Johnson C, Merrill A, Thompson LJ, Wyneken J (2012) Maternal health status correlates with nest success of leatherback sea turtles (Dermochelys coriacea) from Florida. PLOS ONE 7 : e31841

Perrault JR, Schmid JR, Walsh CJ, Yordy JE, Tucker AD (2014) Brevetoxin exposure, superoxide dismutase activity and plasma protein electrophoretic profiles in wild-caught Kemp's ridley sea turtles (Lepidochelys kempii) in southwest Florida. Harmful Algae 37:194-202

* Peterson CH, Fegley SR, Voss CM, Marschhauser SR, VanDusen BM (2013) Conservation implications of densitydependent predation by ghost crabs on hatchling sea turtles running the gauntlet to the sea. Mar Biol 160:629-640

* Petitet R, Avens L, Castilhos JC, Kinas PG, Bugoni L (2015) Age and growth of olive ridley sea turtles Lepidochelys olivacea in the main Brazilian nesting ground. Mar Ecol Prog Ser 541:205-218

* Pfaller JB, Limpus CJ, Bjorndal KA (2009) Nest site selection in individual loggerhead turtles and consequences for 
doomed-egg relocation. Conserv Biol 23:72-80

Pfaller JB, Bjorndal KA, Chaloupka M, Williams KL, Frick MG, Bolten AB (2013) Accounting for imperfect detection is critical for inferring marine turtle nesting population trends. PLOS ONE 8:e62326

Phillips KP, Jorgensen TH, Jolliffe KG, Jolliffe SM, Henwood J, Richardson DS (2013) Reconstructing paternal genotypes to infer patterns of sperm storage and sexual selection in the hawksbill turtle. Mol Ecol 22:2301-2312

Phillips KF, Mansfield KL, Die DJ, Addison DS (2014a) Survival and remigration probabilities for loggerhead turtles (Caretta caretta) nesting in the eastern Gulf of Mexico. Mar Biol 161:863-870

Phillips KP, Jorgensen TH, Jolliffe KG, Richardson DS (2014b) Potential inter-season sperm storage by a female hawksbill turtle. Mar Turtle Newsl 140:13-14

* Phillips KP, Mortimer JA, Jolliffe KG, Jorgensen TH, Richardson DS (2014c) Molecular techniques reveal cryptic life history and demographic processes of a critically endangered marine turtle. J Exp Mar Biol Ecol 455:29-37

Phillott AD, Parmenter CJ (2014) Fungal colonization of green sea turtle (Chelonia mydas) nests is unlikely to affect hatchling condition. Herpetol Conserv Biol 9:297-301

Pike DA (2013a) Climate influences the global distribution of sea turtle nesting. Glob Ecol Biogeogr 22:555-566

* Pike DA (2013b) Forecasting range expansion into ecological traps: climate-mediated shifts in sea turtle nesting beaches and human development. Glob Change Biol 19: 3082-3092

Pike DA (2014) Forecasting the viability of sea turtle eggs in a warming world. Glob Change Biol 20:7-15

* Pikesley SK, Broderick AC, Cejudo D, Coyne MS and others (2015) Modelling the niche for a marine vertebrate: a case study incorporating behavioural plasticity, proximate threats and climate change. Ecography 38:803-812

Pilcher NJ, Antonopoulou M, Perry L, Abdel-Moati MA and others (2014) Identification of important sea turtle areas (ITAs) for hawksbill turtles in the Arabian Region. J Exp Mar Biol Ecol 460:89-99

* Pilcher NJ, Al-Maslamani I, Williams J, Gasang R, Chikhi A (2015) Population structure of marine turtles in coastal waters of Qatar. Endang Species Res 28:163-174

Pirhalla DE, Sheridan SC, Ransibrahmanakul V, Lee CC (2015) Assessing cold-snap and mortality events in South Florida coastal ecosystems: development of a biological cold stress index using satellite SST and weather pattern forcing. Estuar Coasts 38:2310-2322

Piroddi C, Coll M, Steenbeek J, Moy DM, Christensen V (2015) Modelling the Mediterranean marine ecosystem as a whole: addressing the challenge of complexity. Mar Ecol Prog Ser 533:47-65

Plot V, Criscuolo F, Zahn S, Georges JY (2012) Telomeres, age and reproduction in a long-lived reptile. PLOS ONE 7:e40855.

* Plot V, de Thoisy B, Georges JY (2015) Dispersal and dive patterns during the post-nesting migration of olive ridley turtles from French Guiana. Endang Species Res 26: 221-234

Poli C, Lopez LCS, Mesquita DO, Saska C, Mascarenhas R (2014) Patterns and inferred processes associated with sea turtle strandings in Paraíba State, Northeast Brazil. Braz J Biol 74:283-289

Poli C, Mesquita DO, Saska C, Mascarenhas R (2015) Plastic ingestion by sea turtles in Paraiba State, Northeast Brazil. Iheringia Ser Zool 105:265-270
Pons M, Domingo A, Sales G, Fiedler FN, Miller P, Giffoni B, Ortiz M (2010) Standardization of CPUE of loggerhead sea turtle (Caretta caretta) caught by pelagic longliners in the southwestern Atlantic Ocean. Aquat Living Resour 23:65-75

*Prieto-Torres DA, Hernandez-Rangel J (2015) Breeding biology and hatching success of Chelonia mydas (Testudines: Cheloniidae) in Aves Island Wildlife Refuge, Venezuela, during the 2010 reproductive season. Rev Biol Trop 63:1059-1070

* Prieto-Torres DA, Hernandez JL, Henriquez AR, Alvarado MC, Davila MJ (2013) Blood biochemistry of the breeding population of green turtles (Chelonia mydas) in the Aves Island Wildlife Refuge, Venezuela. S Am J Herpetol 8:147-154

Prior B, Booth DT, Limpus CJ (2016) Investigating diet and diet switching in green turtles (Chelonia mydas). Aust J Zool 63:365-375

* Proietti MC, Reisser J, Marins LF, Marcovaldi MA and others (2014a) Hawksbill x loggerhead sea turtle hybrids at Bahia, Brazil: where do their offspring go? PeerJ 2:e255

* Proietti MC, Reisser J, Marins LF, Rodriguez-Zarate C and others (2014b) Genetic structure and natal origins of immature hawksbill turtles (Eretmochelys imbricata) in Brazilian waters. PLOS ONE 9:e88746

* Prosdocimi L, Dutton PH, Albareda D, Remis MI (2014) Origin and genetic diversity of leatherbacks (Dermochelys coriacea) at Argentine foraging grounds. J Exp Mar Biol Ecol 458:13-19

* Prosdocimi L, Bugoni L, Albareda D, Remis MI (2015) Are stocks of immature loggerhead sea turtles always mixed? J Exp Mar Biol Ecol 466:85-91

Pullin A, Knight T (2001) Effectiveness in conservation practice: pointers from medicine and public health. Conserv Biol 15:50-54

Pullin A, Knight T (2009) Doing more good than harm building an evidence-base for conservation and environmental management. Biol Conserv 142:931-934

* Pullin A, Knight T, Stone D, Charman K (2004) Do conservation managers use scientific evidence to support their decision-making? Biol Conserv 119:245-252

* Putman NF, Mansfield KL (2015) Direct evidence of swimming demonstrates active dispersal in the sea turtle 'lost years.' . Curr Biol 25:1221-1227

* Putman NF, Naro-Maciel E (2013) Finding the 'lost years' in green turtles: insights from ocean circulation models and genetic analysis. Proc R Soc B 280:20131468

* Putman NF, Bane JM, Lohmann KJ (2010a) Sea turtle nesting distributions and oceanographic constraints on hatchling migration. Proc R Soc B 277:3631-3637

*Putman NF, Shay TJ, Lohmann KJ (2010b) Is the geographic distribution of nesting in the Kemp's ridley turtle shaped by the migratory needs of offspring? Integr Comp Biol 50: 305-314

* Putman NF, Scott R, Verley P, Marsh R, Hays GC (2012a) Natal site and offshore swimming influence fitness and long-distance ocean transport in young sea turtles. Mar Biol 159:2117-2126

* Putman NF, Verley P, Shay TJ, Lohmann KJ (2012b) Simulating transoceanic migrations of young loggerhead sea turtles: merging magnetic navigation behavior with an ocean circulation model. J Exp Biol 215:1863-1870

* Putman NF, Mansfield KL, He R, Shaver DJ, Verley P (2013) Predicting the distribution of oceanic-stage Kemp's ridley sea turtles. Biol Lett 9: 20130345 
Putman NF, Alberto Abreu-Grobois F, Broderick AC, Ciofi C and others (2014) Numerical dispersal simulations and genetics help explain the origin of hawksbill sea turtles in Ascension Island. J Exp Mar Biol Ecol 450:98-108

Putman NF, Abreu-Grobois FA, Iturbe-Darkistade I, Putman EM, Richards PM, Verley P (2015a) Deepwater Horizon oil spill impacts to sea turtles could span the Atlantic. Biol Lett 11:20150596

* Putman NF, Verley P, Endres CS, Lohmann KJ (2015b) Magnetic navigation behavior and the oceanic ecology of young loggerhead sea turtles. J Exp Biol 218:1044-1050

* Quinones J, Garcia-Godos I, Llapapasca M, Van Ordt F, Paredes E (2015) The black sea turtle (Chelonia mydas agassizii) at Lobos de Tierra Island, northern Peru: high densities in small areas. S Am J Herpetol 10:178-186

Rafferty AR, Reina RD (2014) The influence of temperature on embryonic developmental arrest in marine and freshwater turtles. J Exp Mar Biol Ecol 450:91-97

Rafferty AR, Santidrián Tomillo P, Spotila JR, Paladino FV, Reina RD (2011) Embryonic death is linked to maternal identity in the leatherback turtle (Dermochelys coriacea). PLOS ONE 6:e21038

Rafferty AR, Evans RG, Scheelings TF, Reina RD (2013) Limited oxygen availability in utero may constrain the evolution of live-birth in reptiles. Am Nat 181:245-253

Ramirez MD, Avens L, Seminoff JA, Goshe LR, Heppell SS (2015) Patterns of loggerhead turtle ontogenetic shifts revealed through isotopic analysis of annual skeletal growth increments. Ecosphere 6:art244

Read AJ (2007) Do circle hooks reduce the mortality of sea turtles in pelagic longlines? A review of recent experiments. Biol Conserv 135:155-169

Read TC, Wantiez L, Werry JM, Farman R, Petro G, Limpus CJ (2014) Migrations of green turtles (Chelonia mydas) between nesting and foraging grounds across the Coral Sea. PLOS ONE 9:e100083

Red List Standards \& Petitions Subcommittee (1996) Natator depressus. The IUCN Red List of Threatened Species 1996: e.T14363A4435952. http://dx.doi.org/10.2305/IUCN. UK.1996.RLTS.T14363A4435952.en (acccessed 14 December 2016)

Redfoot W, Ehrhart L (2013) Trends in size class distribution, recaptures, and abundance of juvenile green turtles (Chelonia mydas) utilizing a rock riprap lined embayment at Port Canaveral, Florida, USA, as developmental habitat. Chelonian Conserv Biol 12:252-261

Rees AF, Margaritoulis D, Newman R, Riggall TE and others (2013) Ecology of loggerhead marine turtles Caretta caretta in a neritic foraging habitat: movements, sex ratios and growth rates. Mar Biol 160:519-529

Reinhold L (2015) Absence of ingested plastics in 20 necropsied sea turtles in Western Australia. Mar Turtle Newsl 144:13-15

Reintsma N, Young M, Salmon M (2014) Do lighthouses disrupt the orientation of sea turtle hatchlings? Hypothesis testing with arena assays at Hillsboro Beach, Florida, USA. Mar Turtle Newsl 140:1-3

Reising M, Salmon M, Stapleton S (2015) Hawksbill nest site selection affects hatchling survival at a rookery in Antigua, West Indies. Endang Species Res 29:179-187

Revuelta O, Leon YM, Balbuena JA, Broderick AC and others (2014) The value of endangered species in protected areas at risk: the case of the leatherback turtle in the Dominican Republic. Biodivers Conserv 23:1529-1539

* Revuelta O, Hawkes L, León YM, Godley BJ, Raga JA,
Tomás J (2015a) Evaluating the importance of marine protected areas for the conservation of hawksbill turtles Eretmochelys imbricata nesting in the Dominican Republic. Endang Species Res 27:169-180

* Revuelta O, León YM, Broderick AC, Feliz PA and others (2015b) Assessing the efficacy of direct conservation interventions: clutch protection of the leatherback marine turtle in the Dominican Republic. Oryx 49:677-686

* Richardson B (2003) Impact of aging on DNA methylation. Ageing Res Rev 2:245-261

Richardson PB, Bruford MW, Calosso MC, Campbell LM and others (2009) Marine turtles in the Turks and Caicos Islands: remnant rookeries, regionally significant foraging stocks, and a major turtle fishery. Chelonian Conserv Biol 8:192-207

* Rings CC, Rafferty AR, Guinea ML, Reina RD (2015) The impact of extended preovipositional arrest on embryonic development and hatchling fitness in the flatback sea turtle. Physiol Biochem Zool 88:116-127

* Riskas KA, Fuentes MM, Hamann M (2016) Justifying the need for collaborative management of fisheries bycatch: a lesson from marine turtles in Australia. Biol Conserv 196:40-47

* Rivas ML, Santidrián Tomillo P, Uribeondo JD, Marco A (2015) Leatherback hatchling sea-finding in response to artificial lighting: interaction between wavelength and moonlight. J Exp Mar Biol Ecol 463:143-149

Robinson NJ, Figgener C (2015) Plastic straw found inside the nostril of an olive ridley sea turtle. Mar Turtle Newsl 147:5-6

Kobinson NJ, Valentine SE, Santidrián Tomillo P, Saba VS, Spotila JR, Paladino FV (2014) Multidecadal trends in the nesting phenology of Pacific and Atlantic leatherback turtles are associated with population demography. Endang Species Res 24:197-206

* Rocha Júnior JC, Pfaller JB, Corbetta R, Verissimo L (2015) Parasitic isopods associated with sea turtles nesting in Brazil. J Mar Biol Assoc UK 95:973-981

* Rodenbusch CR, Almeida LL, Marks FS, Ataíde MW and others (2012) Detection and characterization of fibropapilloma associated herpesvirus of marine turtles in Rio Grande do Sul, Brazil. Pesqui Vet Bras 32:1179-1183

* Rodenbusch CR, Baptistotte C, Werneck MR, Pires TT and others (2014) Fibropapillomatosis in green turtles Chelonia mydas in Brazil: characteristics of tumors and virus. Dis Aquat Org 111:207-217

Roe JH, Morreale SJ, Paladino FV, Shillinger GL and others (2014) Predicting bycatch hotspots for endangered leatherback turtles on longlines in the Pacific Ocean. Proc R Soc B 281:20132559

Rossi AS, Gattamorta MA, Prioste FES, Lima EHSM and others (2015) Fibropapillomas in a loggerhead sea turtle (Caretta caretta) caught in Almofala, Ceará, Brazil: histopathological and molecular characterizations. Mar Turtle Newsl 147:12-16

Ruggiero MG, Ferretti L, Glomski C, Pica A (2014) Erythrophagocytosis in circulating blood of loggerhead turtles Caretta caretta: the pitting of Heinz bodies. J Exp Zool A 321:144-150

* Ryan PG (2016) Ingestion of plastics by marine organisms. In: Takada H, Karapanagioti HK (eds) Hazardous chemicals associated with plastics in the marine environment. Handbook of environmental chemistry. Springer, Berlin, p 1-32

Sáenz-Arroyo AC, Roberts M, Torre J, Cariño-Olvera M 
(2005) Using fishers' anecdotes, naturalists' observations and grey literature to reassess marine species at risk: the case of the Gulf grouper in the Gulf of California, Mexico. Fish Fish 6:121-133

Saito T, Kurita M, Okamoto H, Uchida I, Parker D, Balazs G (2015) Tracking male loggerhead turtle migrations around southwestern Japan using satellite telemetry. Chelonian Conserv Biol 14:82-87

* Sampson L, Payan LF, Amorocho DF, Seminoff JA, Giraldo A (2014) Intraspecific variation of the green turtle, Chelonia mydas (Cheloniidae), in the foraging area of Gorgona Natural National Park (Colombian Pacific). Acta Biol Colomb 19:461-470

Sánchez-Sarmiento AM, Rossi S, Vilca FZ, Thijl Vanstreels RE and others (2016) Organochlorine pesticides in green sea turtles (Chelonia mydas) with and without fibropapillomatosis caught at three feeding areas off Brazil. J Mar Biol Assoc UK, doi:10.1017/S002531541500226X

Sandbrook C, Adams WM, Büscher B, Vira B (2013) Social research and biodiversity conservation. Conserv Biol 27: $1487-1490$

Santidrián Tomillo P, Saba VS, Piedra R, Paladino FV, Spotila JR (2008) Effects of illegal harvest of eggs on the population decline of leatherback turtles in Las Baulas Marine National Park, Costa Rica. Conserv Biol 22: 1216-1224

Santidrián Tomillo P, Oro D, Paladino FV, Piedra R, Sieg AE, Spotila JR (2014) High beach temperatures increased female-biased primary sex ratios but reduced output of female hatchlings in the leatherback turtle. Biol Conserv 176:71-79

Santidrián Tomillo P, Genovart M, Paladino FV, Spotila JR, Oro D (2015a) Climate change overruns resilience conferred by temperature-dependent sex determination in sea turtles and threatens their survival. Glob Change Biol 21:2980-2988

Santidrián Tomillo P, Saba VS, Lombard CD, Valiulis JM and others (2015b) Global analysis of the effect of local climate on the hatchling output of leatherback turtles. Sci Rep 5:16789

Santoro M, Morales JA, Bolanos F, Chaves G, De Stefano M (2015) Helminths of hawksbill turtle (Eretmochelys imbricata) from the Pacific coast of Costa Rica. Helminthologia 52:67-70

Santos RG, Andrades R, Boldrini MA, Martins AS (2015a) Debris ingestion by juvenile marine turtles: an underestimated problem. Mar Pollut Bull 93:37-43

Santos RG, Martins AS, Batista MB, Horta PA (2015b) Regional and local factors determining green turtle Chelonia mydas foraging relationships with the environment. Mar Ecol Prog Ser 529:265-277

Santos AJB, Neto JXL, Vieira DHG, Neto LD and others (2016) Individual nest site selection in hawksbill turtles within and between nesting seasons. Chelonian Conserv Biol 15:109-114

Sarı F, Kaska Y (2015) Loggerhead sea turtle hatchling sex ratio differences between two nesting beaches in Turkey. Isr J Ecol Evol 61:115-129

Sarmiento-Ramírez JM, Abella-Perez E, Phillott AD, Sim J and others (2014a) Global distribution of two fungal pathogens threatening endangered sea turtles. PLOS ONE 9:e85853

Sarmiento-Ramírez JM, van der Voort M, Raaijmakers JM, Diéguez-Uribeondo J (2014b) Unravelling the microbiome of eggs of the endangered sea turtle Eretmochelys imbricata identifies bacteria with activity against the emerging pathogen Fusarium falciforme. PLOS ONE 9:e95206

* Sasso CR, Braun-McNeill J, Avens L, Epperly SP (2007) Summer abundance estimates of Caretta caretta (loggerhead turtles) in Core Sound, NC. Southeast Nat 6: 365-369

* Scales KL, Miller PI, Hawkes LA, Ingram SN, Sims DW, Votier SC (2014) On the front line: frontal zones as priority at-sea conservation areas for mobile marine vertebrates. J Appl Ecol 51:1575-1583

* Scales KL, Miller PI, Varo-Cruz N, Hodgson DJ, Hawkes LA, Godley BJ (2015) Oceanic loggerhead turtles Caretta caretta associate with thermal fronts: evidence from the Canary Current Large Marine Ecosystem. Mar Ecol Prog Ser 519:195-207

Schlüter A, Madrigal R (2012) The SES framework in a marine setting: methodological lessons. RMM 3:148-167

Schneider GF, Dekker C (2012) DNA sequencing with nanopores. Nat Biotechnol 30:326-328

Schneller AJ, Irizarry A (2014) Imaging conservation: sea turtle murals and their effect on community pro-environmental attitudes in Baja California Sur, Mexico. Ocean Coast Manage 89:100-111

* Schofield G, Dimadi A, Fossette S, Katselidis KA and others (2013) Satellite tracking large numbers of individuals to infer population level dispersal and core areas for the protection of an endangered species. Divers Distrib 19: 834-844

* Schofield G, Scott R, Katselidis KA, Mazaris AD, Hays GC (2015) Quantifying wildlife-watching ecotourism intensity on an endangered marine vertebrate. Anim Conserv 18:517-528

* Schroeder AL, Metzger KJ, Miller A, Rhen T (2016) A novel candidate gene for temperature-dependent sex determination in the common snapping turtle. Genetics 203: $557-571$

Schumacher VL, Mangold B, Lenzycki J, Hinckley L, Sutton DA, Frasca S Jr (2014) Occurrence of fruiting structures allows determination of Purpureocillium lilacinum as an inciting agent of pleuritis and pneumonia in a loggerhead sea turtle (Caretta caretta) by histopathologic correlation to culture. Med Mycol Case Rep 6:42-45

* Schuyler Q, Hardesty BD, Wilcox C, Townsend KA (2014a) Global analysis of anthropogenic debris ingestion by sea turtles. Conserv Biol 28:129-139

* Schuyler QA, Wilcox C, Townsend K, Hardesty BD, Marshall NJ (2014b) Mistaken identity? Visual similarities of marine debris to natural prey items of sea turtles. BMC Ecol 14:14

Schuyler QA, Wilcox C, Townsend K, Wedemeyer-Strombel KR, Balazs G, van Sebille E, Hardesty BD (2016) Risk analysis reveals global hotspots for marine debris ingestion by sea turtles. Glob Change Biol 22:567-576

Schwanz LE, Cordero GA, Charnov EL, Janzen FJ (2016) Sex-specific survival to maturity and the evolution of environmental sex determination. Evolution 70: 329-341

* Scott R, Marsh R, Hays GC (2012a) A little movement orientated to the geomagnetic field makes a big difference in strong flows. Mar Biol 159:481-488

Scott R, Marsh R, Hays GC (2012b) Life in the really slow lane: loggerhead sea turtles mature late relative to other reptiles. Funct Ecol 26:227-235

Scott R, Hodgson DJ, Witt MJ, Coyne MS and others (2012c) 
Global analysis of satellite tracking data shows that adult green turtles are significantly aggregated in Marine Protected Areas. Glob Ecol Biogeogr 21:1053-1061

Scott R, Biastoch A, Roder C, Stiebens VA, Eizaguirre C (2014a) Nano-tags for neonates and ocean-mediated swimming behaviours linked to rapid dispersal of hatchling sea turtles. Proc R Soc B 281:20141209

Scott R, Marsh R, Hays GC (2014b) Ontogeny of long distance migration. Ecology 95:2840-2850

Sellera FP, Sabino CP, Fernandes LT, Pogliani FC and others (2014) Green turtle (Chelonia mydas) cutaneous fibropapillomatosis treatment by photodynamic therapy. Mar Turtle Newsl 142:6-10

Seminoff JA, Shanker K (2008) Marine turtles and IUCN Red Listing: a review of the process, the pitfalls, and novel assessment approaches. J Exp Mar Biol Ecol 356:52-68

Seminoff JA, Benson SR, Arthur KE, Eguchi T and others (2012) Stable isotope tracking of endangered sea turtles: validation with satellite telemetry and $\delta^{15} \mathrm{~N}$ analysis of amino acids. PLOS ONE 7:e37403

Seminoff JA, Eguchi T, Carretta J, Allen CD and others (2014) Loggerhead sea turtle abundance at a foraging hotspot in the eastern Pacific Ocean: implications for atsea conservation. Endang Species Res 24:207-220

Seminoff JA, Allen CD, Balazs GH, Dutton PH and others (2015) Status review of the green turtle (Chelonia mydas) under the Endangered Species Act. NOAA Tech Memo NOAA-NMFS- SWFSC-539

Senko J, Mancini A, Seminoff JA, Koch V (2014a) Bycatch and directed harvest drive high green turtle mortality at Baja California Sur, Mexico. Biol Conserv 169:24-30

Senko J, White ER, Heppell SS, Gerber LR (2014b) Comparing bycatch mitigation strategies for vulnerable marine megafauna. Anim Conserv 17:5-18

Shamblin BM, Bjorndal KA, Bolten AB, Hillis-Starr ZM, Lundgren I, Naro-Maciel E, Nairn CJ (2012a) Mitogenomic sequences better resolve stock structure of southern Greater Caribbean green turtle rookeries. Mol Ecol 21:2330-2340

Shamblin BM, Bolten AB, Bjorndal KA, Dutton PH and others (2012b) Expanded mitochondrial control region sequences increase resolution of stock structure among North Atlantic loggerhead turtle rookeries. Mar Ecol Prog Ser 469:145-160

* Shamblin BM, Bolten AB, Abreu-Grobois FA, Bjorndal KA and others (2014) Geographic patterns of genetic variation in a broadly distributed marine vertebrate: new insights into loggerhead turtle stock structure from expanded mitochondrial DNA sequences. PLOS ONE 9: e85956

Shamblin BM, Bagley DA, Ehrhart LM, Desjardin NA and others (2015a) Genetic structure of Florida green turtle rookeries as indicated by mitochondrial DNA control region sequences. Conserv Genet 16:673-685

* Shamblin BM, Dutton PH, Bjorndal KA, Bolten AB and others (2015b) Deeper mitochondrial sequencing reveals cryptic diversity and structure in Brazilian green turtle rookeries. Chelonian Conserv Biol 14:167-172

Shamblin BM, Bagley DA, Ehrhart LM, Nairn CJ (2015c) Mitochondrial repeat haplotypes suggest local origins for CM-A13 green turtles foraging in Florida. Mar Turtle Newsl 146:11-13

Shaver DJ, Caillouet CW Jr (2015) Reintroduction of Kemp's ridley (Lepidochelys kempii) sea turtle to Padre Island National Seashore, Texas and its connection to head- starting. Herpetol Conserv Biol 10:378-435

* Shaver DJ, Hart KM, Fujisaki I, Rubio C and others (2016) Migratory corridors of adult female Kemp's ridley turtles in the Gulf of Mexico. Biol Conserv 194:158-167

* Shimada T, Aoki S, Kameda K, Hazel J, Reich K, Kamezaki N (2014) Site fidelity, ontogenetic shift and diet composition of green turtles Chelonia mydas in Japan inferred from stable isotope analysis. Endang Species Res 25: 151-164

Shimada T, Limpus C, Jones R, Hazel J, Groom R, Hamann M (2016) Sea turtles return home after intentional displacement from coastal foraging areas. Mar Biol 163: $1-14$

Sifuentes-Romero I, Merchant-Larios H, Milton S, MorenoMendoza N and others (2013) RNAi-mediated gene silencing in a gonad organ culture to study sex determination mechanisms in sea turtle. Genes (Basel) 4: 293-305

Sigler M (2014) The effects of plastic pollution on aquatic wildlife: current situations and future solutions. Water Air Soil Pollut 225:2184

* Sim EL, Booth DT, Limpus CJ (2015) Incubation temperature, morphology and performance in loggerhead (Caretta caretta) turtle hatchlings from Mon Repos, Queensland, Australia. Biol Open 4:685-692

Simoes TN, da Silva AC, dos Santos EM, Chagas CA (2014) Temperature of incubation and sex ratios in the recentlyhatched young ones of the sea turtle Eretmochelys imbricata (Linnaeus, 1766) in the municipality of Ipojuca, pernambuco, Brazil. Pap Avulsos Zool (Sao Paulo) 54: 363-374

* Sims M, Bjorkland R, Mason P, Crowder LB (2008) Statistical power and sea turtle nesting beach surveys: How long and when? Biol Conserv 141:2921-2931

Singh R, Weninger Q (2015) Cap-and-trade bycatch management with costly avoidance and stock uncertainty. Mar Resour Econ 30:97-119

* Smolowitz R, Patel SH, Haas H, Miller SA (2015) Using a remotely operated vehicle (ROV) to observe loggerhead sea turtle (Caretta caretta) behavior on foraging grounds off the mid-Atlantic United States. J Exp Mar Biol Ecol 471:84-91

Snover ML, Hohn AA (2004) Validation and interpretation of annual skeletal marks in loggerhead (Caretta caretta) and Kemp's ridley (Lepidochelys kempii) sea turtles. Fish Bull 102:682-692

* Stacy NI, Innis CJ, Hernandez JA (2013) Development and evaluation of three mortality prediction indices for coldstunned kemp's ridley sea turtles (Lepidochelys kempii). Conserv Physiol 1:cot003

Stacy BA, Innis CJ, Daoust PY, Wyneken J and others (2015) Solitary large intestinal diverticulitis in leatherback turtles (Dermochelys coriacea). Vet Pathol 52:712-715

* Stadler M, Salmon M, Roberts C (2015) Ecological correlates of green turtle (Chelonia mydas) abundance on the nearshore Worm Reefs of Southeastern Florida. J Coast Res 31:244-254

* Sterling EJ, Mcfadden KW, Holmes KE, Vintinner ECA, Arengo F, Naro-Maciel E (2013) Ecology and conservation of marine turtles in a central pacific foraging ground. Chelonian Conserv Biol 12:2-16

Stewart KR, Dutton PH (2014) Breeding sex ratios in adult leatherback turtles (Dermochelys coriacea) may compensate for female-biased hatchling sex ratios. PLOS ONE 9:e88138 
Stewart K, Mitchell MA, Norton T, Krecek RC (2012) Measuring the level of agreement in hematologic and biochemical values between blood sampling sites in leatherback sea turtles (Dermochelys coriacea). J Zoo Wildl Med 43:719-725

Stewart KR, James MC, Roden S, Dutton PH (2013) Assignment tests, telemetry and tag-recapture data converge to identify natal origins of leatherback turtles foraging in Atlantic Canadian waters. J Anim Ecol 82:791-803

Stewart KR, Martin KJ, Johnson C, Desjardin N, Eckert SA, Crowder LB (2014) Increased nesting, good survival and variable site fidelity for leatherback turtles in Florida, USA. Biol Conserv 176:117-125

Stokes KL, Fuller WJ, Glen F, Godley BJ and others (2014) Detecting green shoots of recovery: the importance of long-term individual-based monitoring of marine turtles. Anim Conserv 17:593-602

Stokes KL, Broderick AC, Canbolat AF, Candan O and others (2015) Migratory corridors and foraging hotspots: critical habitats identified for Mediterranean green turtles. Divers Distrib 21:665-674

* Storelli MM, Zizzo N (2014) Occurrence of organochlorine contaminants (PCBs, PCDDs and PCDFs) and pathologic findings in loggerhead sea turtles, Caretta caretta, from the Adriatic Sea (Mediterranean Sea). Sci Total Environ 472:855-861

Stringell TB, Clerveaux WV, Godley BJ, Phillips Q and others (2015a) Protecting the breeders: research informs legislative change in a marine turtle fishery. Biodivers Conserv 24:1775-1796

Stringell TB, Clerveaux WV, Godley BJ, Phillips Q and others (2015b) Fisher choice may increase prevalence of green turtle fibropapillomatosis disease. Front Mar Sci 2:57

Sutherland WJ, Pullin A, Dolman P, Knight T (2004) The need for evidence-based conservation. Trends Ecol Evol 19:305-308

Sutherland WJ, Armstrong-Brown S, Armsworth PR, Brereton $\mathrm{T}$ and others (2006) The identification of 100 ecological questions of high policy relevance in the UK. J Appl Ecol 43:617-627

Sutherland WJ, Adams WM, Aronson RB, Aveling R and others (2009) One hundred questions of importance to the conservation of global biological diversity. Conserv Biol 23:557-567

Swarthout RF, Keller JM, Peden-Adams M, Landry AM, Fair PA, Kucklick JR (2010) Organohalogen contaminants in blood of Kemp's ridley (Lepidochelys kempii) and green sea turtles (Chelonia mydas) from the Gulf of Mexico. Chemosphere 78:731-741

Swimmer Y, Arauz R, McCracken M, McNaughton L and others (2006) Diving behavior and delayed mortality of olive ridley sea turtles Lepidochelys olivacea after their release from longline fishing gear. Mar Ecol Prog Ser 323:253-261

* Swimmer Y, Empey Campora C, McNaughton L, Musyl M, Parga M (2014) Post-release mortality estimates of loggerhead sea turtles (Caretta caretta) caught in pelagic longline fisheries based on satellite data and hooking location. Aquat Conserv 24:498-510

* Tamura S, Shiode D, Kaneko Y, Fu F, Tokai T, Kobayashi M, Abe O (2014) Behavior of sea turtles to a turtle releasing device (TRD) for set nets of the mid-water and sea-bottom bagnet type. Bull Jpn Soc Sci Fish 80:900-907

Tanner C (2014) Sea turtle bycatch off the western region of the Ghanaian Coast. Mar Turtle Newsl 140:8-11
Tedeschi JN, Mitchell NJ, Berry O, Whiting S, Meekan M, Kennington WJ (2014) Reconstructed paternal genotypes reveal variable rates of multiple paternity at three rookeries of loggerhead sea turtles (Caretta caretta) in Western Australia. Aust J Zool 62:454-462

Tedeschi JN, Kennington WJ, Berry O, Whiting S, Meekan M, Mitchell NJ (2015) Increased expression of Hsp70 and Hsp90 mRNA as biomarkers of thermal stress in loggerhead turtle embryos (Caretta caretta). J Therm Biol 47: 42-50

Teh LSL, Teh LCL, Hines E, Junchompoo C, Lewison RL (2015) Contextualising the coupled socio-ecological conditions of marine megafauna bycatch. Ocean Coast Manage 116:449-465

*Thomson JA, Burkholder DA, Heithaus MR, Fourqurean JW, Fraser MW, Statton J, Kendrick GA (2015a) Extreme temperatures, foundation species, and abrupt ecosystem change: an example from an iconic seagrass ecosystem. Glob Change Biol 21:1463-1474

* Thomson JA, Gulick A, Heithaus MR (2015b) Intraspecific behavioral dynamics in a green turtle Chelonia mydas foraging aggregation. Mar Ecol Prog Ser 532:243-256

* Tikochinski Y, Bendelac R, Barash A, Daya A, Levy Y, Friedmann A (2012) Mitochondrial DNA STR analysis as a tool for studying the green sea turtle (Chelonia mydas) populations: the Mediterranean Sea case study. Mar Genomics 6:17-24

Tisdell C, Tisdell CA (2014a) The hawksbill turtle - its conservation and use: public values, attitudes and policies. In: Tisdell CA (ed) Human values and biodiversity conservation: the survival of wild species. Edward Elgar Publishing, Cheltenham, p 157-179

Tisdell C, Tisdell CA (2014b) Public support for conserving reptile species: stated values for different species and comparative support for their conservation. In: Tisdell CA (ed) Human values and biodiversity conservation: the survival of wild species. Edward Elgar Publishing, Cheltenham, p 209-233

Tisdell C, Tisdell CA (2014c) Changed values and increased support for wildlife conservation as a result of ecotourism: a sea turtle study. In: Tisdell CA (ed) Human values and biodiversity conservation: the survival of wild species. Edward Elgar Publishing, Cheltenham, p 43-58

Tiwari M, Bjorndal KA, Bolten AB, Bolker BM (2005) Intraspecific application of the mid-domain effect model: spatial and temporal nest distributions of green turtles, Chelonia mydas, at Tortuguero, Costa Rica. Ecol Lett 8: 918-924

* Tonay AM, Danyer E, Dede A, Öztürk B, Öztürk AA (2016) The stomach content of a Mediterranean monk seal (Monachus monachus): finding of green turtle (Chelonia mydas) remains. Zool Middle East 62:212-216

Trujillo-Arias N, Amorocho DF, Lopez-Alvarez D, MejiaLadino LM (2014) Phylogeographic relations of some feeding and nesting of hawksbill turtle rookeries (Eretmochelys imbricata) in the Caribbean and Pacific of Colombia. Bol Investig Mar Cost 43:159-182

* Tucek J, Nel R, Girondot M, Hughes G (2014) Age-size relationship at reproduction of South African female loggerhead turtles Caretta caretta. Endang Species Res 23: $167-175$

Tucker AD (2010) Nest site fidelity and clutch frequency of loggerhead turtles are better elucidated by satellite telemetry than by nocturnal tagging efforts: implications for stock estimation. J Exp Mar Biol Ecol 383:48-55 
Tucker AD, MacDonald BD, Seminoff JA (2014) Foraging site fidelity and stable isotope values of loggerhead turtles tracked in the Gulf of Mexico and northwest Caribbean. Mar Ecol Prog Ser 502:267-279

* Turner-Tomaszewicz CN, Seminoff JA, Avens L, Goshe LR, Peckham SH, Rguez-Baron JM, Kurle CM (2015) Age and residency duration of loggerhead turtles at a North Pacific bycatch hotspot using skeletochronology. Biol Conserv 186:134-142

* Uçar AH, Kaska Y, Ergene S, Aymak C and others (2012) Sex ratio estimation of the most eastern main loggerhead sea turtle nesting site: Anamur beach, Mersin, Turkey. Isr J Ecol Evol 58:87-100

Ullmann J, Stachowitsch M (2015) A critical review of the Mediterranean sea turtle rescue network: a web looking for a weaver. Nat Conserv 10:45-69

* Valverde RA, Orrego CM, Tordoir MT, Gómez FM and others (2012) Olive ridley mass nesting ecology and egg harvest at Ostional Beach, Costa Rica. Chelonian Conserv Biol 11:1-11

van de Merwe JP, Hodge M, Olszowy HA, Whittier JM, Ibrahim K, Lee SY (2009) Chemical contamination of green turtle (Chelonia mydas) eggs in peninsular Malaysia: implications for conservation and public health. Environ Health Perspect 117:1397-1401

van de Merwe JP, Hodge M, Whittier JM, Ibrahim K, Lee SY (2010) Persistent organic pollutants in the green sea turtle Chelonia mydas: nesting population variation, maternal transfer, and effects on development. Mar Ecol Prog Ser 403:269-278

van de Merwe JP, West EJ, Ibrahim K (2012) Effects of offroad vehicle tyre ruts on the beach dispersal of green sea turtle Chelonia mydas hatchlings. Endang Species Res 18:27-34

* Van Houtan KS, Kittinger JN (2014) Historical commercial exploitation and the current status of Hawaiian green turtles. Biol Conserv 170:20-27

*Van Houtan KS, Hargrove SK, Balazs GH (2010) Land use, macroalgae, and a tumor-forming disease in marine turtles. PLOS ONE 5:e12900

Van Houtan KS, Hargrove SK, Balazs GH (2014a) Modeling sea turtle maturity age from partial life history records. Pac Sci 68:465-477

*Van Houtan KS, Smith CM, Dailer ML, Kawachi M (2014b) Eutrophication and the dietary promotion of sea turtle tumors. PeerJ 2:e602

V Van Houtan KS, Francke DL, Alessi S, Jones TT and others (2016) The developmental biogeography of hawksbill sea turtles in the North Pacific. Ecol Evol 6:2378-2389

*Vander Zanden HB, Bjorndal KA, Inglett PW, Bolten AB (2012) Marine-derived nutrients from green turtle nests subsidize terrestrial beach ecosystems. Biotropica 44 : 294-301

Vander Zanden HB, Bjorndal KA, Bolten AB (2013) Temporal consistency and individual specialization in resource use by green turtles in successive life stages. Oecologia 173:767-777

Vander Zanden HB, Pfaller JB, Reich KJ, Pajuelo M and others (2014) Foraging areas differentially affect reproductive output and interpretation of trends in abundance of loggerhead turtles. Mar Biol 161:585-598

Vander Zanden HB, Tucker AD, Hart KM, Lamont ML and others (2015) Determining origin in a migratory marine vertebrate: a novel method to integrate stable isotopes and satellite tracking. Ecol Appl 25:320-335
Vander Zanden $\mathrm{HB}$, Bolten $\mathrm{AB}$, Tucker $\mathrm{AD}$, Hart KM and others (2016) Biomarkers reveal sea turtles remained in oiled areas following the Deepwater Horizon oil spill. Ecol Appl. doi:10.1002/eap.1366

*Vargas SM, Jensen MP, Ho SYW, Mobaraki A and others (2016) Phylogeography, genetic diversity, and management units of hawksbill turtles in the Indo-Pacific. J Hered 107:199-213

* Varo-Cruz N, Bermeja JA, Calabuig P, Cejudo C and others (2016) New findings about the spatial and temporal use of the eastern Atlantic Ocean by large juvenile loggerhead turtles. Divers Distrib 22:481-492

Varriale A, Bernardi G (2006) DNA methylation in reptiles. Gene 385:122-127

Vegter AC, Barletta M, Beck C, Borrero J and others (2014) Global research priorities to mitigate plastic pollution impacts on marine wildlife. Endang Species Res 25:225-247

*Velez-Zuazo X, Quiñones J, Pacheco AS, Klinge L and others (2014) Fast growing, healthy and resident green turtles (Chelonia mydas) at two neritic sites in the central and northern coast of Peru: implications for conservation. PLOS ONE 9:e113068

*Venegas D, Marmolejo-Valencia A, Valdes-Quezada C, Govenzensky $\mathrm{T}$ and others (2016) Dimorphic DNA methylation during temperature-dependent sex determination in the sea turtle Lepidochelys olivacea. Gen Comp Endocrinol 236:35-41

* Veríssimo D, Jones DA, Chaverri R, Meyer SR (2012) Jaguar Panthera onca predation of marine turtles: conflict between flagship species in Tortuguero, Costa Rica. Oryx 46:340-347

*Viet Anh P, De Laender F, Everaert G, Chu Tien Vinh CT, Goethals P (2014) An integrated food web model to test the impact of fisheries management scenarios on the coastal ecosystem of Vietnam. Ocean Coast Manage 92: $74-86$

Villa CA, Finlayson S, Limpus C, Gaus C (2015) A multi-element screening method to identify metal targets for blood biomonitoring in green sea turtles (Chelonia mydas). Sci Total Environ 512-513:613-621

Wabnitz CCC, Balazs G, Beavers S, Bjorndal KA and others (2010) Ecosystem structure and processes at Kaloko Honok hau, focusing on the role of herbivores, including the green sea turtle Chelonia mydas, in reef resilience. Mar Ecol Prog Ser 420:27-44

WWalcott J, Horrocks JA (2014) Design of a protected area for inter-nesting hawksbills in Barbados: an evidence-based approach. Bull Mar Sci 90:969-987

*Walcott J, Eckert S, Oxenford HA, Horrocks JA (2014) Use of a towed camera system to investigate benthic habitat use by inter-nesting female hawksbill sea turtles. Endang Species Res 24:159-170

*Wallace BP, DiMatteo AD, Hurley BJ, Finkbeiner EM and others (2010) Regional management units for marine turtles: a novel framework for prioritizing conservation and research across multiple scales. PLOS ONE 5:e15465

Wallace BP, DiMatteo AD, Bolten AB, Chaloupka MY and others (2011) Global conservation priorities for marine turtles. PLOS ONE 6:e24510

* Wallace BP, Kot CY, DiMatteo AD, Lee T, Crowder LB, Lewison RL (2013) Impacts of fisheries bycatch on marine turtle populations worldwide: toward conservation and research priorities. Ecosphere 4:art40

*Wallace BP, Schumacher J, Seminoff JA, James MC (2014) Biological and environmental influences on the trophic 
ecology of leatherback turtles in the northwest Atlantic Ocean. Mar Biol 161:1711-1724

Wang J, Fisler S, Swimmer Y (2010) Developing visual deterrents to reduce sea turtle bycatch in gill net fisheries. Mar Ecol Prog Ser 408:241-250

Wang J, Barkan J, Fisler S, Godinez-Reyes C, Swimmer Y (2013a) Developing ultraviolet illumination of gillnets as a method to reduce sea turtle bycatch. Biol Lett 9: 20130383

Wang H, Tong J, Bi Y, Wang C, Guo L, Lu Y (2013b) Evaluation of mercury mediated in vitro cytotoxicity among cell lines established from green sea turtles. Toxicol In Vitro 27:1025-1030

Warden ML (2011) Modeling loggerhead sea turtle (Caretta caretta) interactions with US Mid-Atlantic bottom trawl gear for fish and scallops, 2005-2008. Biol Conserv 144:2202-2212

* Warden ML, Haas HL, Rose KA, Richards PM (2015) A spatially explicit population model of simulated fisheries impact on loggerhead sea turtles (Caretta caretta) in the Northwest Atlantic Ocean. Ecol Modell 299:23-39

Watson JT, Bigelow KA (2014) Trade-offs among catch, bycatch, and landed value in the American Samoa longline fishery. Conserv Biol 28:1012-1022

Webb SJ, Zychowski GV, Bauman SW, Higgins BM and others (2014) Establishment, characterization, and toxicological application of loggerhead sea turtle (Caretta caretta) primary skin fibroblast cell cultures. Environ Sci Technol 48:14728-14737

Weber SB, Broderick AC, Groothuis TGG, Ellick J, Godley BJ, Blount JD (2012) Fine-scale thermal adaptation in a green turtle nesting population. Proc R Soc B 279: 1077-1084

Weber SB, Weber N, Ellick J, Avery A and others (2014) Recovery of the South Atlantic's largest green turtle nesting population. Biodivers Conserv 23:3005-3018

Weiss K, Hamann M, Kinney M, Marsh H (2012) Knowledge exchange and policy influence in a marine resource governance network. Glob Environ Change 22:178-188

* Weiss K, Hamann M, Marsh H (2013) Bridging knowledges: understanding and applying indigenous and western scientific knowledge for marine wildlife management. Soc Nat Resour 26:285-302

Wells ML, Trainer VL, Smayda TJ, Karlson BSO and others (2015) Harmful algal blooms and climate change: learning from the past and present to forecast the future. Harmful Algae 49:68-93

*Werneck MR, Silva RJ (2015) Helminth parasites of juvenile green turtles Chelonia mydas (testudines: Cheloniidae) in Brazil. J Parasitol 101:713-716

Werneck MR, Baldassin P, D'Azeredo F, Trazi A, Berger B (2014) The hawksbill sea turtle Eretmochelys imbricata Linnaeus 1758 (Testudines, Cheloniidae) as new host of Hapalotrema postorchis Rao, 1976 (Digenea: Spirorchiidae). Comp Parasitol 81:75-78

* Werneck MR, Binoti E, Martins IVF, De Calais Junior A and others (2015a) Occurrence of Rhytidodoides similis Price, 1939 (Digenea: Rhytidodidae) and lesions due to spirorchiid eggs in a green turtle, Chelonia mydas Linnaeus, 1758 (Testudines, Cheloniidae), from Brazil. Comp Parasitol 82:291-295

Werneck MR, Lima EHSM, Pires T, Silva RJ (2015b) Helminth parasites of the juvenile hawksbill turtle Eretmochelys imbricata (Testudines: Cheloniidae) in Brazil. J Parasitol 101:500-503
Werneck MR, Souza GB, Berger BC, Trazzi A and others (2015c) Pathological changes by Hapalotrema postorchis Rao 1976 (Digenea: Spirorchiidae) in a green turtle Chelonia mydas Linnaeus 1758 (Testudines, Cheloniidae) from Brazil. Helminthologia 52:148-154

Werneck MR, Sousa VR, Trazi A, Berger B (2015d) Monticellius indicum Mehra, 1939 (Digenea: Spirorchiidae) in a hawksbill turtle, Eretmochelys imbricata Linnaeus 1766 (Testudines, Cheloniidae) from Brazil. Comp Parasitol 82:155-157

White M, Boura L, Venizelos L (2013) Population structure for sea turtles at Drini Bay: an important nearshore foraging and developmental habitat in Albania. Chelonian Conserv Biol 12:283-292

White MP, Pahl S, Wheeler BW, Fleming LEF, Depledge MH (2016) The 'Blue Gym': What can blue space do for you and what can you do for blue space? J Mar Biol Assoc UK 96:5-12

Whiting SD, Whiting AU (2011) Predation by the saltwater crocodile (Crocodylus porosus) on sea turtle adults, eggs, and hatchlings. Chelonian Conserv Biol 10:198-205

*Whiting AU, Chaloupka M, Limpus CJ (2013) Comparing sampling effort and errors in abundance estimates between short and protracted nesting seasons for sea turtles. J Exp Mar Biol Ecol 449:165-170

Whiting AU, Chaloupka M, Pilcher N, Basintal P, Limpus CJ (2014a) Comparison and review of models describing sea turtle nesting abundance. Mar Ecol Prog Ser 508:233-246

Whiting SD, Guinea ML, Fomiatti K, Flint M, Limpus CJ (2014b) Plasma biochemical and PCV ranges for healthy, wild, immature hawksbill (Eretmochelys imbricata) sea turtles. Vet Rec 174:608

WWittock PA, Pendoley KL, Hamann M (2014) Inter-nesting distribution of flatback turtles Natator depressus and industrial development in Western Australia. Endang Species Res 26:25-38

Wibbels T (2003) Critical approaches to sex determination in sea turtles. In: Lutz PL, Musick JA, Wyneken J (eds) The biology of sea turtles, Vol II. CRC Press, Boca Raton, FL, p 103-113

Wilcox C, Hardesty BD, Sharples R, Griffin DA, Lawson TJ, Gunn R (2013) Ghostnet impacts on globally threatened turtles, a spatial risk analysis for northern Australia. Conserv Lett 6:247-254

Wilcox C, Heathcote G, Goldberg J, Gunn R, Peel D, Hardesty BD (2015) Understanding the sources and effects of abandoned, lost, and discarded fishing gear on marine turtles in northern Australia. Conserv Biol 29:198-206

*Williams JL, Pierce SJ, Fuentes MMPB, Hamann M (2015) Effectiveness of recreational divers for monitoring sea turtle populations. Endang Species Res 26:209-219

Willis-Norton E, Hazen EL, Fossette S, Shillinger G and others (2015) Climate change impacts on leatherback turtle pelagic habitat in the Southeast Pacific. Deep-Sea Res II 113:260-267

Wise SS, Xie H, Fukuda T, Thompson WD, Wise JP (2014) Hexavalent chromium is cytotoxic and genotoxic to hawksbill sea turtle cells. Toxicol Appl Pharmacol 279: 113-118

* Witherington B, Hirama S, Mosier A (2011) Barriers to sea turtle nesting on Florida (USA) beaches: linear extent. J Coast Res 27:450-458

Wolanski E (in press) Bounded and unbounded boundaries - untangling mechanisms for estuarine-marine ecological connectivity: scales of $\mathrm{m}$ to $10,000 \mathrm{~km}$ - a review. 
Estuar Coast Mar Sci

Wood A, Booth DT, Limpus CJ (2014) Sun exposure, nest temperature and loggerhead turtle hatchlings: implications for beach shading management strategies at sea turtle rookeries. J Exp Mar Biol Ecol 451:105-114

Woolgar L, Trocini S, Mitchell N (2013) Key parameters describing temperature-dependent sex determination in the southernmost population of loggerhead sea turtles. J Exp Mar Biol Ecol 449:77-84

Work TM, Balazs GH, Summers TM, Hapdei JR, Tagarino AP (2015a) Causes of mortality in green turtles from Hawaii and the insular Pacific exclusive of fibropapillomatosis. Dis Aquat Org 115:103-110

Work TM, Dagenais J, Balazs GH, Schettle N, Ackermann M (2015b) Dynamics of virus shedding and in-situ confirmation of chelonid herpesvirus 5 in Hawaiian green turtles with fibropapillomatosis. Vet Pathol 52:1195-1201

Wright LI, Fuller WJ, Godley BJ, McGowan A, Tregenza T, Broderick AC (2012) Reconstruction of paternal genotypes over multiple breeding seasons reveals male green turtles do not breed annually. Mol Ecol 21:3625-3635

*Wyneken J, Lolavar A (2015) Loggerhead sea turtle environmental sex determination: implications of moisture and temperature for climate change based predictions for species survival. J Exp Zool B Mol Dev Evol 324:295-314

Xia ZR, Li PP, Gu HX, Fong JJ and others (2011) Evaluating noninvasive methods of sex identification in green sea turtle (Chelonia mydas) hatchlings. Chelonian Conserv Biol 10:117-123

Yamamoto KH, Powell RL, Anderson S, Sutton PC (2012) Using LiDAR to quantify topographic and bathymetric details for sea turtle nesting beaches in Florida. Remote Sens Environ 125:125-133

Yamamoto KH, Anderson SJ, Sutton PC (2015) Measuring the effects of morphological changes to sea turtle nesting beaches over time with LiDAR data. J Sea Res 104:9-15 *Yang W, Wang Y, Chen M (2015) Genetic structure and diversity of green sea turtle (Chelonia mydas) from South China Sea inferred by mtDNA control region sequence. Biochem Syst Ecol 60:95-98

* Young JL, Wise SS, Xie H, Zhu C, Fukuda T, Wise JP (2015) Comparative cytotoxicity and genotoxicity of soluble and particulate hexavalent chromium in human and hawksbill sea turtle (Eretmochelys imbricata) skin cells. Comp Biochem Physiol C Toxicol Pharmacol 178:145-155

Zarate PM, Bjorndal KA, Seminoff JA, Dutton PH, Bolten AB (2015) Somatic growth rates of green turtles (Chelonia mydas) and hawksbills (Eretmochelys imbricata) in the Galapagos Islands. J Herpetol 49:641-648

Kavala-Norzagaray AA, Alonso Aguirre A, VelazquezRoman J, Flores-Villasenor H and others (2015) Isolation, characterization, and antibiotic resistance of Vibrio spp. in sea turtles from Northwestern Mexico. Front Microbiol 6:635

Z Zbinden JA, Bearhop S, Bradshaw P, Gill B, Margaritoulis D, Newton J, Godley BJ (2011) Migratory dichotomy and associated phenotypic variation in marine turtles revealed by satellite tracking and stable isotope analysis. Mar Ecol Prog Ser 421:291-302

Zug GR, Kalb HJ, Luzar SJ (1997) Age and growth in wild Kemp's ridley sea turtles Lepidochelys kempii from skeletochronological data. Biol Conserv 80:261-268

* Zwarg T, Rossi S, Sanches TC, Cesar MD, Werneck MR, Matushima ER (2014) Hematological and histopathological evaluation of wildlife green turtles (Chelonia mydas) with and without fibropapilloma from the north coast of Sao Paulo state, Brazil. Pesqui Odontol Bras 34: 682-688 
Appendix 1. Scientific literature (details below table) published in 2014 and 2015 that address the 20 questions highlighted by Hamann et al. (2010)

\begin{tabular}{|c|c|c|}
\hline \multicolumn{2}{|c|}{ Question } & \multirow{2}{*}{$\begin{array}{l}\text { References } \\
1-9\end{array}$} \\
\hline 1 & $\begin{array}{l}\text { What are the factors that underpin nest site selection and behav- } \\
\text { iour of nesting turtles? }\end{array}$ & \\
\hline 2 & $\begin{array}{l}\text { What are the primary sex ratios being produced and how do these } \\
\text { vary within or among populations and species? }\end{array}$ & $10-21$ \\
\hline 3 & What factors are important for sustained hatchling production? & $8,14,15,18,19,21-41,[42],[43]$ \\
\hline 4 & $\begin{array}{l}\text { What are the population boundaries and connections that exist } \\
\text { among rookeries and foraging grounds? }\end{array}$ & $44-101$ \\
\hline 5 & $\begin{array}{l}\text { What parameters influence the biogeography of sea turtles in the } \\
\text { oceanic realm? }\end{array}$ & $48,51-53,70,71,79,82,85,87,88,91,102-117$ \\
\hline 6 & Where are key foraging habitats? & $\begin{array}{l}45,46,49,58,60-62,70,71,73,80-84,96,99 \\
103,104,108,117-133\end{array}$ \\
\hline 7 & $\begin{array}{l}\text { Can we develop methods to accurately age individual turtles, } \\
\text { determine a population's (or species') mean age-at-maturity, and } \\
\text { define age-based demography? }\end{array}$ & $111,134-145$ \\
\hline 8 & $\begin{array}{l}\text { What are the most reliable methods for estimating demographic } \\
\text { parameters? }\end{array}$ & $25,42,59,98,112,121,131,134-138,140,146-165$ \\
\hline 9 & $\begin{array}{l}\text { How can we develop an understanding of sea turtle metapopula- } \\
\text { tion dynamics and conservation biogeography? }\end{array}$ & $\begin{array}{l}44,48-50,52-57,59-63,65-69,72-78,80,81 \\
83-90,92-95,97,98,100,101,116,137,142,145 \\
151,159,160,166-174\end{array}$ \\
\hline 10 & What are the past and present roles of sea turtles in the ecosystem? & $175-182$ \\
\hline 11 & What constitutes a healthy turtle? & $183-229$ \\
\hline 12 & $\begin{array}{l}\text { What will be the impacts from climate change on sea turtles and } \\
\text { how can these be mitigated? }\end{array}$ & $\begin{array}{l}5,10,11,14,18,19,21,28-30,35,39,82,110,117 \\
166,230-248\end{array}$ \\
\hline 13 & $\begin{array}{l}\text { What are the major sources of fisheries bycatch and how can these } \\
\text { be mitigated in ways that are ecologically, economically and } \\
\text { socially practicable? }\end{array}$ & $58,64,82,96,102,106,181,249-285$ \\
\hline 14 & $\begin{array}{l}\text { How can we evaluate the effects of anthropogenic factors on sea } \\
\text { turtle habitats? }\end{array}$ & 246,286 \\
\hline 15 & What are the impacts of pollution on sea turtles and their habitats? & $196,197,217,287-311$ \\
\hline 16 & $\begin{array}{l}\text { What are the etiology and epidemiology of fibropapillomatosis (FP), } \\
\text { and how can this disease be managed? }\end{array}$ & $\begin{array}{l}183-185,193,197,207-209,212,227,229,297 \\
312-314\end{array}$ \\
\hline 17 & $\begin{array}{l}\text { How can we effectively determine the conservation status of sea } \\
\text { turtle populations? }\end{array}$ & $47,62,81,97,112,147,149,150,164,165,315-320$ \\
\hline 18 & $\begin{array}{l}\text { What are the most viable cultural, legal and socioeconomic } \\
\text { frameworks for sea turtle conservation? }\end{array}$ & $\begin{array}{l}97,175,250,259,264,266,269,279,283,285 \\
317,319,321-337\end{array}$ \\
\hline & $\begin{array}{l}\text { Which conservation strategies are working (have worked) and } \\
\text { which have failed? }\end{array}$ & $\begin{array}{l}22,26,32,47,67,97,149,164,236,239,266,277 \\
278,316,317,319,321,323,324,326,329 \\
331,335,336,338-353\end{array}$ \\
\hline & $\begin{array}{l}\text { Under what conditions (ecological, environmental, social and } \\
\text { political) can consumptive use of sea turtles be sustained? }\end{array}$ & $\begin{array}{l}69,97,250,266,277,316,319,322,324,327,331 \\
336,341,354,355\end{array}$ \\
\hline
\end{tabular}

1. Anastácio et al. (2014)

2. Barik et al. (2014)

3. Brothers \& Lohmann (2015)

4. Kawazu et al. (2015a)

5. Lamont \& Fujisaki (2014)

6. Lamont \& Houser (2014)

7. Neeman et al. (2015a)

8. Reising et al. (2015)

9. Whittock et al. (2014)

10. Girondot \& Kaska (2014)

11. Girondot \& Kaska (2015)

12. Jribi \& Bradai (2014)

13. Kilic \& Candan (2014)

14. Laloë et al. (2014)

15. Lolavar \& Wyneken (2015)

16. dei Marcovaldi et al. (2014)

17. Morales Mérida et al. (2015)
18. Santidrián Tomillo et al. (2015a) 35. Pike (2014)

19. Santidrián Tomillo et al. (2014) 36. Prieto-Torres \& Hernandez-

20. Simoes et al. (2014)

21. Wyneken \& Lolavar (2015)

22. Abd Mutalib \& Fadzly (2015)

23. Bevan et al. (2014)

24. Bézy et al. (2015)

25. Brost et al. (2015)

26. Burger \& Gochfeld (2014)

27. Dellert et al. (2014)

28. Dudley \& Porter (2014)

29. Howard et al. (2014)

30. Howard et al. (2015)

31. Cheng et al. (2015)

32. Mcelroy et al. (2015)

33. Phillips et al. (2014b)

34. Phillott \& Parmenter (2014)

\section{Rangel (2015).}

37. Rafferty \& Reina (2014)

38. Rings et al. (2015)

39. Santidrián Tomillo et al. (2015b)

40. Sarmiento-Ramírez et al. (2014a)

41. Sarmiento-Ramírez et al. (2014b)

42. Alfaro-Núñez et al. (2015)

43. Baena et al. (2015)

44. Al-Mohanna et al. (2014)

45. Attum et al. (2014)

46. Baudouin et al. (2015)

47. Bourjea et al. (2015b)

48. Bourjea et al. (2015a)

49. Carreras et al. (2014a)

50. Carreras et al. (2014b)
51. Casale \& Mariani (2014)

52. Clusa et al. (2014)

53. Dalleau et al. (2014)

54. Daza-Criado \& Hernandez-

Fernandez (2014)

55. Detjen et al. (2015)

56. Dutton et al. (2014a)

57. Esteban et al. (2015)

58. Fossette et al. (2014)

59. Frey et al. (2014)

60. Fujioka \& Halpin (2014)

61. Gorham et al. (2014)

62. Gredzens et al. (2014)

63. Hamabata et al. (2014)

64. Hardy et al. (2014)

65. Hart et al. (2015)

66. Hart et al. (2014) 
67. Hays et al. (2014b)

68. Jordão et al. (2015)

69. Joseph Jet al. (2014)

70. Lamont et al. (2015)

71. Luschi \& Casale (2014)

72. Meylan et al. (2014)

73. Narazaki et al. (2015)

74. Naro-Maciel et al. (2014a)

75. Naro-Maciel et al. (2014b)

76. $\mathrm{Ng}$ et al. (2014)

77. Nishizawa et al. (2014a)

78. Nishizawa et al. (2014b)

79. Patel et al. (2015a)

80. Patel et al. (2015b)

81. Pendoley et al. (2014b)

82. Pikesley et al. (2015)

83. Pilcher et al. (2014)

84. Plot et al. (2015)

85. Proietti et al. (2014b)

86. Prosdocimi et al. (2015)

87. Prosdocimi et al. (2014)

88. Putman et al. (2014)

89. Read et al. (2014)

90. Saito et al. (2015)

91. Scott et al. (2014b)

92. Shamblin et al. (2015a)

93. Shamblin et al. (2015c)

94. Shamblin et al. (2014)

95. Shamblin et al. (2015b)

96. Stokes et al. (2015)

97. Stringell et al. (2015a)

98. Tedeschi et al. (2014)

99. Tucker et al. (2014)

100. Vander Zanden et al. (2015)

101. Yang et al. (2015

102. Bhatpuria et al. (2015)

103. Dodge et al. (2014)

104. Fujioka et al. (2014b)

105. González Carman et el. (2014b)

106. Howell et al. (2015)

107. Kobayashi et al. (2014)

108. López-Castro et al. (2014b)

109. Mansfield et al. (2014)

110. Neeman et al. (2015b)

111. Ramirez et al. (2015)

112. Robinson et al. (2014)

113. Scales et al. (2014)

114. Scales et al. (2015)

115. Scott et al. (2014a)

116. Wallace et al. (2014)

117. Willis-Norton et al. (2015)

118. Bovery \& Wyneken (2015)

119. Cardona et al. (2014)

120. Ceriani et al. (2015)

121. Colman et al. (2015)

122. Foley et al. (2014)

123. Fuentes et al. (2015a)

124. Fukuoka et al. (2015)

125. Prior et al. (2015)

126. Putman \& Mansfield (2015)

127. Putman etal. (2015b)

128. Sampson et al. (2014)

129. Seminoff et al. (2014)

130. Stadler et al. (2015)

131. Vander Zanden et al. (2014)

132. Velez-Zuazo et al. (2014)

133. Walcott et al. (2014)

134. Avens et al. (2015)

135. Balazs et al. (2015a).

136. Bjorndal et al. (2014)

137. Casale et al. (2015)

138. Hawkes et al. (2014)

139. Kawazu et al. (2015b)
140. Petitet et al. (2015)

141. Quinones et al. (2015)

142. Turner Tomaszewicz et al. (2015)

143. Tucek et al. (2014)

144. Van Houtan et al. (2014a)

145. Zarate et al. (2015)

146. Allen et al. (2015)

147. Delcroix et al. (2014)

148. Derville et al. (2015)

149. García-Cruz et al. (2015)

150. Girondot \& Rizzo (2015)

151. Grego \& Hitchcock (2014)

152. Goodman Hall et al. (2015)

153. Lamont et al. (2014)

154. LeBlanc et al. (2014)

155. López-Castro et al. (2014a)

156. Patrício et al. (2014)

157. Pendoley et al. (2014a)

158. Phillips et al. (2014a)

159. Phillips et al. (2014c)

160. Pilcher et al. (2015)

161. Shimada et al. (2014)

162. Stewart \& Dutton (2014)

163. Stewart et al. (2014)

164. Stokes et al. (2014)

165. Whiting et al. (2014a)

166. Boyle et al. (2014)

167. Caillouet (2014)

168. Casale et al. (2014)

169. Duran et al. (2015)

170. González-Garza et al. (2015)

171. Hamabata et al. (2015)

172. Labrada-Martagón et

173. Proietti et al. (2014a)

174. Trujillo-Ariaset al. (2014)

175. Viet Anh et al. (2014)

176. Cardona et al. (2015)

177. Christianen et al. (2014)

178. Guilder et al. (2015)

179. Lacey et al. (2014)

180. Molina Hernández et al. (2014)

181. Piroddi et al. (2015)

182. Santos et al. (2015b)

183. Alfaro-Núñez et al. (2014)

184. Alfaro-Núñez \& Gilbert (2014)

185. Deus Santos et al. (2015)

186. Fernandez et al. (2015)

187. Flint et al. (2015b)

188. Flint et al. (2015a)

189. Flower et al. (2015)

190. Fonseca et al. (2015)

191. García-Párraga et al. (2014)

192. Hill et al. (2014)

193. Hirama et al. (2014)

194. Innis et al. (2014)

195. Isler et al. (2014)

196. Jin et al. (2015)

197. Keller et al. (2014)

198. Kelly et al. (2015)

199. Levy et al. (2014)

200. Lewbart et al. (2014)

201. Li et al. (2015)

202. McFadden et al. (2014)

203. Montilla et al. (2014)

204. Muñoz et al. (2014)

205. Nardini et al. (2014)

206. Norton et al. (2015)

207. Page-Karjian et al. (2015a)

208. Page-Karjian et al. (2014)

209. Page-Karjian et al. (2015b)

210. Perrault et al. (2014)

211. Rocha et al. (2015)
212. Rodenbusch et al. (2014)

213. Ruggiero et al. (2014)

214. Santoro et al. (2015)

215. Schumacher et al. (2014)

216. Stacy et al. (2015)

217. Storelli \& Zizzo (2014)

218. Villa et al. (2015)

219. Werneck et al. (2014)

220. Werneck et al. (2015a)

221. Werneck et al. (2015b)

222. Werneck \& Silva (2015)

223. Werneck et al. (2015d)

224. Werneck et al.(2015c)

225. Whiting et al. (2014b)

226. Work et al. (2015a)

227. Work et al. (2015b)

228. Zavala-Norzagaray

29. Zwarg et al. (2014)

230. Calvillo Garcia et al. (2015)

231. Cavallo et al. (2015)

232. Dewald \& Pike (2014)

233. Fisher et al. (2014)

234. Hill et al. (2015b)

235. Horne et al. (2014)

236. Jourdan \& Fuentes (2015)

237. Katselidis et al. (2014)

238. Kumar et al. (2014)

239. Lopez (2015)

240. Mazaris et al. (2015)

241. Neeman et al. (2015c)

242. Osorio A et al. (2014)

243. Patino-Martinez et al. (2014)

244. Sim et al. (2015)

245. Tedeschi et al. (2015)

246. Thomson et al. (2015a)

247. Wood et al. (2014)

248. Yamamoto et al. (2015)

249. Adimey et al. (2014)

250. Aguilar-González et al. (2014)

251. Álvarez de Quevedo et al. (2014

252. Amorim et al. (2015)

. Ayala \& Sanchez-Scaglioni (2014)

254. Ayissi et al. (2015)

255. Báez et al. (2014b)

256. Bostwick et al. (2014)

257. Bourjea et al. (2014)

258. Báez et al. (2014a)

259. Christie et al. (2014)

260. Coelho et al. (2015)

261. Curtis et al. (2015b)

262. Curtis et al. (2015a)

263. Domènech et al. (2015)

264. Gilman et al. (2014)

265. Girard et al. (2014)

266. Gjertsen et al. (2014)

267. Huang (2015b)

268. Huang(2015a)

269. Kvamsdal \& Stohs (2014)

270. Levy et al. (2015)

271. Lewison et al. (2014)

272. Martin et al. (2015a)

273. Murray (2015)

274. Parga et al. (2015)

275. Pelc et al. (2015)

276. Roe et al. (2014)

277. Senko et al. (2014a)

278. Senko et al. (2014b)

279. Singh \& Weninger(2015)

280. Swimmer et al. (2014)

281. Tamura et al. (2014)

282. Tanner (2014)

283. Teh et al. (2015)

284. Warden et al. (2015)

285. Watson \& Bigelow (2014)

286. Flores-Monter et al. (2015)

287. Barreiros \& Raykov (2014)

288. Bucchia et al. (2015)

289. Camedda et al. (2014)

290. de Carvalho et al. (2015)

291. Deudero \& Alomar (2015)

292. Gómez-Picos et al. (2014)

293. González Carman et al. (2014a)

294. Hoarau et al. (2014)

295. Kamrowski et al. (2014a)

296. Kamrowski et al. (2014c)

297. McCrink-Goode (2014)

298. da Silva Mendes et al. (2015)

299. Pendoley \& Kamrowski (2015)

300. Poli et al. (2014)

301. Poli et al. (2015)

302. Putman et al. (2015a)

303. Reinhold (2015)

304. Reintsma et al. (2014)

305. Rivas et al. (2015)

306. Robinson \& Figgener (2015)

307. Santos et al. (2015a)

308. Schuyler et al. (2014b)

309. Schuyler et al. (2014a)

310. Sigler (2014)

311. Wilcox et al. (2015)

312. Rossi et al. (2015)

313. Sellera et al. (2104)

314. Van Houtan et al. (2014b)

315. Ehrhart et al. (2014)

316. Hamilton et al. (2015)

317. Jackson et al. (2015)

318. Metcalfe et al. (2015)

319. Van Houtan \& Kittinger (2014)

320. Weber et al. (2014)

321. Fuentes et al. (2015b)

322. Halkyard (2014)

. Harris et al. (2015)

24. Hill et al. (2015a)

325. Humber et al. (2015)

326. Kamrowski et al. (2014b)

327. Lagueux et al. (2014)

328. Lascelles et al. (2014)

329. Lewison et al. (2015)

330. Lopez et al. (2015)

331. Macrae \& Whiting (2014)

332. Martin et al. (2015b)

333. Maxwell et al. (2015)

334. Mazaris et al. (2014)

335. McDonald et al. (2014)

336. Tisdell \& Tisdell (2014a)

337. Tisdell \& Tisdell (2014b)

338. Baker et al. (2015)

339. Balazs et al. (2015b)

340. Caillouet et al. (2015)

341. Humber et al. (2014)

342. Lamarre-DeJesus \& Griffin (2015)

343. Mestre et al. (2014)

344. Nijman (2015)

345. Revuelta et al. (2015a)

346. Revuelta et al. (2014)

347. Revuelta et al. (2015b)

348. Schneller \& Irizarry (2014)

349. Schofield et al. (2015)

350. Shaver \& Caillouet (2015)

351. Tisdell \& Tisdell (2014c)

352. Ullmann \& Stachowitsch (2015)

353. Walcott \& Horrocks (2014) 